TUSSUR SILK $B Y$ THOMAS WARDLE 


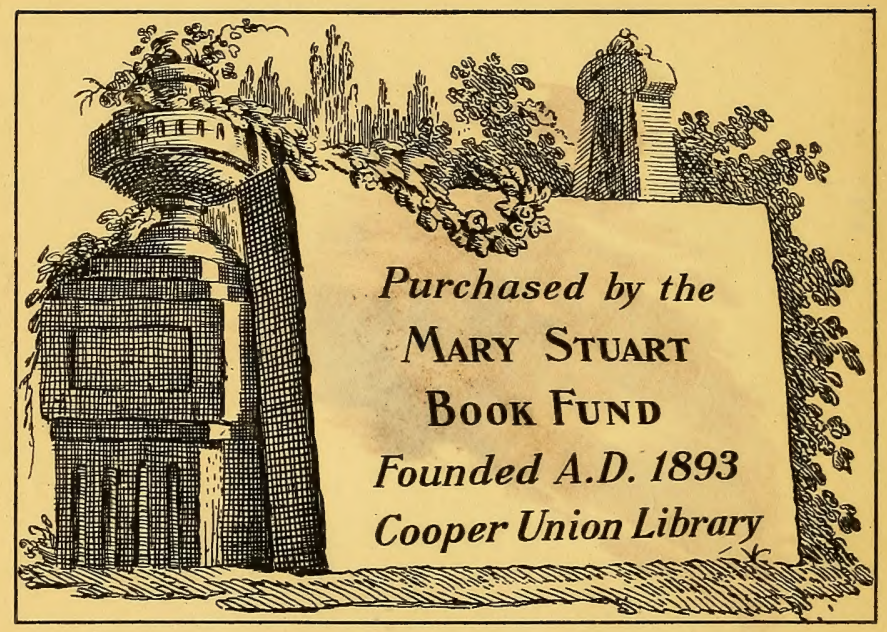




$$
\text { C N Dastio } 8
$$


T化 


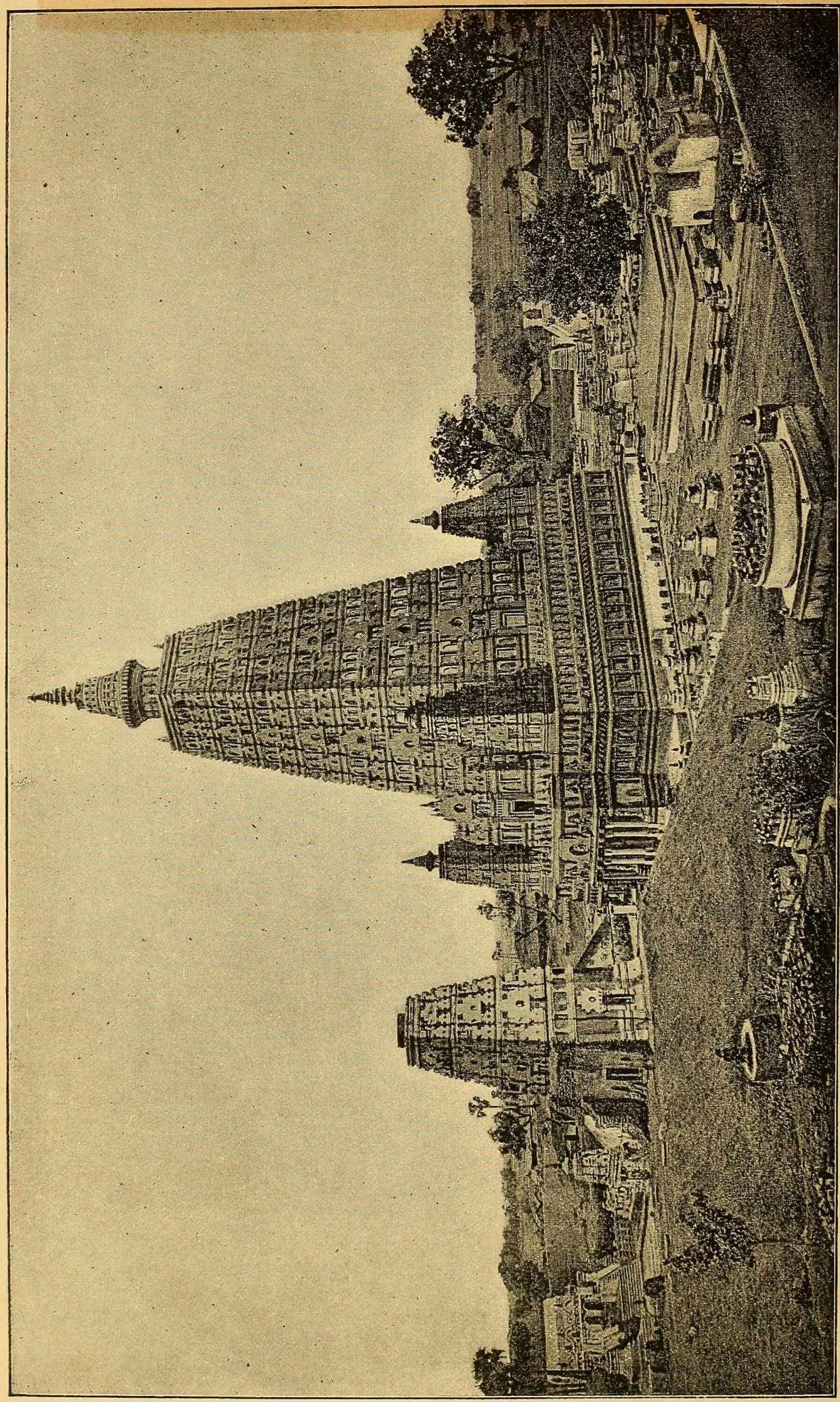

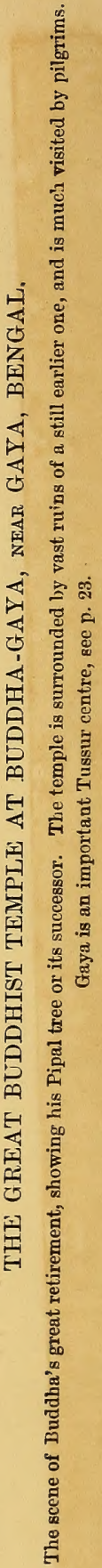


SIR THOMAS WARDLE, J.P., F.G.S., F.C.S.,

\author{
ON THE
}

HISTORY AND GROWING UTILISATIONS

$\mathrm{OF}$

\title{
TUSSUR SILK.
}

A PAPER READ AT THE SOCIETY OF ARTS on MAY 14TH, 1891,

BY

\section{THOMAS WARDLE,}

Feliow of the Chemical Society; Fellow of the Geological Society; Member of Councic of the

Palcontographical Society; Chevalier de la Legion d'Honneur of France; Officier

d'Academie of France; Membre du Jury de l'Industrie de la Soie a l' Expositions

Universelles d Paris, 1878 and 1889; Honorary Superintendent of the

Indian Silk Culture Court of the Colonial and Indian Fxhibition,

London, 1880; Chairman of the Sitl Section of the Royal

Jubitee Exhibition, Manchester, 1887;

One of the Examiners to the City and Guilds of London Institute;

President of the Silk Association of Great Britain and Ireland;

President of the North Staffordshire Field Nuturalists' Club and Archaogical Society, \&c.

Reprinted from the "Journal of the Society of Arts," June 12, 1891.

LONDON :

PRINTED BY W. TROUNCE, 10, GOUGH-SQUARE, FLEET-STREET, LONION, li.( 


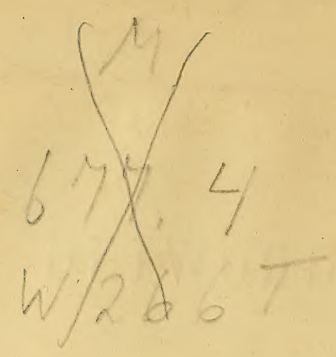

1

316899

AUG 251953 


\section{HISTORY AND GROWING UTILISATIONS OF TUSSUR SILK.}

The principal objects of this paper are to place upon record the progress of the utilisation of tussur silk, and to give some account of its history.

Further details concerning its early history, and very limited uses prior to 1870 , will be found in my "South Kensington Museum Handbook of the Wild Silks of India," written at the close of the Paris Exhibition, at the request of Sir Philip Cunliffe-Owen, and in the paper which I had the honour to read before this Society in 1879 ; but it will be nevessary for me to treat at some length on a few points connected with its development, its properties, and structure ; and of the coun. tries and peoples from whom it is obtained, as they are subjects too closely interwoven with its present uses to be altogether omitted.

In the "Handbook of the Wild Silks of India," to which I have just referred, I quoted at length a paper from the Annual Report of the Government Central Museum at Bombay, written so early as I 860 , by Sir George (then Dr.) Birdwood, who was the first to call English attention to this silk, which he, at that early date, thought fitted to more refined

FIG I.

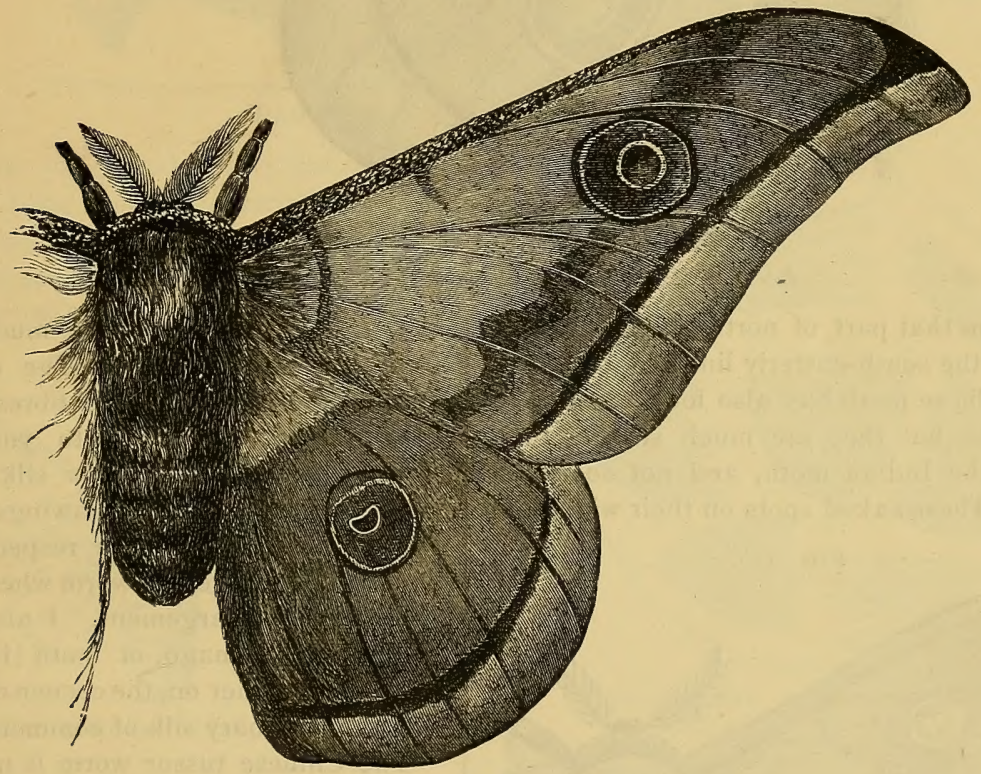

Anther fa Mylitta, or Tussur Moth, Male.

\$ manufacturing uses than it had received in India; and calling the attention of the Government to the importance of cultivating it on a more extended and enlightened scale in that courtry. The subjects discussed in this most interesting paper relate to the natural history of the silkworm, its iood-trees, mode of collection in various parts of India, the reeling of the cocoons, the rude dyeing of the silk, its manufacture into cloth, and also giving full references to the literature of the subject up to that time.

\section{India ANd China Tussur Silk.}

It would have been much more agreeable to me to have confined my paper to a description of the tussur silk of India, but, inasmuch as there are two kinds of tussur silk known to commerce-one Indian and the other Chinese - my treatment of the subject could not have been either so fair or so complete had I adopted this course. I propose, therefore, to speak of both kinds.

The Indian moth is distinguished, as you see, by four large, transparent, window-like wing spots, larger in the female than in the male, almost of the transparency of glass, surrounded by a purple circle.

The transparent wing spots on the tussur moth are regarded with superstitious reverence 
by the natives of India, who see in them a re- I by the finger-touches of Vishnu, and the moth semblance to the chakra or discus of the god Vishnu, and from this they consider the moth sacred. In other parts of India these spots are considered to have been originally caused

is there also regarded as a sacred insect.

China tussur silk is the product of the larve or caterpillar of the moth known to entomologists by the name of Anthercea pernyi, and

FIG. 2.

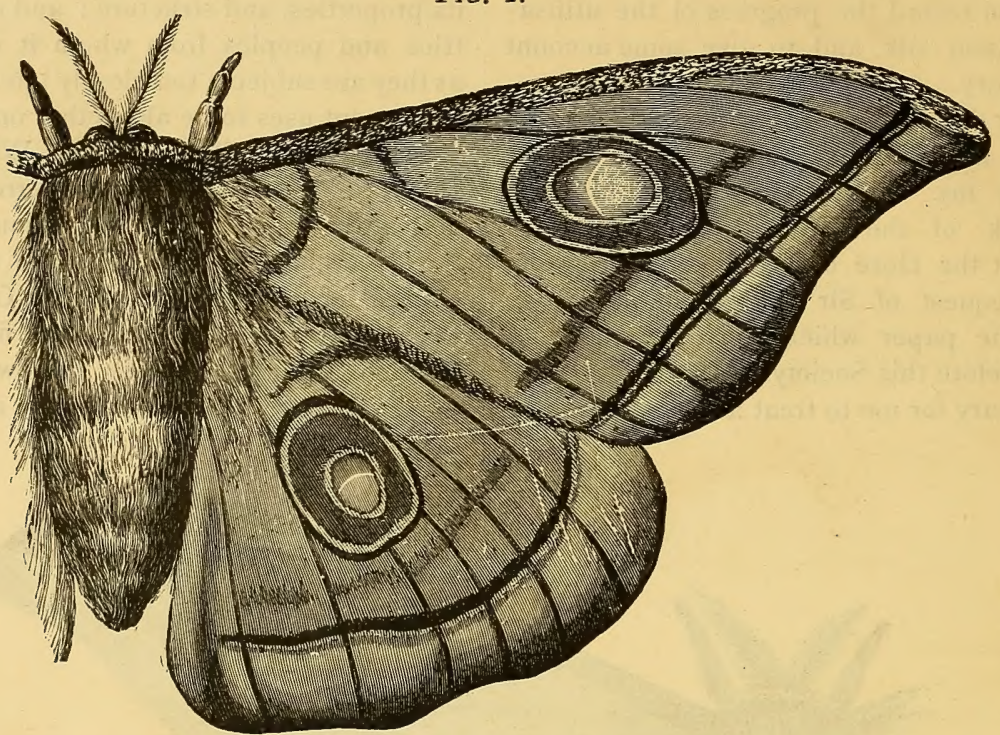

Antherfa Mylitta, or Tussur Moth, Jiemale.

comes from that part of north China of which Chefoo is the south-easterly limit.

The Chinese moth has also four transparent wing spots, but they are much smaller than those in the Indian moth, and not so transparent. These naked spots on their wings are FIG. 3.

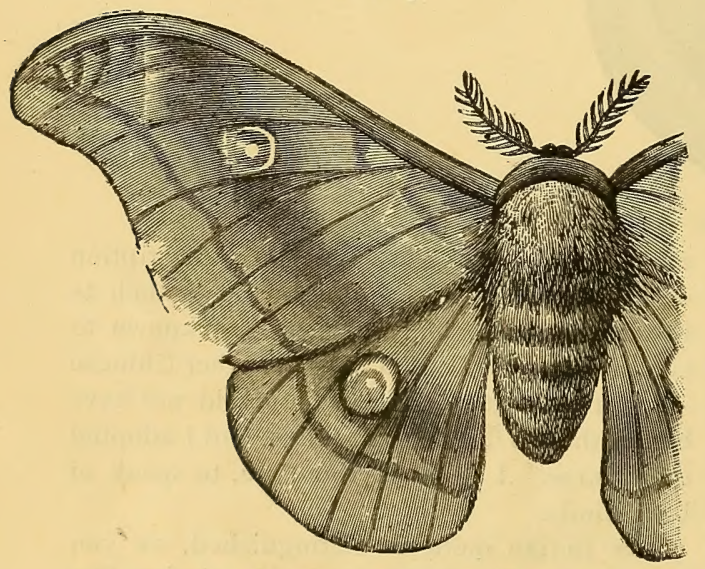

Anthera Pernyi, Male.

a consequence of the entire absence of the wing scales, which entirely cover the whole of the other parts of their wings.

The Chinese tussur moth differs much in appearance and also very much in colour from the Indian moth. The microscopical structure of the ultimate fibres also differs considerably. I present to your notice the larvæ, moths, cocoons, raw silk reeled from the cocoons, and also drawings of them, as well as drawings of their respective fibres as seriposited by the silkworm when seen under microscopic enlargement. I also add figures of the larva, imago, or moth (Figs. 4 and 5, p. 5) and, further on, the cocoon of the Bombyx mori, or ordinary silk of commerce.

The Chinese tussur worm is more insignifcant in appearance than the Indian, which is arrayed in a glorious mantle of green. It is also a much plainer one than the Indian, and considerably smaller.

This caterpillar feeds on the leaves of the oak, and it is different in appearance, habits, and colour from the other tussur silkworm, of which I purposely intend to speak at greater length, and for this important reason, that, as it abounds and flourishes in our great dependency of India, it is on that account more interesting to us than the Chinese tussur, and, for the sake of the people of that great country, it is my main purpose to-day to demonstrate that we should do our best to see its production stimulated there, and also greatly increased. 
The dust-like-particles, which are removed by the finger when the wing of a butterfly or moth is touched, are revealed by the microscope to be perfectly-formed scales, more or lass of a triangular shape; plates pointed at the end of their attachment to the wing membrane, and widening out at the broad extremities of their lengths into serrated edges, as in the case of Anthercea mylitta, or long digitate processes, as in the Bombyx mori, FIG. 4.

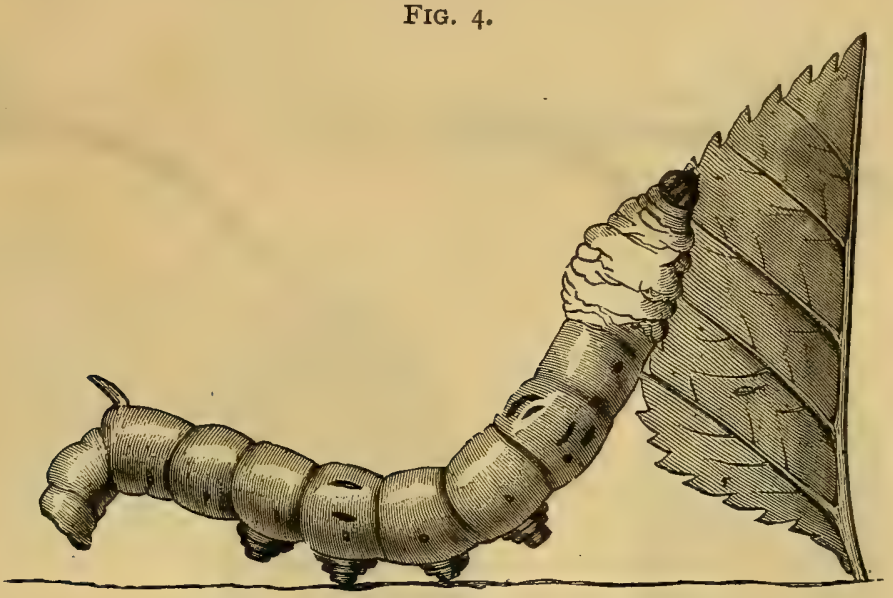

LARVA OF BOMBYX MORI OF ITALY.

figured below. The scales vary considerably in size and shape; so characteristic are they in these respects, that it is almost possible to detect the species of the moth by a microscopic examination of them.

FIG. 5.

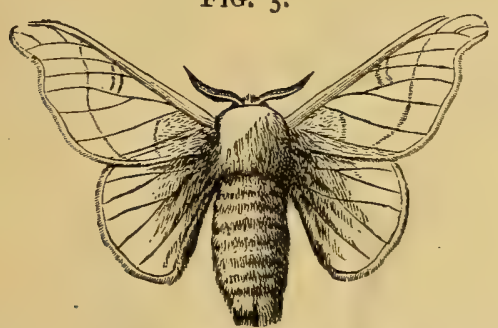

Bombyx Mori of Italy, Female.

The drawings, as in Figs. 6 and 7 , of two species will illustrate this. The wingscales, as they rest in situ on the moth's wing, overlap each other with the greatest precision and regularity, resembling an ornamentally tiled or slated roof.

\section{TUSSUR CoCOONS.}

There is much difference between Indian tussur cocoons and those of the Chinese worm.

The Indian cocoons are hard, well-formed, shell-like, and shaped like a pullet's egg, and very compact. They vary much in size, the average being about $1 \frac{3}{4}$ inches long, and ${ }^{1} \frac{1}{16}$ inches in diameter. the weight is about 16 grains. They possess pedicular attach-

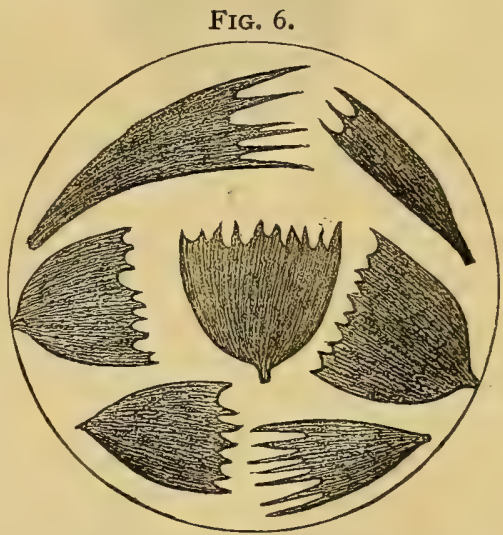

Wing Scales of the Tussur Moth. Antherea Mylitta.

\section{FIG. 7.}

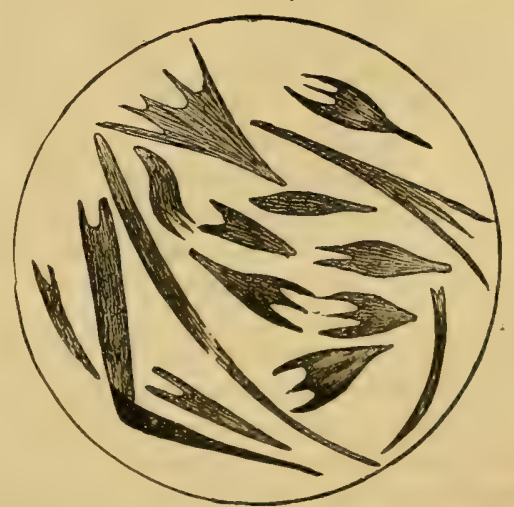

Wing SCAles of THE MUlberRy MOTH. BOMBYX MORI. 
ments, the nature and use of which I shall describe further on.

The forming of the Indian cocoon, and of its attached pedicle, is as follows:-
After the caterpillar has seriposited a few layers of silk thick enough to conceal itself, it extrudes a grumous kind of cementing matter, and by muscular action it causes this excretion

FIG. 8.

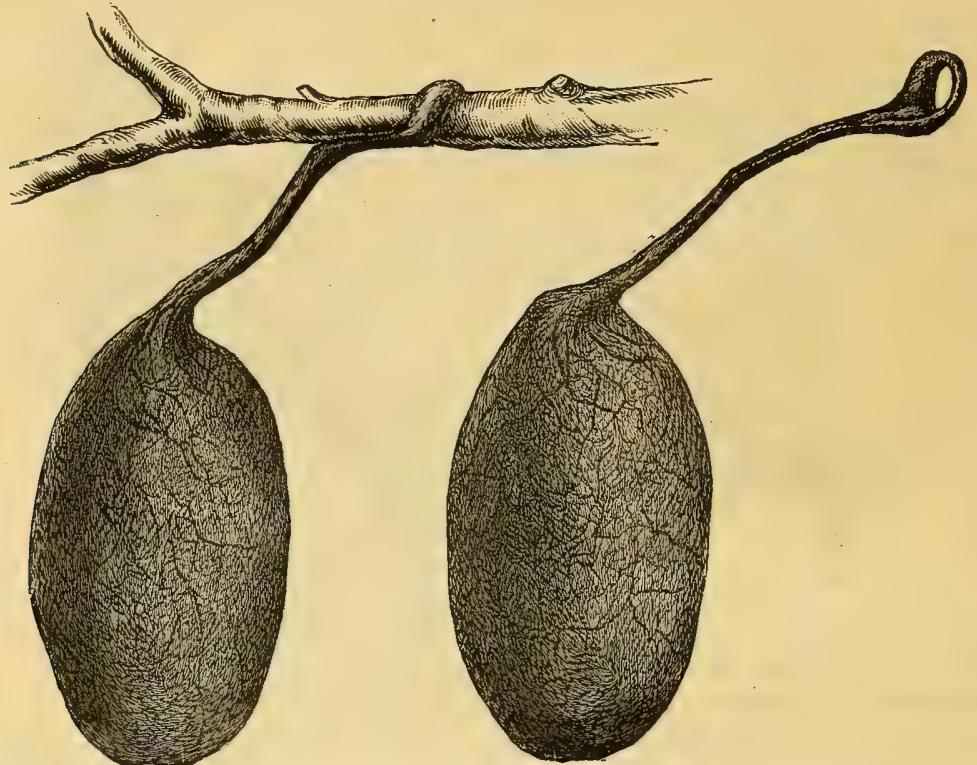

Tussur Cocuons with their Pedicles, showing Natural Attachment to Branches.

Intermittently to permeate the fibres, and gradually to solidify the cocoon wall. It thus goes on seripositing layer after layer of small loops of silk, and cementing them together, until the whole of its supply is exhausted ; the wall of the cocoon has then become so hard that it requires a sharp penknife to cut through it. The ring at the end of the pedicle, by which its attachment to the branch or twig is secured, and the pedicle itself, are most necessary provisions of nature, for should the caterpillar have begun to make its cocoon in attachment to a leaf only, as those species do which remain for a short time in the chrysalis state, it would fall with the leaf, and doubtless be destroyed by insects or animals; but the tussur chrysalis requires months for its serene and mysterious sleep, and by a marvellous instinct the caterpillar first entwines its silken thread hundreds of times round a branch or twig, and then lengthens this arrangement by seripositing the silken fluid so as to make a thick, tendon-like cord, at the end of which it forms its cocoon, the whole being a marvel of construction and beauty of form, as you see in the drawing, and in these attached cocoons which hang securely from the branches in a fruit-like manner.
After its time of probation in the pupa or chrysalis state, a moist spot is observed at one end of the cocoon. It is now about to emerge from its silken berth; it secretes an acid fluid FIG. 9.

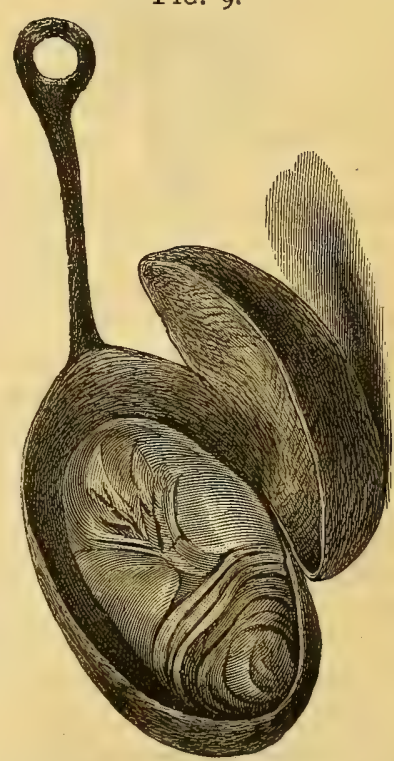

Shows Cocoon cut OPEN, WrTh Chrysalis INSIDE. 
which softens the cement of the cocoon, to enable it to separate the fibres sufficiently to allow of its creeping out, being assisted in this by its short pointed wing-spines.

The Chinese cocoon is soft, and has not much definite shape or consistency, being generally formed between two or three leaves of the oak trees on which the worm feeds. The Chinese tussur cocoon measures $I \frac{1}{2}$ inches in length, diameter $\frac{3}{4}$ of an inch, and weighs from 8 to 9 grains.

FIG. I0.

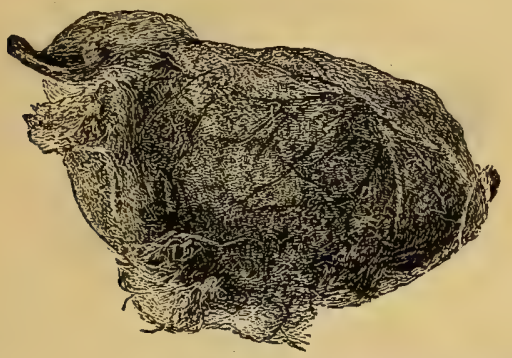

Chinese Tussur Cucoon, Antherea Pernyi.

There are many species of larvæ which produce silk. It is but a few years ago that it was generally thought there were only one or two kinds of silk, but in the Silk-Culture-court of the Colonial and Indian Exhibition, upwards of 59 species of silk-producing worms were shown, with the silk they produced; there were also live eggs, cocoons with living chrysalides, and moths of Anthercea mylitta, Anthercea Pernyi, Attacus ricini, Cricula trifenestrata, Samia cecropia, and a wingless species of an unnamed Psychidce of Senegal. Also another specimen of Psychidee from Ranchi, Chutia Nagpur, Bengal, the caterpillars of which feed on the tea plant.

The great beauty and variety of these living moths excited much attention, but it was left for the afterwork which took place between this Exhibition and that of the Manchester Jubilee Exhibition, to place upon record that a very large number of genera of the moth tribe make silken cocoons of more or less completeness, and in the Silk Section of that Exhibition I was able to show no fewer than 265 species of moths whose larvæ make cocoons; a number of which were exhibited alive in large glass cases in their various stages of existence.

They formed an exceedingly splendid and interesting menagerie of silk-producing Lepidoptera, to which many thousands of people were daily attracted. Their names are recorded and several of the species are figured in the illustrated catalogue of that Fxhibition.
Now it is of course well known that all the species have the same instinctive object in covering themselves with this silken envelope, namely, to protect themselves during that wonderful and all but lifeless' pupæ or chrysalide state, which, in the mysterious arrangement of their lives, they have for a time to undergo ; the caterpillar thus making for itself a veritable and wonderful tomb, from which in due time it rises again in the state of a beautiful and perfect winged insect. It is this silken chamber, which in the case of the Bombyx mori, has for so many centuries and decades of centuries been wound off into a continuous thread, dyed and woven into fabrics of such great charm, variety, and utility in India and the further East.

All species of silkworms have two stores of silk, one on each side of the alimentary canal ; and below their mouths they have two so-called spinnarets or orifices, to which I have ventured to give the name of "seripositors," through which the silk issues simultaneously in pairs of fine parallel filaments or fibres, forming, in fact, a double thread, which, on exposure to the air, immediately solidifies and becomes silk.

It is of the structure of the fibres of one of these species of silk, and of its growing uses, that I am here to-day to describe, and to report the remarkable progress which has supervened since the Paris Exhibition of 1878 , with regard to the great developments in the commercial and manufacturing utilization of tussur silk.

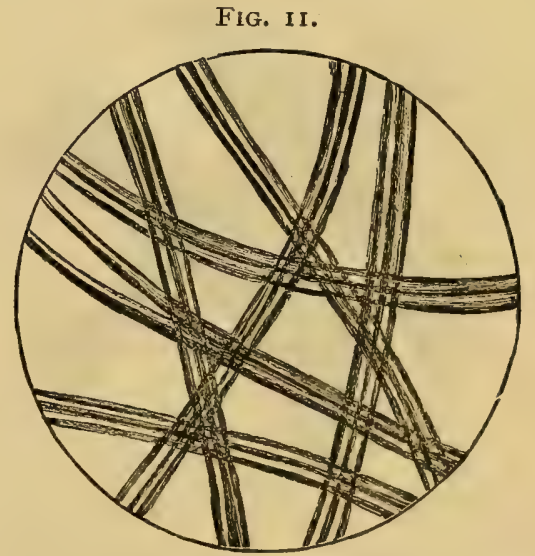

Fibres of Silk of Commerce, Bombyx Moki.

The differences in the fibre-structure of tussur silk from that of the ordinary silk of commerce, the product of the Bombyx mori silkworm is very considerable, and is shown in the drawings. 
Thus the fibre of the Bombyx mori is round and homogeneous, and resembles a glass rod, as shown in section, Fig. 12 ; that being the characteristic and structureless form of the silk of all of the Bombycida I have examined.

FIG. 12.

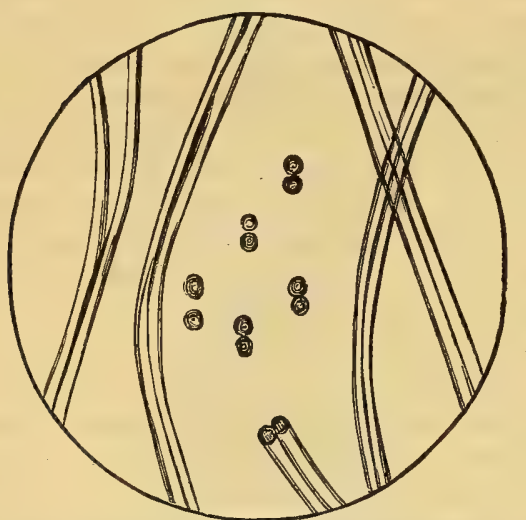

Silk of BOMbyx MORI OF COMMerce, SHOWIng also TRansverse Sections.

But the family Saturnide produce silk of another structure. In all the species of Saturnide known to me, the fibre is always more or less flat, as shown in the drawing, especially in tussur silk. Besides being flat, or tape-like, it possesses structure not unlike the appearance of the warp-threads stretched in a loom before being woven.

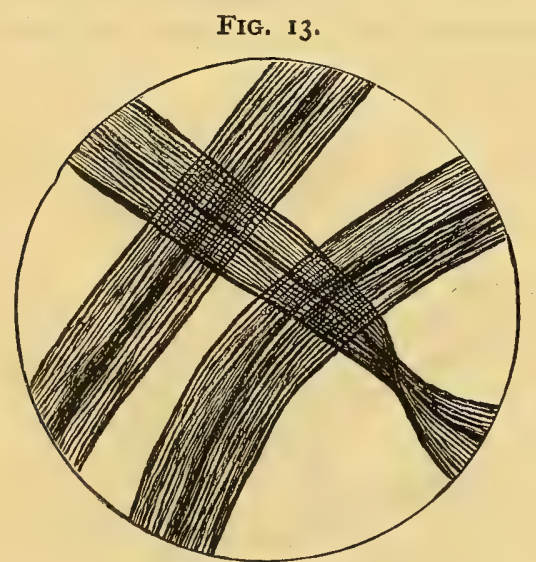

Silk DF ANThera MylitTa, OR Tussur Silk.

The width of the single or ultimate fibre of tussur silk is about the 75oth part of an inch, and in this narrow width there are about 20 smaller fibres or fibrillæ lying longitudinally, and connected with each other by a hardened fluid seriposited at the time the worm forms this silken thread. I have succeeded in isolating these fibrillæ by dissolving the hardened medium, with the result shown in the drawing and in Fig. 14. The fibrilla of the Chinese tussur fibres are finer and rather more numerous than in the tussur fibres, as seen in Fig. 15.

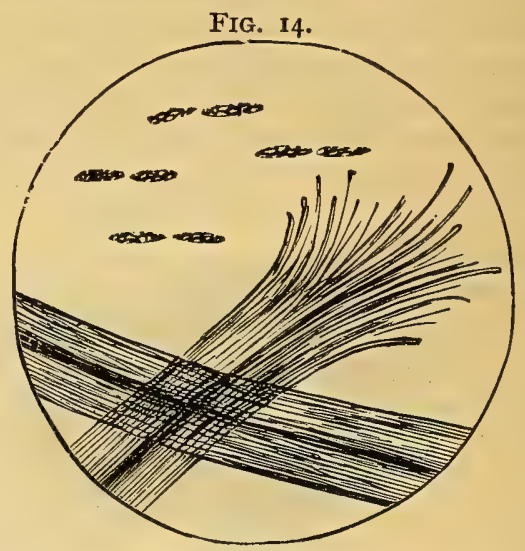

Silk of ANther ata Mrlitta, or Tussur SilkShowing SEParated Fibrill $A$ and Trans, VERSE SECTIONS.

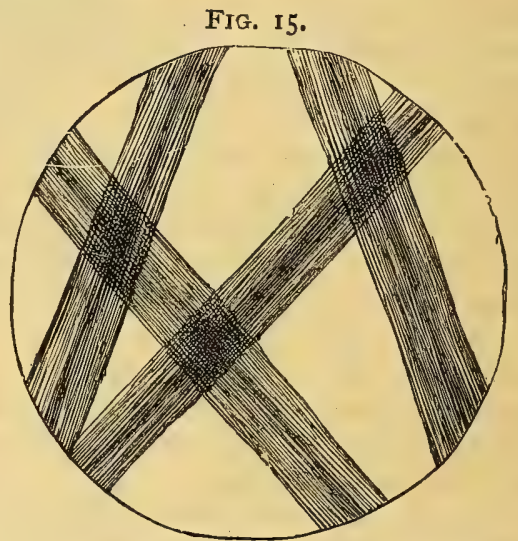

Silk of Antherea Pernyi, or Chinese TUSSUR SILR.

Cocoon Reeling.

The cocoon of the ordinary silkworm of commerce, the Bombyx mori, is soft, and when macerated in hot water the silk is easily drawn off; when reeled and manufactured into skeins

FIG. I6.

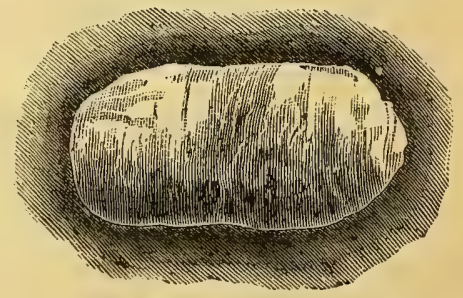

Cocoon of Bombyx Mori, Italian. 
it is easily dyed, owing to the homogeneous structure of its fibre, which absorbs the tinctorial matter with regularity, and, moreover, it has a chemical affinity for many kinds of dyes, tans and mordants.

In Tussur silk the opposite of this is the case. It can neither be reeled easily, nor, until recent years, could it be dyed without great difficulty, and by methods which, step by step, have at last succeeded,

With regard to the reeling, I was sent to Italy by the Government of India in 1874 , to try and find out a way of reeling Indian Tussur cocoons. Europeans had not at that time been able to soften these hard cocoons sufficiently to allow of a continuous thread being wound or reeled from them.

By the introduction of a friend, Mr. T. H. Gaddum, I obtained permission to visit one of the filatures in Piedmont, at St. Cio, near Torre Pellice. On arriving there $I$ found an extensive mulberry-silk reeling and throwing establishment, situated in a most beautiful valley, in one of the southern spurs of the Alps, about three hours journey north of Turin.

On explaining my mission, and showing the wild cocoons, I was told there was not much prospect of success, for several trials had been made, and they had been found difficult to soften and impractible to work. I asked to be allowed to try myself. The permission being generously granted, and every assistance kindly afforded me, I was taken to the reeling rnom, where about roo young women were at work, with well-trained fingers, reeling the small Piedmont cocoon of Bombyx mori. The operation was interesting in the extreme, heightened, as it was, by their strange singing of old French songs, in a dialect not understood by the Italians-a strange and all-butforgotten tongue-which has to be learned by the mill overlookers, before they can communicate their instructions to them. I was told these girls were the descendants of Huguenot refugees, escaped probably from Provence to the Italian side of the Alps, at the revocatlon of the Edict of Nantes, and that they still retained their patois and their folk-lore; working hard, during the few months of cocoonreeling, from five in the morning until eight at night, for a franc a day; after work, dancing and singing for the hour before bedtime in the most joyous way. Apartments are provided for them at the factory; and, when the reeling season is over, they separate, and return to their Alpine villages, to wait for the next season's'work.
I took some of my wild cocoons, and, with much difficulty and patience, after several trials, succeeded in softening them, by the aid of long-continued boiling in water, to which were added soap, potash, and glycerine. When soft enough, one of the most skilled girls was told off to reel them for me, and, after ridding the cocoons of the outer and coarser threads, she reeled the threads of four cocoons into one, almost without a break, much to her own surprise, and to my delight.

The next day, the resulting tussur raw silk was taken to the throwing-mill, and there made into organzine and tram, of such fineness as to surprise the managers, who said they had no idea that tussur silk could be made of so fine a thread, and that they should think seriously about sending a person to India, to collect tussur cocoons, that their people might wind them after their mulberry crop had finished.

The usual size-that is, thickness - of thread of thrown tussur silk of commerce was, up to this time, $15^{2}$ to 255 deniers, that is, skeins of $\mathrm{I}, 000$ yards long, weighing 9 to 15 drams. From some of the finer raw-silk, a size of 6 to 7 drams was obtained, but it was generally coarser. From the cocoons the reeling of which I superintended, I obtained a size of $5 \mathrm{I}$ deniers, or three drams per I,000 yards, a much finer size.

Since that time, I have unwound an Indian tussur silk cocoon in an unbroken thread nearly three-quarters of a mile long, and of about three deniers. The reeling of it was effected by the ordinary French and Italian method, known as the system chambon. It is figured and described in my "Wild Silks of India ;" at that time the system Keller, which is now preferred in many filatures in Italy, had not been introduced.

\section{Chemical Nature of Silk.}

This paper would be incomplete without a few remarks on the chemical composition of tussur silk, and it will add more to the interest of the subject to compare the chemical natures of both the round fibre of the Bombyx mori, with the flat fibre of tussur silk.

An analysis of tussur silk was made under the direction of Dr. Knecht, by E. Bastow and J. R. Appleyard, students of the chemistry and dyeing department of the Bradford Technical College, in 1888 , which gave the followin per-centage results :- 


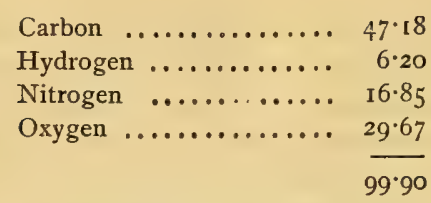

They do not state whether the analysis was made of the tussur silk of India, Anthercea mylitta, or that of China, the Anthercea pernyi; probably it was the latter, and as they differ in structure, and, no doubt, somewhat in composition, a determination of one or the other is still to be desired, and it would be interesting to see the analyses of both side by side, and also those of the gum or sericin of each species.

Let me now institute comparisons between ordinary silk and tussur silk. When the raw silk of commerce (Bombyx mori) is heated in water under pressure, it yields two compounds, fibroin and sericin, or silk gelatine.

Fibroin constitutes about 66 per cent. of rawsilk; it is a silky, glistening substance, which is insoluble in water, but dissolves in strong acids, alkalies, and a solution of cuprammonium sulphate. When boiled with dilute sulphuric acid, it yields glycocoll, leucine, and tyrosine.

There are two analyses of the fibroin of the silk of commerce (Bombyx mori), one by Mulder and the other by Schutzenberger, which are shown in the following table :-

\begin{tabular}{|c|c|c|}
\hline & Mulder. & Schutzenberger \\
\hline ......... & 15 & $\ldots \ldots .71$ \\
\hline Hydrogen ........ & 23 & $\ldots \ldots$ \\
\hline Nitrogen . & 5 & 24 \\
\hline Oxygen........ & 6 & $\ldots \ldots$ \\
\hline
\end{tabular}

Sericin or silk gelatin has a composition of $\mathrm{C}_{15} \mathrm{H}_{25} \mathrm{~N}_{5} \mathrm{O}_{8}$. It is a substance resembling gelatine.

Its hot aqueous solution is precipitated by alcohol, and after drying, the precipitate forms a colourless powder, which in cold water swells up to a gelatinous mass. On boiling it with dilute sulphuric acid, it yields a small quantity of leucine, and larger quantities of tyrosine and serine, or amidoglyceric acid.

Thus the silk of the Bombyx mori consists of two distinct compounds, the pure fibre, which is fibroin insoluble in water or soap, and sericin or silk-gelatin, which is the gum or gelatinous envelope or varnish of the fibre. It is partially soluble in water, and entirely dissolves and separates from the fibre in a boiling soap bath. Tussur silk has also this dual composition.

The following comparative Table shows that tussur silk is composed of the same elements as the silk of commerce, but in other proportions :-

\begin{tabular}{|c|c|c|c|}
\hline & \multirow[b]{2}{*}{$\begin{array}{l}\text { Tussur } \\
\text { silk. }\end{array}$} & \multicolumn{2}{|c|}{$\begin{array}{c}\text { The ordinary silk of commerce, } \\
\text { Bomby'x mori. }\end{array}$} \\
\hline & & $\begin{array}{l}\text { Calculated } \\
\text { for Mulder's } \\
\text { formula } \\
\mathrm{C}_{35} \mathrm{H}_{23} \mathrm{~N}_{5} \mathrm{O}_{6}\end{array}$ & $\begin{array}{c}\text { Calculated for } \\
\text { Schutzenberger's } \\
\text { formula } \\
\mathrm{C}_{71} \mathrm{H}_{10} \mathrm{~N}_{7} \mathrm{~N}_{24} \mathrm{O}_{26}\end{array}$ \\
\hline Carbon .... & $\begin{array}{l}\text { per cent. } \\
47 \cdot 18\end{array}$ & $\begin{array}{l}\text { per cent. } \\
47^{\circ} 78\end{array}$ & $\begin{array}{l}\text { per cent. } \\
5^{\circ} 26\end{array}$ \\
\hline Hydrogen & 6.30 & 6.23 & $6 \cdot 31$ \\
\hline Nitrogen & 16.85 & 18.90 & 19.84 \\
\hline Oxygen ... & $29^{\circ} 67$ & $26^{\circ} 04$ & $23 \cdot 60$ \\
\hline
\end{tabular}

The difference, therefore, between the composition of ordinary silk and tussur silk is as follows :- -Tussur silk contains less carbon, according toSchutzenberger's per-centage, which is $50^{\cdot 26}$; Mulder's per-centage giving $47^{\prime} 78$. Hydrogen is about the same in both silks; 2 to 3 per cent. less nitrogen, and about 4 to 6 per cent. more oxygen. I do not consider this difference of composition sufficient to account for the difference in the dye-absorbing qualities of the two silks, which I think depends much more upon their different physical structure, and the chemical nature of its brown colouring matter, not yet ascertained.

Besides this, there is the difference in the amount and nature of the gummy and gelatinous envelope secreted by the respective caterpillars around the fibre at the time of seriposition. In the Bombyx mori silk, the gum, or-as the French call it-grès, which encases the fibre as a varnish to preserve and protect it, amounts to 25 per cent. and upwards, in the case of China silk, and varies in other silks from 22 per cent. to 30 per cent. ; Bengal silk containing the largest amount. The foregoing analyses of its tussur-fibroin shows its nature. The composition of its gum or sericin has not yet been ascertained. From long experience of it I am convinced that it differs in constitution from that of the Bombyx mori, and there is a difference also in the sericin of the two tussur silks.

It is much more soluble in hot water than Bombyx mori sericin, but it was best removed from the fibre by a boiling soap-bath.

Chinese tussur silk contains more sericin than Indian tussur, and it is generally loaded with saline and dirty extraneous matter. Indian tussur is always cleaner, and contains a higher per-centage of silk.

The following Table shows the reduction of weight of I lb. each on China and Indian tussur silks as compared with the same quantities respectively of four kinds of the 
ordinary silks of commerce, Italian, China, Japan, and Bengal.

This is from a recent careful examination made by one of my sons for this paper.

\begin{tabular}{|c|c|c|c|c|}
\hline $\begin{array}{l}\text { Species of } \\
\text { Silk. }\end{array}$ & $\begin{array}{c}\text { Weight of } 1 \mathrm{lb} \text {. } \\
\text { after washing } \\
\text { in water at } \\
\mathrm{x} 25^{\circ} \mathrm{F} \text {. }\end{array}$ & 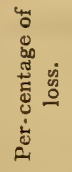 & $\begin{array}{l}\text { Weight of } \mathrm{I} \text { lb. } \\
\text { after boiling } \\
\text { in a bath } \\
\text { of soap. }\end{array}$ & 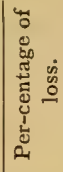 \\
\hline China tussur ... & 15 ozs. II drs. & $133^{\circ}$ & I2 ozs. II drs. & 21 \\
\hline Indian tussur. & 14 ozs. $9 \frac{1}{2}$ drs. & 9 & 14 ozs. 5 drs. & II \\
\hline China... & 15 ozs. $9 \frac{1}{2}$ drs. & $2 \frac{1}{2}$ & II ozs. 6 drs. & 27 \\
\hline Japan.. & 44 ozs. $11 \frac{1}{2}$ drs. & 8 & II ozs. 2 drs. & 30 \\
\hline Italian & 15 ozs. $5{ }^{3} \mathrm{drs}$ & 4 & II ozs. 8 drs. & 28 \\
\hline Bengal . & 14 ozs. $14 \frac{3}{4} \mathrm{drs}$. & $6 \frac{3}{4}$ & II ozs. 3 drs. & 30 \\
\hline
\end{tabular}

The soap, \&c., in the manufactured thread must be considered, as the loss is not all natural.

Peroxide of hydrogen reduces a large portion of the brown colouring matter of tussur silk, but causes a further loss of ro per cent. The gelatinous varnish of tussur silk is undoubtedly much more soluble in water than that of ordinary silk, and a few applications of boiling water will remove it altogether. I hope shortly to exa nine the chemical nature of the sericin of both the tussur species.

Bastow and Appleyard found a total loss of 26.49 in boiling tussur silk with water; and afterwards with soap solution. This rather points to the silk they examined being a sample of Chinese tussur, and loaded with its usual extraneous matters. I frequently find a still higher percentage of loss in Chinese tussur, occasionally as high as 45 per cent. The specific gravity they state to be I'440. They found a high percentage of ash in raw tussur, consisting of inorganic substances, in the following proportions :-

\begin{tabular}{|c|c|}
\hline & Per cent. \\
\hline Soda $\left(\mathrm{Na}_{2} \mathrm{O}\right)$ & I2.45 \\
\hline Potash $\left(\mathrm{K}_{2} \mathrm{O}\right) \quad \ldots \ldots \ldots \ldots \ldots \ldots$ & $3 \mathrm{I} \cdot 68$ \\
\hline Aluminia $\left(\mathrm{AI}_{2} \mathrm{O}_{3}\right) \ldots \ldots \ldots \ldots \ldots$ & I.46 \\
\hline Lime $(\mathrm{Ca} O) \ldots \ldots \ldots \ldots \ldots \ldots$ & $13 \cdot 32$ \\
\hline Magnesia (Mg O) .............. & $2 \cdot 56$ \\
\hline Phosphoric acid $\left(\mathrm{P}_{2} \mathrm{O}_{5}\right) \quad \ldots \ldots$ & $6 \cdot 90$ \\
\hline Carbonic acid $\left(\mathrm{C} \mathrm{O}_{2}\right) \ldots \ldots \ldots \ldots$ & II I I 4 \\
\hline Silicia $\left(\mathrm{Si} \mathrm{O}_{2}\right) \ldots \ldots \ldots \ldots \ldots \ldots$ & $9 \cdot 79$ \\
\hline Hydrochloric acid (C I) $\ldots . . . .$. . & $2 \cdot 89$ \\
\hline Sulphuric acid $\left(\mathrm{S} \mathrm{O}_{3}\right) \quad \ldots \ldots \ldots$. & $8 \cdot 16$ \\
\hline yggen equivalent to $\mathrm{C} I \ldots \ldots$. & $\begin{array}{r}100.35 \\
0.65\end{array}$ \\
\hline Total...... & \\
\hline
\end{tabular}

\section{SPELLING OF TUSSUR.}

In India, tussur silk has various names indicative of varieties, such as Tasar, TasarMuga, Data, Laria, Bogai, \&c., the four latter being applied to varieties of cocoons. In Europe it is known as Tussore, Tussah, Tusser, Tussur. Its general name in India being Tasar, the " $a$ " being pronounced as " $u$," it is therefore perhaps more correctly anglicised as tussur, which gives its exact pronunciation. This name is said to be derived from Tasara, a weaver's shuttle.

\section{Dyeing of Tussur Silk.}

The difficulties which have presented themselves from time immemorial in dyeing this silk, both in this country, the Continent, and especially in India, would occupy too long a time to relate. Forty-five years ago, my father, then one of the best English dyers, occupied himself in trying to overcome them, but with only very partial success. At that time the subject began to interest me, and I for some years gave special attention to it, but it was before it had occurred to me to study the physical properties and structure of its fibre, and almost before the microscopic powers of good definition and amplitude had been discovered, but I worked on in a tinctorial way with varying success, generally making some progress. Gradually I brought a fuller knowledge of chemistry to bear, which aided me greatly in the better application of tinctorial matter by chemical agencies. At first greys of various kinds were mastered, then a series of brown shades, and after some years of perseverance, reds, blues, greens, but not of very brilliant tones, succeeded, leaving for after years the solution of problems for producing good yellows, pale shades of blues, reds, and tertiary hues. It is singular that black and white were, and yet are, the most difficult colours to dye ; I say colours from a dyer's point of view, because both black and white are colours in that sense, and require the application of tinctorial matter, blue, yellow, and red, but in greatly diversified proportions, to produce them.

My results up to 1870 were exhibited at the International Exhibition at South Kensington, in that year, and appear to have attracted the attention of the India-office.

The reason that the dyeing of black is difficult arises from two causes; the first, the wellnigh impervious nature of the fibrillæ, and their consequent impenetrability to the absorption of ordinary tinctorial and chemical 
agencies; secondly, the flatness of the fibre, which causes the light to be reflected at different angles to that of the round fibre of the silk of commerce. This difference of structure causes the natural brilliance of tussur silk to be seen in scintillations instead of being evenly diffused over its surface, and the silk, however well dyed in black, has a speckled, shiny appearance, as you see it in this hank and in the drawing, but this convoluted or partially spiral narrow tape of shining tin-tape, and this cylindrical rod of the same material, will better illustrate my meaning and more clearly show the difference.

FIGS. I7 AND I8.

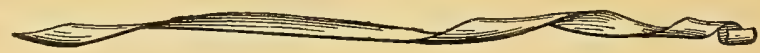

That tussur silk should be more difficult to Aye than mulberry silk may well be inferred, rom the difference in degree of solubility of the wo silks. A neutral solution of chloride of zinc, gently heated, dissolves mulberry silk instantly, whilst it only dissolves tussur silk slowly. In a cold solution, I found it took three days to dissolve mulberry silk, but, with tussur silk, a furtnight's immersion produced no effect.

The natural lustre or brilliancy of tussur silk is quite as great as that of ordinary silk, if not greater; but, owing to its peculiar structure, the effect of an equal diffusion of reflection is not possible.

These peculiar scintillations are not so easily seen in coloured tussur silk as in black. In pale colours, it is hardly distinguishable : the darker the shade, the more observable are its peculiar scintillations, because, at the points of reflection-that is, where they are at an angle of incidence with the eye, from the source of the light--a white point or surface appears, which, in contrast with blackness or a depth of colour, becomes a more noticeable feature. Manufacturers have yet to learn that the peculiar effect caused by this structural difference is really part and parcel of the natural property of the silk, and it ought to be considered, and even welcomed, as such. There is this charm in it, that monotony of structural regularity is broken up and varied.

As soon as I had overcome the difficulties of dyeing this silk in the ordinary colours of that period-for it was before the general adoption or introduction of aniline dyes-I had the honour to receive a communication from the India-office, in which it was stated that the Marquis of Salisbury-then Secretary of State for India-would be glad to know if I would consent to teach the natives of India how to dye this silk, which was both largely used there, as well as largely exported, in a native. woven cloth, called tussore or tussah, in pieces of to yards long.

These cloths were worn by the native women in India in the undyed state, and by English and French women, chiefly for sea-side dresses, also in an undyed state. I have such an example here. I saw many of them being woven in cottage looms in and around Berhampur, in Bengal.

Difficult as it was then to dye tussur silk in the skein, it was tenfold more difficult to dye it in the piece. Here is the best specimen I could find in India of native piece-dyeing.

I replied to Lord Salisbury's request by placing my services at his Lordship's disposal, stating that, as India was so rich in vegetable tinctorial products, I should advise the natives being taught to use them in preference to European dyes, especially as the very feeble and garish aniline dyes were rapidly displacing the oldfashioned and more stable ones. Instructions were at once issued to India for all the known dyestuffs to be collected, and in course of time such a collection was sent to me to examine and report upon, as to more than tax the space at my disposal to store them. It was a most valuable collection, and it took me, with an assistant, more than seven years to examine them. The result of that examination is before you in this Blue-book of eighty-two pages, entitled, "The Dyes and Tans of India," and in these 30 sheets of samples of woven silk, wool, cotton, and tussur silk. The whole collection consists of 360 sheets, containing about 3,500 dyed samples, illustrating the tinctorial results of $18 \mathrm{I}$ kinds of Indian dye-stuffs, which show the tinctorial properties of all the dyes commonly used in India. Since that time, a number of others have been reported, and it would be well if they were sent over for examination, so as to make the whole book complete. 
In parenthesis, I feel bound to mention that a work of this laborious and valuable nature has, as far as my experience goes, never had such scant treatment at the hands of the Government of any country. My book, as far any usefulness it possesses either to India or to Europe, is a dead letter, and it had been more economical never to have published it. It, so far, has been love's labour lost.

The method of publishing it was of the most parsimonious kind, entirely counteracting its usefulness. In vain I urged that it ought to be published in England, and to have the methods by which I succeeded in obtaining the beautiful colours you see here inserted in the book, and, what is quite as necessary, to have had pasted in the book small patterns of these coloured results, either the dried samples themselves or by chromo-lithography, obtained as they were by a more scientific application of mordants than those known to, or practised by, natives of India, who, when I went to India, at the request of the Government, in I885, and showed my results in dyeing and printing to the native dyers and printers with their own dyes, they were immensely surprised, and doubts were expressed as to the possibility of obtaining such excellent results with their plant dyes, but when I told them of the impure states of their sagimatti, alum and proto-sulphate of iron, almost their only mordants, as compared with the purer European salts, and also with a much larger range of metallic salts, which could be used with much better effect as occasion and colour required, they were convinced that, good as their dyeing, and especially printing, was, it was capable of great improvements. At Saharanpur, as Dr. Duthie, the curator of the Botanic Gardens there, will remember, if he should be present to hear me, I went the round of the dyers' and printers' with him, and each set of men, three or four in each dye-shop, in succession followed the rest, and, after I had seen everything I desired they sat down, at least, 50 or 60 of them, in a circle, with Dr. Duthie and myself in the centre, to examine the specimens I had brought with me. The spokesman, an old grey-haired Hindoo with dyed turban and white waistbelt, rose and said in Hindoo, "We have told Sahib all he asked us about our methods, will he answer any questions we. would like to ask him ?" I replied I should be delighted to do so, and for half an hour I was subjected to a cross fire of interrogations, such as only experts in the tinctorial art could ask, and which I freely answered. After passing my patterns round for some time, the old Hindoo rose and asked Dr. Duthie to state, that if Sahib would come to Saharunpur and establish a dye and print works on the English system, that both masters and men would willingly come and work for him. That was certainly a very encouraging, flattering, and striking episode in my interesting study of Indian dyeing and printing in India. Since that time, for all art work, I have chiefly used Indian dyes, from which I succeed in obtaining results in tone and permanence absolutely impossible with most of the artificial dyes, good as some of them are, and if the Government had followed up my arduous work for them in a prompt and thorough way, I am sure Europe would now have been doing a large business in dyes with India for all their bon teint purposes, and the Indian dyers themselves would have been able to make themselves acquainted with superior methods at present unknown to them. The way in which indigo, for example, stil! asserts itself is a sufficient proof.

But it is not too late. As taste improves, the weaker dyes are more disliked, and I would from this place urge the Government of India to make the work, so successfully begun by Lord Salisbury, complete. The Hindoo and Mahomedan dyers still remain untaught in the application of chemical science to their art, and the European dyers remain unaware of the excellencies of scores of, to them, unknown Indian dyes.

\section{Bengal SERICUlture.}

I will now turn to other interesting episodes of my Indian investigations. On arriving at Bombay, I received a message from Sir E. C. Buck, Secretary of Revenue and Agriculture, to proceed at once to Calcutta, where I received his instructions to visit the Bengal sericultural districts, where the Bengal silk of commerce is produced, the silk of the Bombyx fortunatus and Bombyx crosi, and to report upon the causes of their depressed condition and diminished output. I first went to the districts of Rajshaye, in which Surdah is situated, and then on to Berhampur.

I took with me this Italian tavelette (Fig. 19), which I found in Italy to be producing the best reeled silk, and explained its use practically in several filatures. Fig. 19 (p. 14) is a drawing of it.

I returned to Calcutta, and read a report, since published by the Department of Revenue and Agriculture, before an important meeting 
of gentlemen interested in the subject, and presided over by Sir E. C. Buck.

I found in some filatures very defective reeling, in all possibilities of improvement, but in the native-reeling villages the reeling

A.-An iron stand 12 inches high.

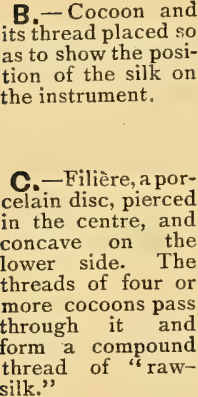

D.-Croissure or crossing of the raw silk thread six or more times round itself. The object of $t h$ is is to straighten and restraighten and ro move kinks, loops, in the thread.

E E.-Pulleys, the drums of which are formed of thin glass rods.

F F. - Porcelain eyelets or guiders attached to a brass frame which also supports the pulleys.

FIG. I9.

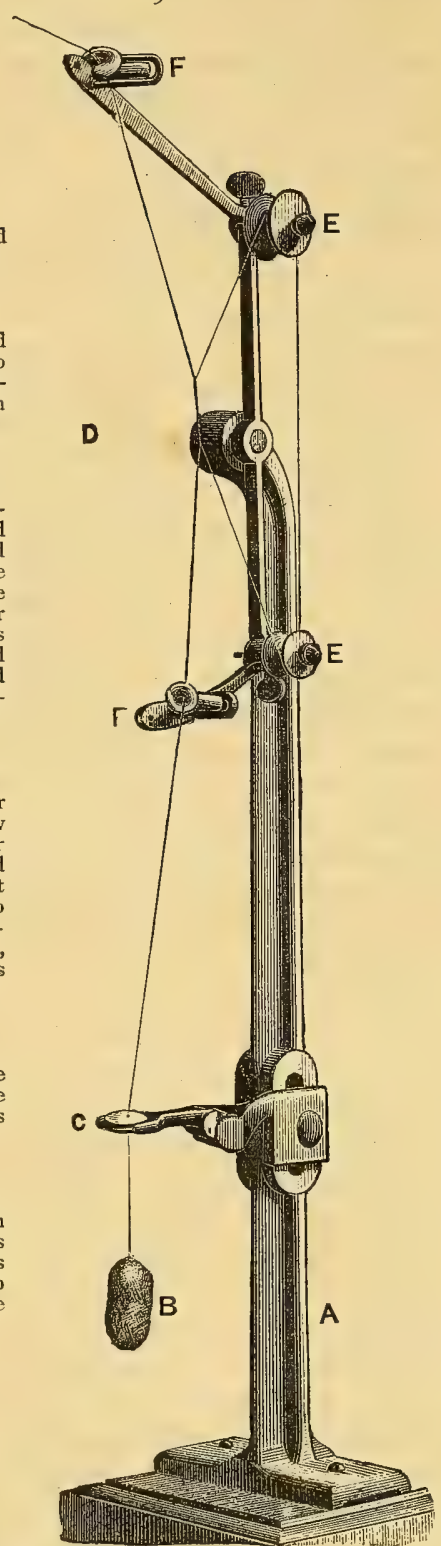

Italian System of Reeling Cocoons.

Tavelette Keller; sometimes, but erroneously, attributed to Consono.

was wretchedly bad. In the cocoon-rearing villages I found much preventible disease. Generally about 60 per cent. of the worms died from pebrine and other diseases. Let me draw a comparison between this rude and imperfect native system of reeling tussur cocoons and the European one. It will be easy to point out the superiority of the Italian method in two ways-first, the operation termed the croisette in France, is better done with the tavelette than by rubbing with the palm of the hand; the croisure effected by the hand is no croisure at allmerely a rolling of the individual fibres together. The operation of croisette effects the laying together into one compact thread the threads of two or more cocoons (usually from four to six), and in drawing off the pairs of individual cocoon threads or baves in a continuous and stretched-out manner so as to prevent, as far as possible, what the French call duvet, or thread irregularities.

The silkworm, by moving its head from one side to the other, deposits its double thread in loops, as at $a$, see Fig. 20 (p. I5).

At the points of contact, the gum adheres more firmly than it does laterally, consequently, in the reeling, the bave-that is, the double parallel fibres - frequently come off in loops, as at $b$, Fig. 20.

In Fig. 2I (p. I5) is given the appearance of duvet upon a thread of raw silk composed of four cocoons reeled together.

Fig. 2I (p. I5) is the microscopical appearance of an aggravated form of duvet, in which a series of layerlet of loops have come off together, and which, having passed both filière and croisure without being reduced, have resolved themselves into a tangle which constitutes what is known as "knibbiness" in the raw silk.

In native reeling it is much worse, and much more frequent. In the Bengal cocoon this defect is much aggravated from two causes-first, by the greater amount of gum or grès which the worm exudes to cover its silken thread than in those of the Italian, French, Chinese, and Japanese worms; second, from the Bengal cocoon being smaller and softer than those countries just mentioned. smallness increases the difficulty of reeling, especially towards the inner end of the cocoon.

In the Italian cocoons the chrysalis is larger than the Bengal ones, and helps by its greater weight to prevent the cocoon from being drawn out of the water in which it floats whilst being reeled.

Often for want of care whole layers come off at once, and form what are called "knibs," "foul," "slubs." This is particularly noticeable in village native reeling where irregu- 
larities of thread predominate, portions of the cocoons being drawn off in positive lumps.

The croisure materially helps to pull out the loops by running the threads round the pulleys at a considerable tension, and then by crossing them several times round each other as shown at $a$, Fig. 20. The threads plane against each other and the duvet is reduced. Duvet occurs in the best reeled Italian and French raw silks, but to such an extremely limited ex- tent in the higher or better reeled qualities as to be almost invisible.

I did not meet with any one in Italy, when studying this defect, who could explain its true nature or cause, and I pointed out under the microscope that it was simply unresolved loops, which in all good reeling must be pulled out to form a straight even thread. This, the Italians think, is best done by the Tavelette Keller. (See Fig. I 9, p. I4.)

FIG. 20.

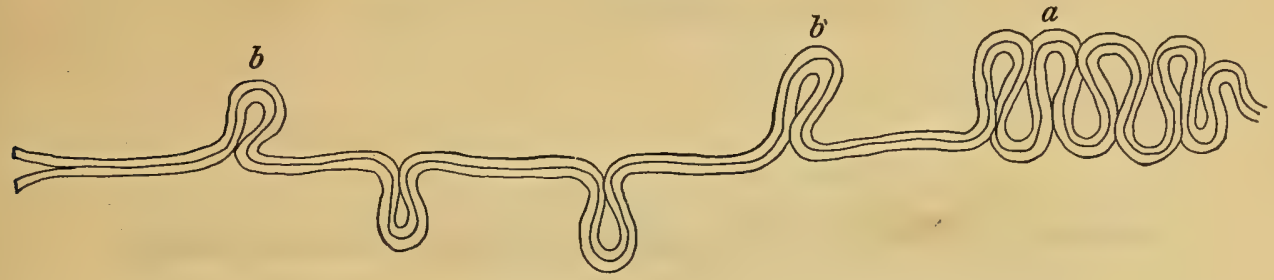

FIG. 2I.

FIG. 22.

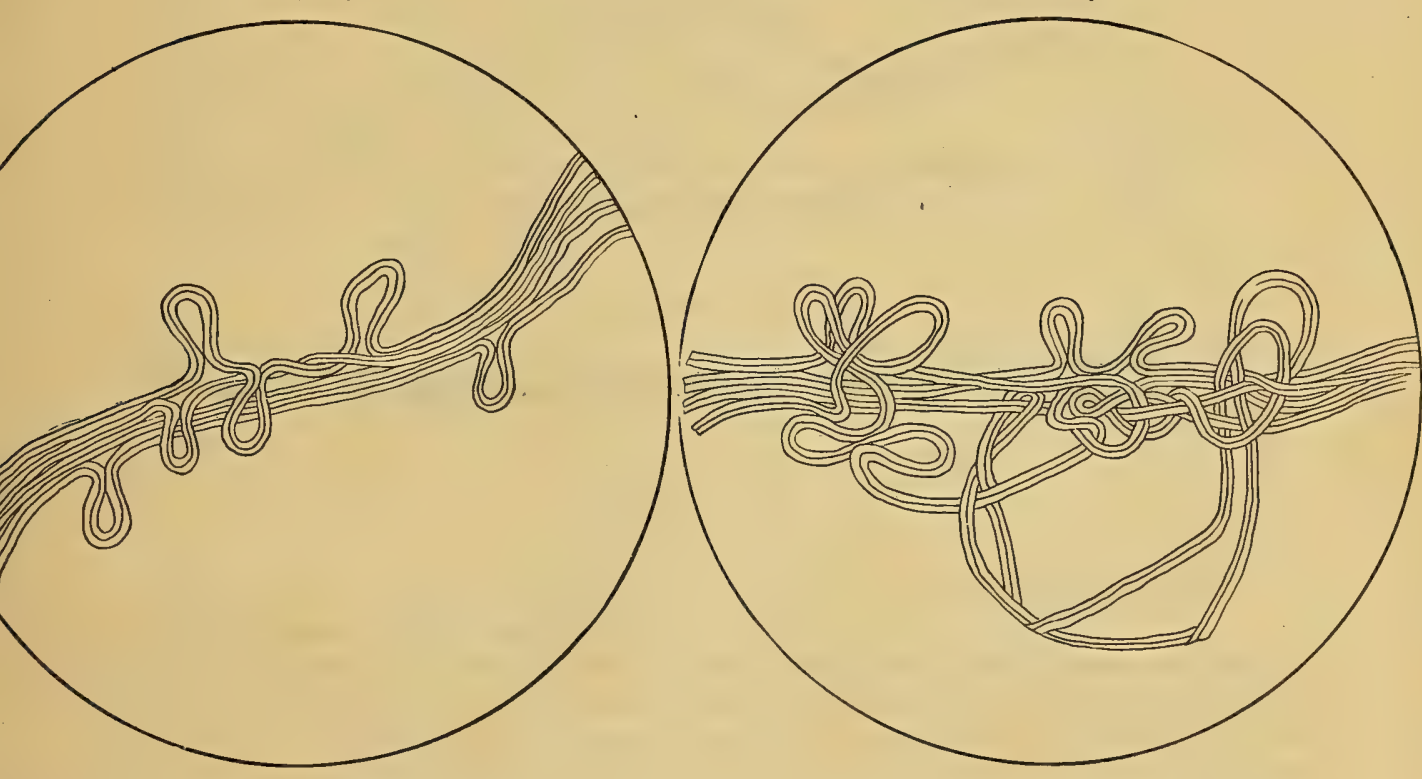

Our Indian sisters could thus substitute a more cleanly and less toilsome method for their own, which to us seems burdensome and indelicate, requiring them to sit the live long day upon the clay floor much exposed. Several of the old women reelers at Futwah were much bent and very rheumatic by their many years of toil in a constrained position upon a cold floor.

The Figures 23,24 , and 25 (p. I6), show a microscopic representation of defect and cure of duvet. They accompany a pamphlet issued by the Chantier de la Buire Compagnie, machinists of Lyons, descriptive of a new automatic cocoon-reeling machine, which they allege obviates skilled labour.

There were also other difficulties fully mentioned in my report, all of which could be easily ameliorated by an Imperial bacteriologi cal and educational effort, similar to that in France and Italy, and which I strenuously urged. A station has since been established at Berhampur, and is directed by $\mathrm{Mr}$. Nityal Gopal Mukharji, who was first sen to the Government Sericicultural establishment of Montpelier and Padua, after having 
studied the treatment of the various silkworm diseases at Paris under M. Pasteur.

Much improvement in reeling has been recently effected, and Bengal silk finds more favour in Europe on that account, and it has now a value of upwards of $3 \mathrm{~s}$. per $1 \mathrm{~b}$. over the price obtained for it at the time of my visit.

FIG. 23.

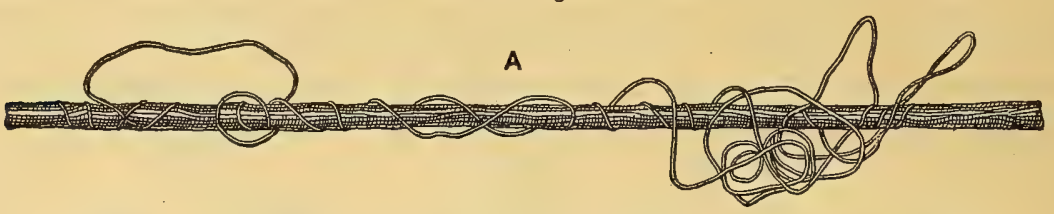

Reeled by a good French Reeler by Hand, System Chambon.

FIG. 24.

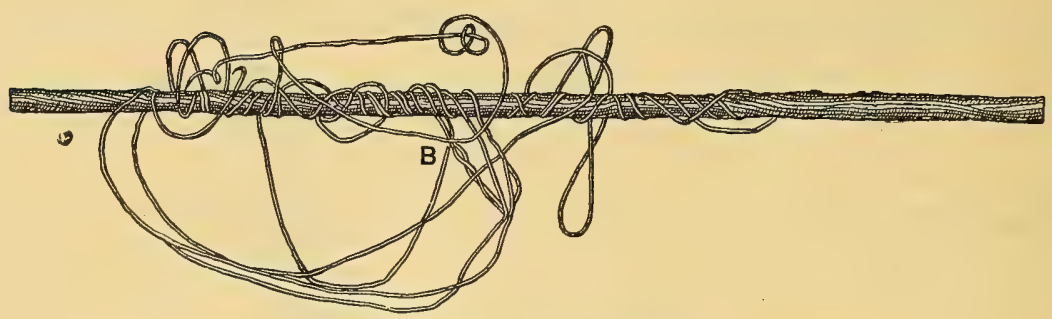

Reeled by an Apprentice by Hand, System Chambon.

(Magnified 5o diameters. A \& B, duvet.

FIG. 25.

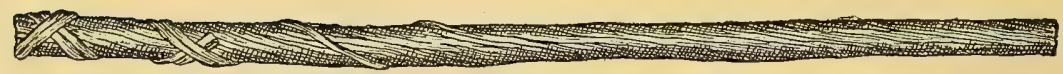

Reeled Mechanically, New System. (Camel.)

(Magnified 70 diameters.)

\section{Manbhum Tussur-culture.-} The Santals.

I was then despatched by the same authority to Manbhum, in central Bengal, to report on the capability of the Santal people and district to increase their output of tussur silk, which was at that time in vastly increased demand.

I stopped at a jungle station called Jamtara. Here the Rev. A. Campbell, a missionary, met me with twelve of his Santal people. We journeyed five hours into the interior, to his bungalow at Pokhuria, in Govindpur, a subdivision of Manbhum district, not far from which is the celebrated and sacred mountain, Pareshneth, 4,460 feet high.

I found myself now far away from all Hindoo and Mahommedan civilisation, amongst a tribe of demon-worshipping Santals, who live in alternating villages with the Kohls, both peoples being tribal aborigines.

The day after my arrival, I was led into the jungle by $\mathrm{Mr}$. Campbell, who had previously shown me, for the first time, two beautiful fullgrown tussur silkworms, feeding on a tree in his garden. The tree was a young Terminalia tomentosa, one of a number which he had some time before planted, in order that he might study the cultivation of the tussur-worm for silk-producing purposes, and to instruct the natives.

They are both preserved in spirit, in this bottle ; but they have lost somewhat of their size, and also their beautiful colour. But both colour and size are well-illustrated in the enlarged drawing on the screen, and in that showing its natural size. I had never before seen such a beautiful living object and I felt 
FIG. 26.

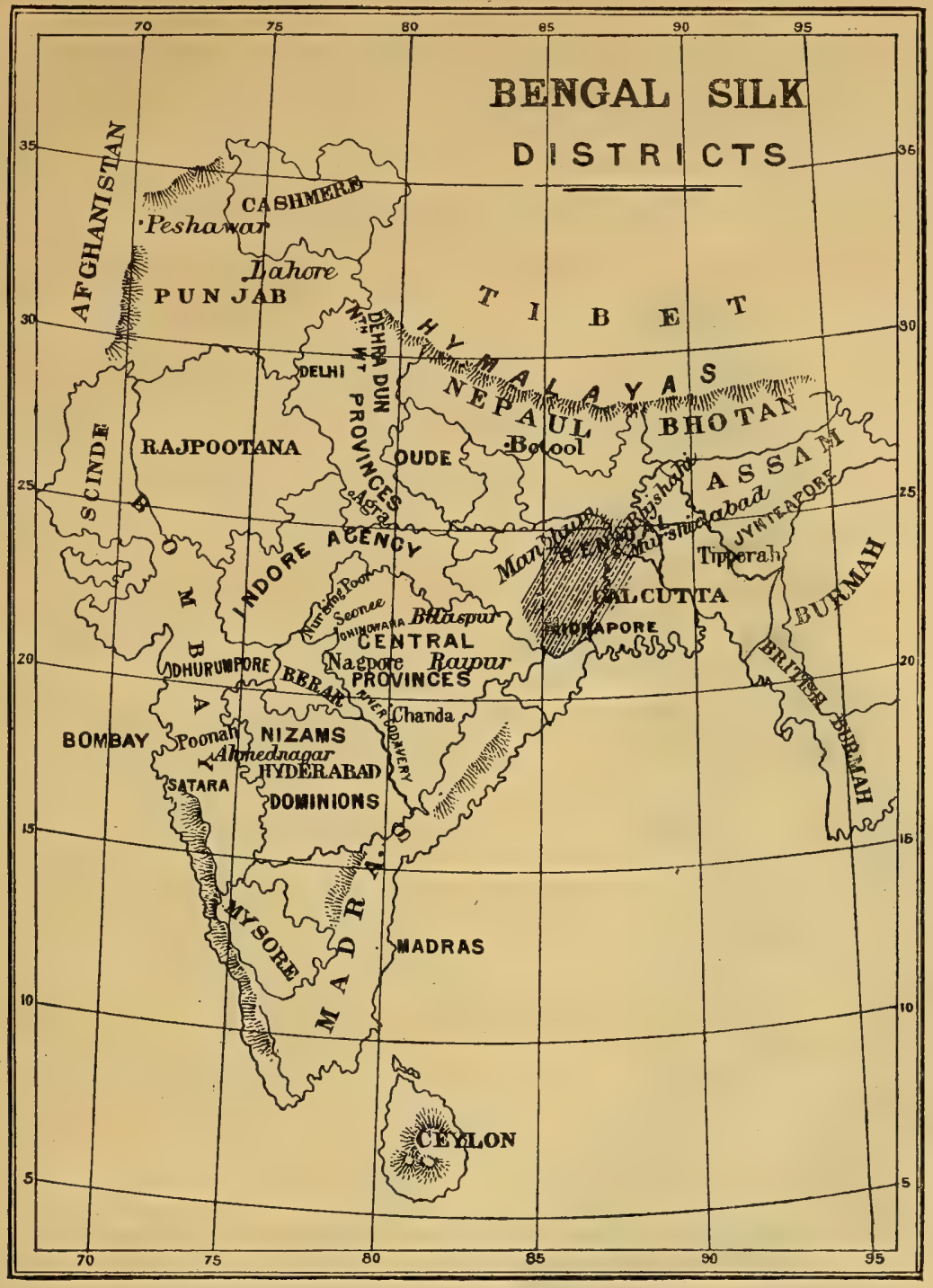

The Shaded Part shows the Bengal Silk Districts.

quite repaid for all the attention I had given to tussur silk (Fig. 27, p. 18).

Deep in the jungle, I was brought to the last season's tussur breeding-station, and, in an acre of forest, a most desolating appearance I beheld.

Most of the trees were Terminalia, of two species, and Shorea robusta. They presented that bare and shaggy appearance which can be imagined when all the leaves are stripped off, and all the smaller branches lopped.

The leaves had been devoured by the tussur caterpillars. After this feeding-stage of their existence, they began their cocoon construc- tion, by first attaching to the twigs the pedicles on which they formed their cocoons. When the gathering time came, the Santals, instead of cutting the pedicle, and allowing the cocoon to drop, cut off the twig, cocoon and all, with hooked knives and long sticks. This caused the trees to die; and Mr. Campbell said he had failed to dissuade them from this absurd practice, because of their love and determination to claim uninterfered with forest rights. $\mathrm{He}$ asked me to address them on the subject, and the next day they invited me to join their hunt, and to see them armed with bow and arrow, and accompanied with four bamboo 
fifes and two tom-tom drum:. We came across several dead patches of trees, the wreck of pre$v$ ious years of tussur culture. In one of them I stopped, and made an earnest appeal to them -about 50 in number-not to kill the trees, but to lop off only the cocoons; and on my telling the fable of the goose and the golden egg, solemnly translated into their Santal

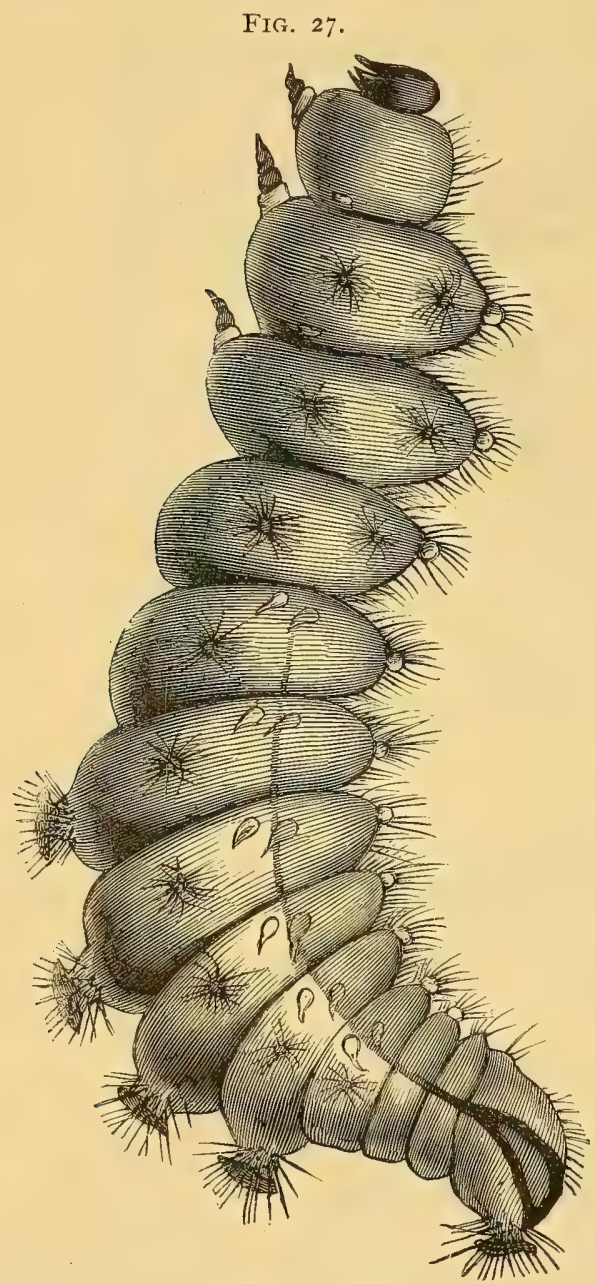

LARVA OF ANTHEREA Mylitta, or Tussur SILKWORM.

tongue by $\mathrm{Mr}$. Campbell, they were so impressed that they promised me that my wishes should $b$ ? complied with in future. But my object in mentioning this is to point out the immense area of jungle forest in which grow the trees whose leaves form the best food for the worms. As far as the eye could reach from any rising ground, and for hundreds of square miles, there lay a forest in which it seemed any quantity of the tussur of the future might be cultivated, and I think it is worthy of the attention of the Government of India to encourage in every way a greatly increased production, and not to be behind China in this respect, remembering that it has once happened, when I showed how tussur silk could be utilised, that such a demand sprang up as was chiefly met by the greater quickness of the Chinese.

Practically speaking, over the greater part of India, tussur silk might be cultivated, and there is vastly more area for such a purpose than there is there for growing cotton, as may be seen from the shaded parts of the map (Eig. 28 , p. 624), where, I have been informed, the tussur moth, in greater or less abundance, is to be found (Rajpootana is not shaded, because I had no reliable information about that part of India). I shall, by and by, add force to these remarks by showing you how enormously the consumption of tussur silk has increased in Europe since 1878 , the Paris Exhibition year, and consequently what an increased demand presents itself for India to supply. It has been a disappointment to me to see India, for whom only I was so anxiously working, so lethargic during such yearly increasing requirements, and allowing China to send in the lion's share of supply. As we often find in the English character, so I found in the Anglo-Indians, a greater readiness to find objections than means, and to this must be added the lethargy of the natives, and so India has missed an initial opportunity, which I hope the now greatly increased and secured state of European consumption will prompt her to secure for the future.

This is not the occasion to speak much of the Santals. I could easily fill a volume with an account of my most interesting and charming visit to these people, but I may be pardoned, if only to relieve the monotony of a dry address on silk, to give a brief outline of what I learned about them from Mr. Campbell and from my own observations, and of their beautiful country; and, besides, I have a purpose in doing so which is strictly related to the question of tussur culture.

The Santals are a people whose mountain home originally was in the Himalayas. They now inhabit the western frontier of Bengal, almost from the sea to the hills of Bhagulpore, on an extent of country of about 400 miles long by roo miles broad, or about 40,000 square miles.

In the more westerly parts of this large tract they are the only population, altogether 
FIG. 28.

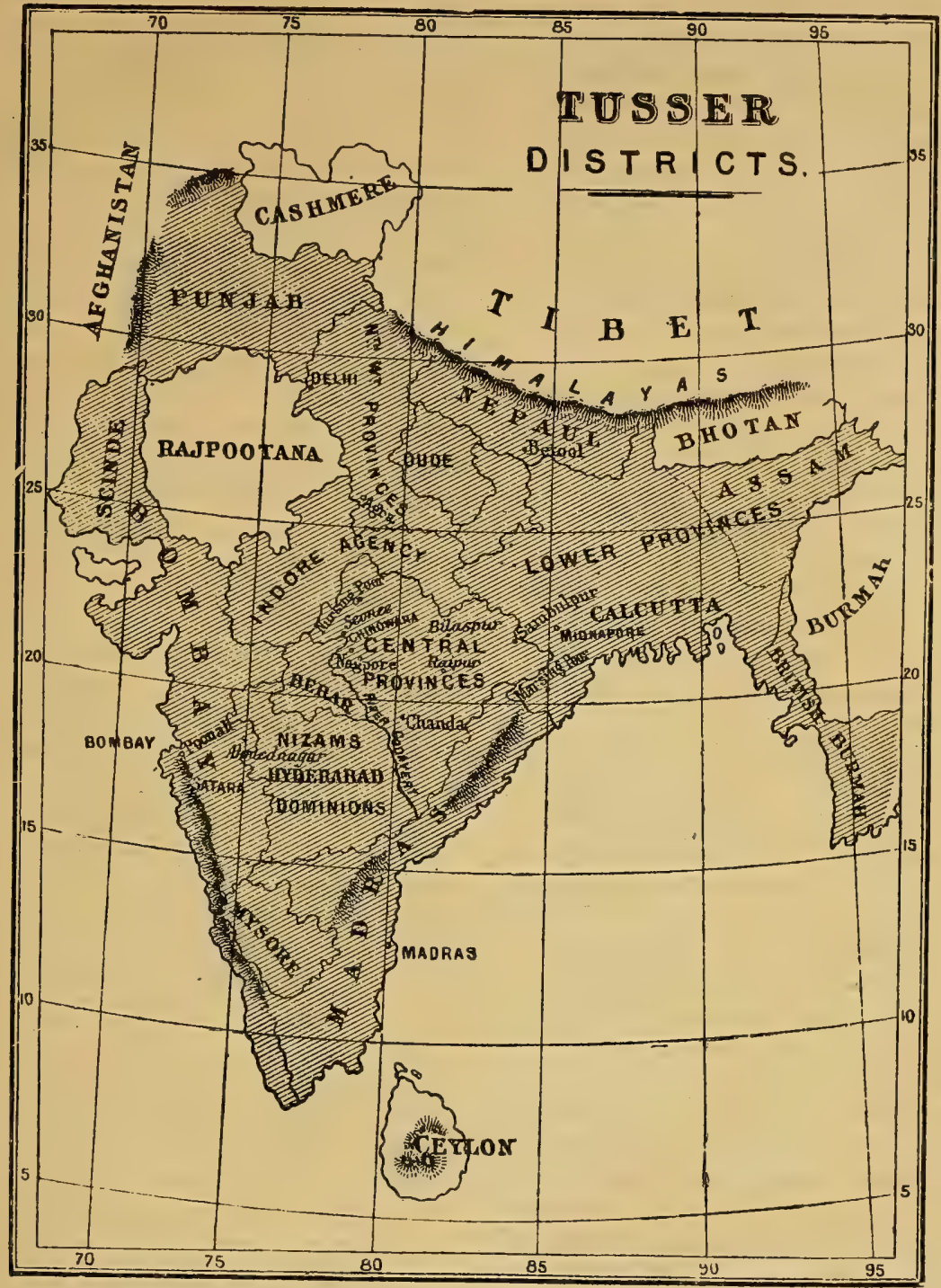

THE PART SHADED SHOWS WHERE TUSSUR SILK IS INDIGENOUS.

they are about $1,500,000$ in number. They are children of the forest, speaking one language, the Santal language. They have no written language, but my friend the Rev. G. Campbell, gave me little books in which their lan. guage has, by various missionaries, been condensed and printed, containing hymns which I had the pleasure of hearing sung, or rather chanted, to their native Gregorian-like strains, by the Pokhuria Santal maidens who assembled in Mr. Campbell's bungalow, that I might hear them.

As a resemblance in language I will just mention one word, "man," which, primarily, signifies a thinking animal, and has in Sanskrit "man," to understand; "manu," the the first man; and "manava," man in general; whilst the Santals have " man-ete," to think; "man-e" the soul; and "maniko," the first man; with "man-o-i," in general; and " man-jaman, born of man.

The Santal is very well proportioned, his height is about 5 feet 7 inches, weight about 8 stone, strong, very hardy, round-headed and round-faced, with a pleasant expression; the women especially clothed but very scantily, not too little, not too much, garments in such a hot country being an encumbrance. 
SANTAL Customs.

They have all the same customs; they are of one race of seven tribes, a division derived from their belief in the seven children who were the progeny of their first and common parent-ancestors. They have all the same religious customs, but it is religion minus a beneficent god. The Santal can only believe in a supreme being whose object is to harm him - a religion of terror, and a praying against evil, and not a praying for good. The effect of the missionary, when explaining the attributes of the Deity, is to make them fear still further, and to exclaim, "and what if he should eat us." They believe in evil spirits, and in many rites and ceremonies to propitiate them, each family having its own deity, and unknown to other families; the knowledge of the family god is transmitted from generation to generation by the death-bed communication of the father to the eldest son, and it is a representation of the secret spirit and principle of evil which has an unseen but ever present embodiment in each house.

Besides, their family religion includes the worship of the ghosts of their relatives and ancestors, which require pacification in order to prevent them being hurtful to the family, by inflicting sickness or other domestic and agricultural troubles.

I have seen their clay aitars, and their sacred groves where they go to rate and blame their ancestors, with violent gestures striking the altar on the loss of a cow or other trouble.

They have in every village a sacred grove, consisting of about a dozen large Sal or Shorea robusta trees (a favourite food of the tussur worm) and seven stones, some marked red. They believe the grove is the resort of their deified spirits and ancestral ghosts, and there they celebrate their rites and festivities in joyous dancing, or appeasing sacrifices to the demon and evil spirits whose malignance they are for ever fearing, and against which they are ever supplicating, and, as has been aptly summarized, they know no god who will reward the good, but a host of demons are ever at hand to punish the wicked, to scatter and to spread murrain among the cattle, to blight the crops, and only to be bribed by animal suffering, and by a frequent outpouring of blood in sacrificial rites.

I asked my missionary friend, if this religion was such a deeply-rooted one, and so opposed to our ideas, how he managed to make Christian converts. He said it was next to impossible to do so; but his influence with them, as I had daily opportunities of observing, was immense. It was more of a fatherly and friendly kind than that of a change of belief ; a possible grafting of the new upon the old, requiring, perhaps, ages for its consummation. In a dozen years of devoted missionary work he had made but few Christians, and those chiefly of his own entourage, yet he was all but worshipped, and I never saw such devotion to any one man. He told me he frequently camped out amongst the varions tribes in turns, and often preached to upwards of a thousand people, young and old, of both sexes, who flocked from far and near to hear the great father, who was their trusted friend, both against the rapacity of the Hindoo, whom they both feared and hated, and in their troubles and disputes of all kinds, as well as being their great " medicine."

The Santal youths marry at about sixteen, and the maidens at about fifteen ; and, as Dr. Hunter states, a leaf hut, with a few earthen and brazen pots, is all the establishment a Santal young lady expects. The houses in their villages were of clay or bamboo with a sloping roof, in contrast with the houses in the Kohl villages, whose housés had flat roofs.

The Santal maiden sometimes claims her right of choosing her lover. To do so, she takes a dish of prepared rice, and he is done for ; he must eat it, and is bound to marry her. The marriage takes place in the market before witnesses, when he dabs her forehead with red paint.

To me the Santals were very kind and considerate. They carried me on their bare shoulders across rivers; showed me how to use their bow and arrow, their only weapon. The young women sang to me; both young and old men showed their powers in aiming their arrows at a fixed mark; in other games; and in hunting in dense jungle, using arrows pointed with sharp spear-heads of native steel for large game, and a wooden button at the arrow end for birds, which they can hit flying. It was a highly-privileged and neverto be-forgotten experience. One of the oldest men, after giving me a proof of the accuracy of his aim, pressed upon me the acceptance of a lasting memento in the shape of his beloved bamboo bow and arrow, which I have brought as one of the illustrations to my paper. The bowstring is also bamboo (Fig. 29, p. 626).

But most wonderful of all is their account of the origin of the world and mankind, and in their traditional beliefs in these respects. They bear great resemblance to the Mosaic record 
in several particulars, analogous to the creation, the deluge, the first human pair, their first being clothed, propagation of children, the dispersion; the formation of the earth by its being raised up above the sea (which was of old universal) at the command of the Great Lord Marang Buru, who called a tortoise to lift up the earth, and when he had done so the Great Lord found it not to be solid enough, and commanded the tortoise to sow the seeds of grass to let the roots first take hold.

Their houcehold god is the Great Mountain, which represents a life-sustaining prov dence; to which they offer sacrifices of blood. Their priests worship the brother and sister who were the first man and the first woman of the Great Mountain, and sacrifice to them white goats and fowls on the banks of the Damooda, or with a red flower or red fruit, typifying thus a blood sacrifice.

Sir William Hunter relates a modified version of the tradition, which varies in different parts of the Santal country.*

The Great Mountain stood alone among the

FIG. 29.

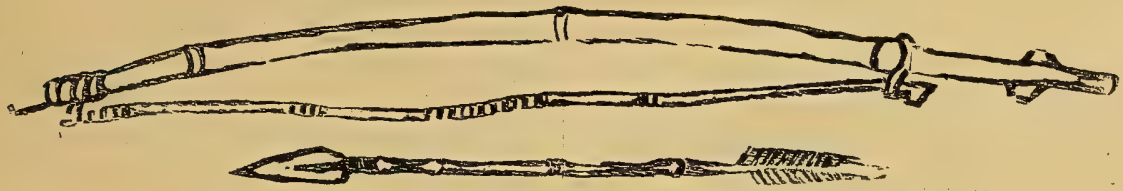

SANTAL Bow (UNBENT) ANU ARrow.

waters and talked to himself in solemn solitude. He saw that birds moved upon the face of the waters, and he put them on a water-lily in the midst of the waves and let them rest there. The huge prawns were created, and the prawns raised rocks from under the waters, and likewise the water-lily, the rocks afterwards became covered with all manner of creeping things, and the Great Mountain said, "Let the creeping things cover the earth " and they covered it. Then the Great Lord commanded the Great Mountain to sow grass, and when the grass grew up the first man and woman arose from two duck eggs that had been laid upon the water-lily. Then the Great Lord asked the Great Mountain, "What are these?" and the Great Mountain answered, "They are man and woman. Since they are born let them stay."

The Great Lord saw they were naked, and he commanded the Great Mountain to clothe them, and he clothed them. Then the Great Mountain said, "The land is, and the man is, and the woman is, but what if the man and woman should die out of the land. Let them have children, and they had seven."

The tradition of these people, from which their present seven tribes spring, rather mixes up the creation with the deluge, and, probably, begins with the deluge and subsidence of the waters, or, rather, as Sir William Hunter puts it, the Santal legend describes rather the subsidence of waters than a creation.

Their river Damouda, of which the Barak- har, which I crossed, being carried over its dangerous sifting sands on the bare shoulders of three Santals, is the main tributary. It is held in veneration by the Santals, who make an annual pilgrimage to its banks, to consult the prophets and diviners, and to commemorate their forefathers by a ceremony, which they call the purifying for the dead. Sir W. Hunter relates that, however remote the jungle in which a Santal may die, his nearest kinsman carries a little relic of the deceased to the river, and places it in the current, to be conveyed to the far off Eastern land from which his ancestors came.

Sir William Hunter relates that instances have been known of a son following up the traces of a wild beast, which had carried off his parent, and watching, without food or sleep, during several days for an opportunity to kill the animal, and secure one of his father's bones to carry to the river.

Mr. Campbell told me that immorality was almost unknown amongst them, and, when it did occur, expulsion and death in the jungle was the fate of the unhappy outcast. The Santals have one wife only. I could write pages of what I learned as to those interesting

* The "Annals of Rural Bengal," by W. W. Hunter, LL.D., a most interesting work, which not osly agrees with my Santal experience, but contains a more exhaustive account of this tribe than I had opportunities of observing, and to which I am here indebted. I had the pleasure of meeting Sir William (then Dr.) Hunter in Cal cutta. 
Phases of life, courtship, marriage, death, and burial (a beautiful ceremony), and the future world; but this is not the place, for, fascinatir $g$ as the subject is, I havealready digressed too much, but only to bring vividly before you the interesting country in which the Santal dwells -his lowland and mountain junks, produce of wild silks, beautiful dyes, gums, tans, drugs, bees'-wax, timber, and, as Sir W. Hunter states, a little world of barbaric wealth, to be had for the taking, and last, but not least, the home of the tussur silkworm, where, by due attention to tussur sericulture, may be produced silk in inconceivable quantity.

\section{SANTAl TUESUR-Culture.}

But to return to Santal tussur silk. The price at which the Santals sell their tussur cocoons is 5 to 7 rupees for 800 cocoons.

The Santal tussur silkworms, which produce the selling crop of cocoons, feed on the Terminatia tomentosa, and form their cocoons on its branches in October. They are gathered as soon as the cocoon hardens, which is in three or four days after the cocoon is completed.

The worms for the breeding crop are fed on the Shorea robusta; they make their cocoons on the same trees towards the end of the hot weather. The term of the chrysalis stage varies a good deal, some of the moths emerge in one, two, or three months, some at four, five, and even six months.

Mr. Campbell told me he had had some of the October brood which did not emerge until the following June. The moths fly high, and are only to be found on tall trees. The male moth always flies at night in search of a mate, from dark until about two the next morning, and is known to travel very long distances.

The female moth flies from tree to tree, depositing three or four eggs on the leaves each time she alights, and, whilst laying her eggs, her wings are always in motion.

For domesticating, the females are put into a basket, so that all the eggs are gathered, but in the wild state she lays her eggs always on leaves. They will keep for ten or twelve years.

In cultivating the tussur worm in a semidomesticated way, by the Santal, it is fed on gathered leaves. The eggs are taken into the jungle in little bags, and are attached to branches, and they are then watched incessantly night and day for a week. The Semecarpus anacardium is used on a stick to catch insect pests. To prevent the ants from climbing the trees, they either tie a leaf round the tree, or make a mark round the stem with the oil of Semicapens. No insects will pass over it. I saw many trees so ringed at the base.

The important cocoon harvests in Manbhum are in October and November, but there are as many as six broods a year. The principal food-trees are:-Terminalia chebula, Terminalia bellerica, Terminalia tomentosa, Terminalia arunja, Shorea robusta, Zizyphus jujuba, Lagerstroemea parviflora, Careya arborea, Diospyros tomentosa, Al. stonia scholaris.

Mr. Campbell said the best plan to promote increased tussur culture there would be for some capitalist to take the forests and employ ryots to collect the cocoons, conditionally that they did not lop the trees. He said the output of tussur silk would then be enormously developed.

I stayed nearly a week amongst them, hospitably entertained by the Rev. Mr. Campbell, whorn I found greatly revered by them. I found them a most interesting people, affectionate, of strict morality, and most obliging. The same twelve who brought me from the railway station into their wilds, took me to Jamtara; I on pony-back, and they, all but nude, carrying my luggage hung to each end of poles carried over their shoulders. I had lingered too long on my last day at Pokhuria, and it was late in the day when I left, so we had to traverse the roadless jungle for three hours in the night, with no other light than a lantern and the stars overhead, and occasional colonies of fireflies slowly sailing about, amid the roars and howls of tigers, leopards, panthers, and other feline animals, ${ }^{*}$ the unearthly cries of hyenas, the diabolical yells of packs of jackals, sometimes close to us, other packs distances away, yelling to each other, like villages of demons with wild dogs, and other animals commencing their nightly prowl, and never knowing which moment might not find one of us seized by a tiger; for this part of Bengal is the home of tigers, frequently hunted by large bands of Santals with bow and arrow. I rode with loaded rifle in hand, and it was a relief to all of us when we arrived at Jamtura station,

* There are nearly twenty species of the genus Felis in India, of which Felistigris, the Bengal tiger (Hindee, Bagh), Felis pardus, the panther (Hindee, Gorbach), Felis leopardus, the leopard, Felis jubata, the cheetah, are the principal ones, and are common; Hycena striata (Bengalee, Naukra bagh); jackal, Canis aureus (Hindee-Bengalee, Siar); wild dog, Canis rutilans. 
about ten o'clock at night, where I waited for the night mail, which took me to Bankipur for Gaya.

\section{GAYA.}

I arrived at Gaya the next day, on the 29 th of January, I886, at Io o'clock, where I met Dr. Macleod, to whom I had a Government letter of introduction.

This centre of religious places is held in veneration by Hindoos, both in the adjoining semimountainous country and in the plains abounding with historic rock-temple remains of the great Buddhist faith, now extinct, but which in almost prehistoric times prevailed there, culminating at Buddha Gaya, about six miles from Gaya. The town of Gaya has a population of $76,000,60,000$ of whom are Hindoos. Part of the town is occupied by the residences of the priests, and there is also the trading quarter.

I found a rather large tussur cocoon collecting centre at Gaya, collectors penetrating the vast jungles south of Gaya and far into the extensive division of Chota Nagpur, of which the towns of Hazaribagh and Ranchec, respectively about 60 and I20 miles distant from Gaya, are well-known centres of tussur cocoon production; the neighbourhood of Ranchee being also where I first obtained the interesting cluster cocoons of grape-like growth of the Cricula trifenestrata wotm, which excited so much attention at its first introduction into England in the Silk Culture Court of the Colonial and Indian Exhibition in 1886.

At Gaya I found tussur cloths of this description being woven, and consequently a good deal of cocoon reeling done in the same manner as at Fatwah and Arrah. Here are samples of two qualities of tussur reeled raw silk I brought from there. It is of superior quality, being fairly well reeled, and this is a Io yard piece of their weaving.

I bought two bundles of native reeled tussur raw silk for eight annas. The price of cocoons was Io annas per 1,000 , or Is. 3 d.

The tussur cloth weavers earn four to six annas per day, and have besides a bonus of two annas per piece.

The cocoon reelers at the adjoining villages of Gunyat Gaya and Mannpur use horeh, a decoction of the Myrobalan nut, the fruit of Terminalia chcbula, in reeling the cocoons; before reeling them, they boil the cocoons two or three hours in sagi-mati to soften them.

The reelers earn 3 rupees per month, they are provided with two meals a day, and some clothing every six months. They work seven days per week, thus earning 2 annas per day. There are 16 annas in a rupee, and reckoning the Indian value of a rupee at 25 , an anna is worth $I \frac{1}{2} \mathrm{~d}$.

After having visited the bazaars of Gaya, and seen their primitive basket and pottery making, I made the customary pilgrimage to Bodh Gaya, or, as Sir Edwin Arnold spells the the first word, Buddha. Gaya is also spelt Gya.

My visit to Buddha's shrine, and to the scene of his retirement at the Great Renunciation, was in obedience to an irresistible impulse caused by reading and re-reading Sir Edwin Arnold's "Light of Asia."

\footnotetext{
"Thou, who wouldst see where dawned the light at last, North-westwards from the 'Thrusand Gardens,' go By Gunga's valley till thy steps be set

On the green hills where those twin streamlets spring, Nilajân and Mohâna ; follow them,

Winding beneath broad-leaved mihua-trees,

'Mid thickets of the sansar and tho bir,

Till on the plain the shining sisters meet

In Phalgú's bed, flowing by rocky banks

To Gâya and the red Barabar hills."

"Near it the village of Senani reared

Its roofs of grass, nestled amidst the palms, Peaceful with simple folk and pastoral toils. There in the sylvan solitudes once more Lord Buddha lived, musing the woes of men, The ways of fate, the doctrines of the books, The lessons of the creatures of the brake, The secrets of the silence whence all come, The secrets of the gloom where to all go, The life that lies between."
}

\section{Light of Asia}

The great tower-temple, the pipal tree under which he sat, his five years of meditation, the ruins of a sublime past architecture, the pilgrimage of thousands annually to this shrine, I must not here describe.

Let it suffice me to say that this great land of the tussur silk teems with interest, and calls out for the encouragement of Imperial attention quite as loudly as do also the requirements of the smaller and more valuable silkworms now perishing with diseases in the old East India silk districts.

\section{ARRAH.}

My visit to Gaya being ended, I went to Arrah, and I will now say a few words about my visit to that place.

Arrah is a municipality in the Shahabad district, in Bengal, a few miles south of the Ganges, with a population of between 40,000 and $50,000-30,000$ of whom are Hindoos, and the rest Mahomedans, with about forty Christians.

\footnotetext{
- Now Buddha Gaja
} 


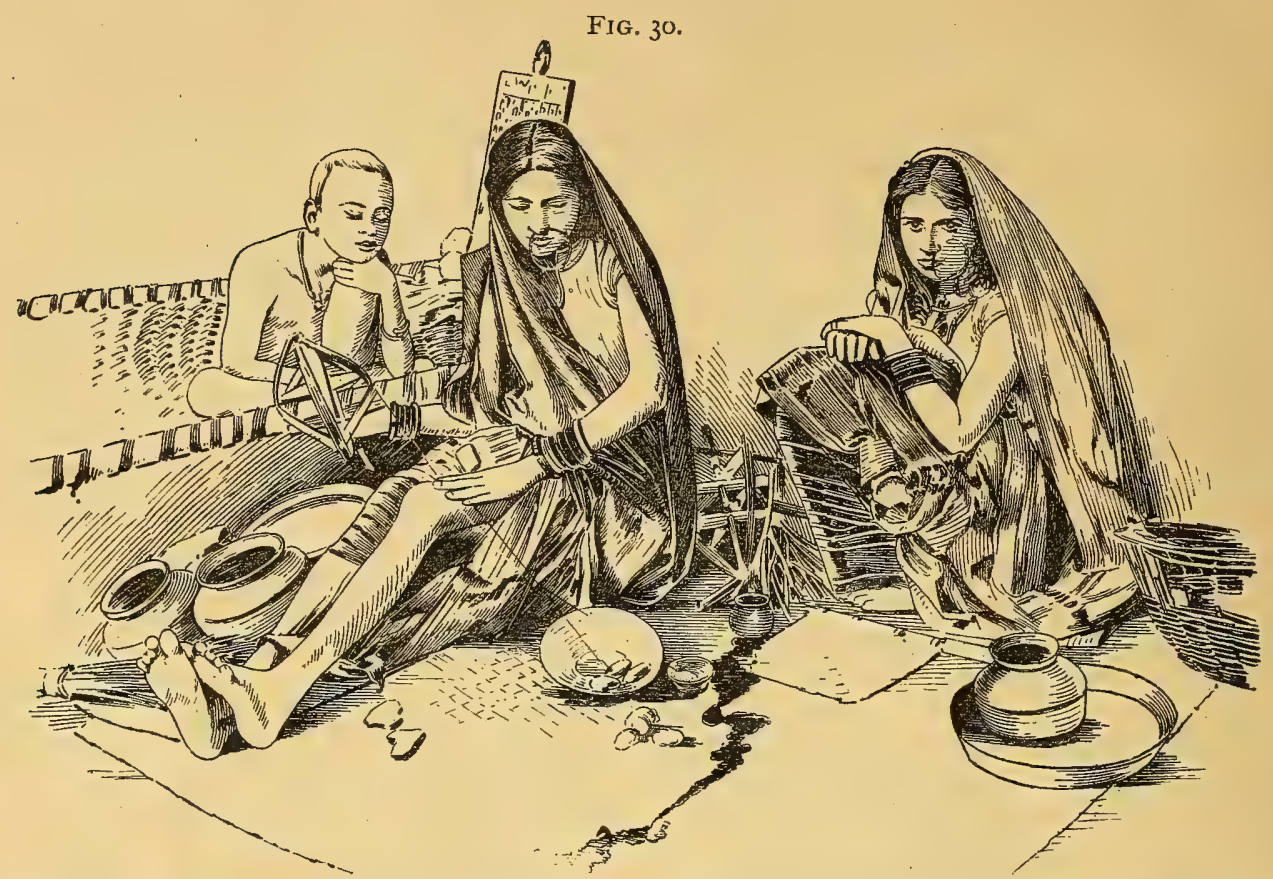

Futwah Silk Women: Mother, Daughter, ani) Daughter's Child; The Mother Reelijg Tussur COCOONS.

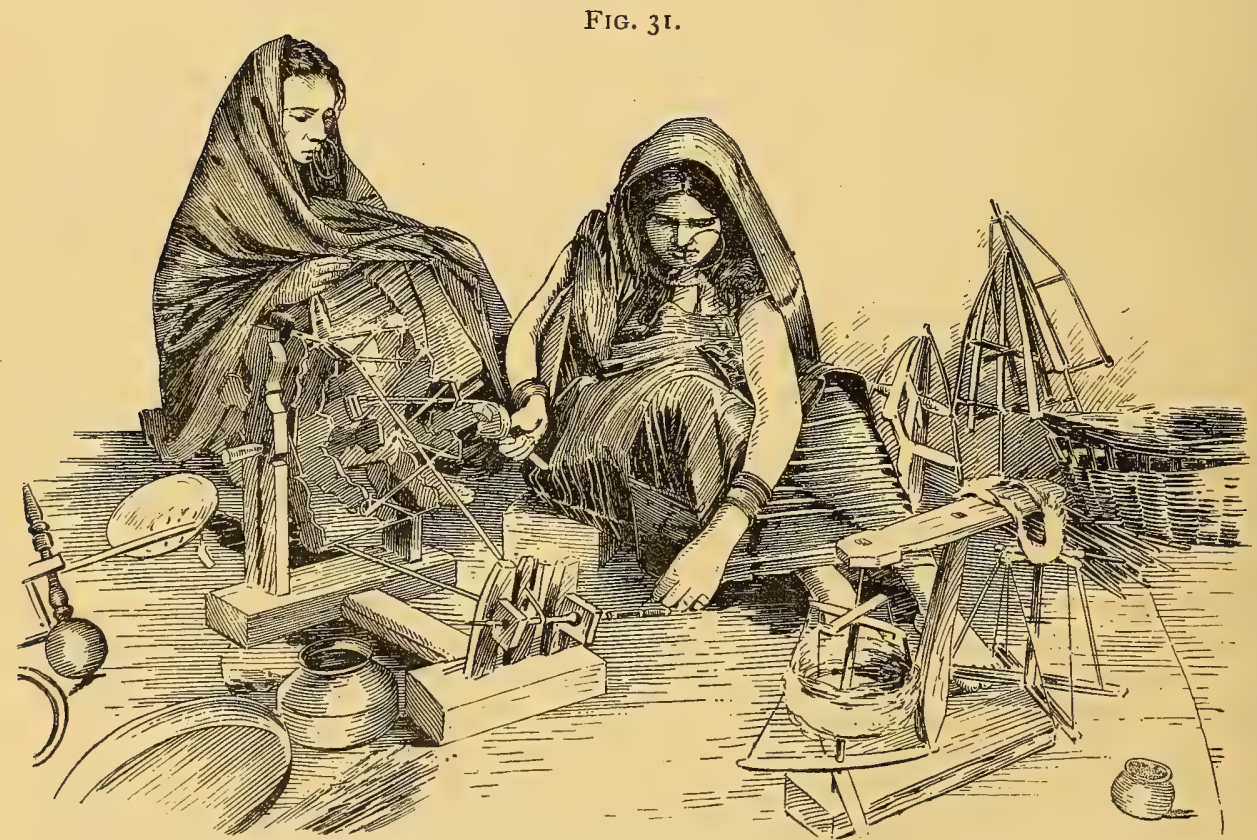

Mo'iher and Daughter: The Daughter Winding Burni, or Whft, from the Hanl)-Reel to Small Shuttie Spools or Squills. 
It is 196 miles from Calcutta. It is celebrated from the prominent part it played in the Mutiny, when a small two-house-made garrison of twelve Englishmen-under Mr. Herwald Wake, an Arrah magistrate, and Mr. Boyle, a civil engineer-successfully and gallantly held their own for a week against 2,000 mutinous sepoys, until they were relieved by Major Vincent Eyre.

I went to Arrah to see some improved reeling apparatus, devised by a Mr. Peppe, an opium duty collector of that place, from whom I received much kindness. $\mathrm{He}$ was trying to establish a tussur cocoon reeling industry there. I need say no more than that I found him producing silk of very good quality; but I thought his system rather less promising than that of the Tavelette Keller(see Fig. 19, p. I4). Mr. Peppe was employing a woman and her daughter whom he had selected from amongst the silk-workers at Fatwah to learn to work his new reeling apparatus; the mother being a cocoon reeler, and the daughter a silkwinder. They very obligingly showed me their native methods of reeling and winding. They are very rude methods, and with very varying and more or less imperfect results. The cocoons are softened with sagi-mutta, an impure carbonate of soda, to which cow dung is sometimes added, and the process is then as shown in my drawing, which is from a photo. graph of the reeler and her daughter, taken at Arrah for me by Mr. Peppe.

Fig. 30 (p. 24) shows the native system of silk winding.

The woman gathers the ends of three, four, five, or six cocoons, according to the thickness of thread required. The ends are fastened to a hand-reel, like Fig. 32, but four-sided, and not flat in its frame-work, which she holds and revolves in her right hand; the threads are drawn off the softened cocoons, which rest on a dish on the floor, after the manner of unwinding a ball of worsted, and, passing over the woman's bare thigh, are rolled into one, by swift rubbing motions down the thigh with her left hand, as you observe in the drawing, and continuously wetting the threads as she rubs them with an astringent soapy decoction of the nuts of Terminalia chebula or myrobalana, which they told me fixes the thread. When the silk is taken off the reel, it is in short, dumpy skeins, like these samples which I saw reeled in this way.

The inferiority of this system of cocoon reeling to that at Behrempore, in the filatures of
Messrs. Louis Payen \& Co., is strikingly shown by comparing these native reeled raw silks with those reeled by their European

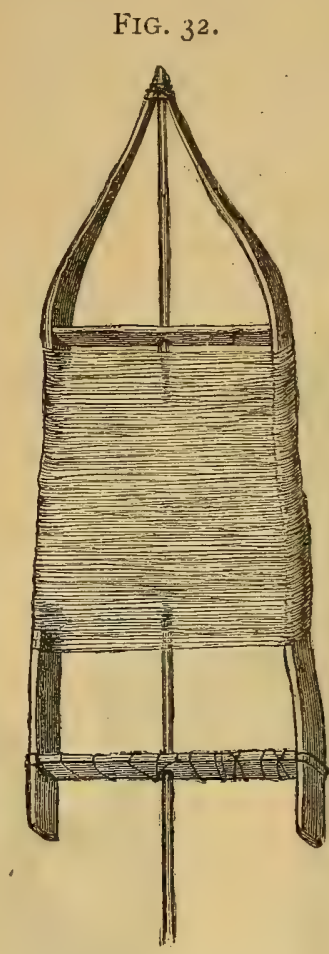

Tussur Hand Reel.

method. Fig. 32 shows the application of the European system of this work.

\section{PATNA AND FATWAH.}

From Arrah, I went to Patna, with Mr. Peppe. Patna is a city, and is situated on the Ganges, a little east of Arrah. It has a population of upwards of $170,000,7+$ per cent. of whom are Hindoos. It is celebrated for the massacre which took place there in 1765 , and for the prominent part it played in the history of the Mutiny in 1857 . The city has a very primitive and un-English aspect, many of the roads or streets being mere mud paths, only three or four feet between the mud houses.

But, as we could find but very little trace of tussur reeling or weaving here, we took train, and went on to Fatwah, a town on the Ganges, of about 12,000 inhabitants, but seldom visited by Europeans. We were told we were the first Europeans who had ever entered the tussur houses. The townspeople regarded us with great suspicion, fearing an interference with their industry. We were followed about by a large crowd, who threw stones into one of the 
compounds we visited, and had it not been for Mr. Peppe asserting his Government authority, I do not think we should have escaped without injury. In one of them we saw the household priest making red and white clay idols, for family worship. Here, I found a considerable tussur trade, and I was much interested with my visit.

I saw the stores of several tussur cocoon merchants, who collected tussur cocoons from the neighbouring jungle villages, and either sold them to reelers, or, as in several instances, employed women to reel them in picturesque single story compounds; with an open square of about ten yards, containing large heaps of tussur cocoons, and bounded on all four sides with sheds or verandahs supported on very handsomely carved teak pillars, in which sat the women, who were reeling the cocoons by hand exactly in the manner shown in the drawing of the Arrah women. After seeing the method, and pointing out to

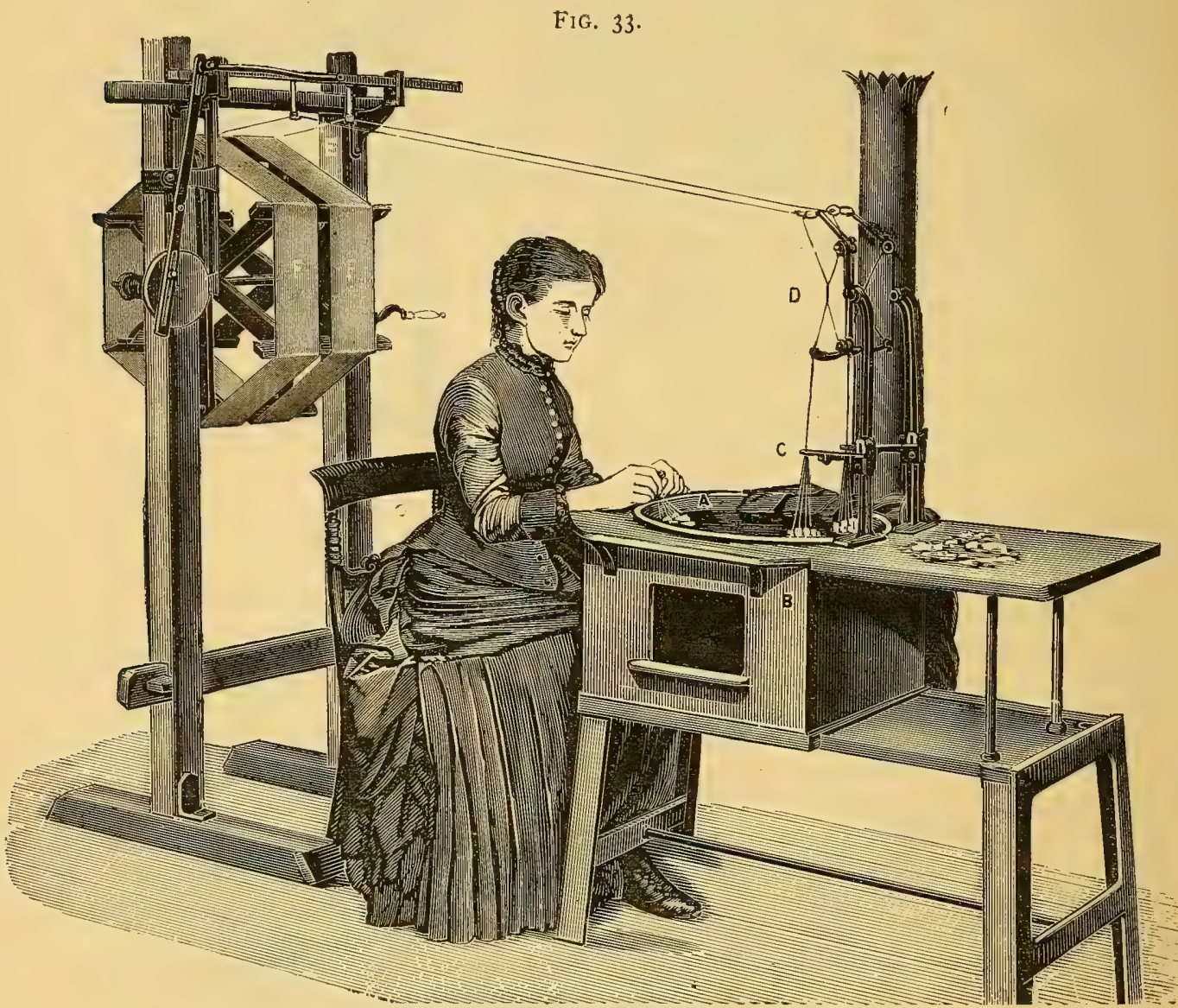

Cocoon-reeling Table (European System).

A. Bassine. B. Furnace. C. Filière. D. Tavelette Keller. E. Winding frame. F. Reel.

the merchants the improved Italian method by the tavelette I took out with me (Fig. I9). I visited the weavers, who were weaving cloths of tussur silk warp and cotton weft. The warp is termed "Tarni," which means to pull, and the weft or shute "Burni," which means to fill. Their narre for shuttle is "Durni." Fig. 34 (p. 27) shows their " tarni " twister, and Fig. 35 (p. 27) their "burni" quills, or bobbins. The cloths are mostly woven in plaids; I bought several pieces. One of the cocoon merchants told us that 25,000 rupees worth of cocoons passes through his hands yearly. The native uses of Indian tussur are various. The cocoons are used in some districts, when cut into strips like peeling an apple, for tying matchlocks, for tobacco-boxes like this one, for jingle bells, as in this woodcutter's knifebelt from the Kolabar district, for Chadars, Dhoti's, and other woven fabrics, wholly or in part tussur, like these from Behrempore and Gaya 
PRESEN'T EuRopean USES OF TUSSUR SiLK.

In describing the present European applications of this jungle fibre, it is necessary to guard myself from being misunderstood. I do not intend "to sing pæons of praise in favour

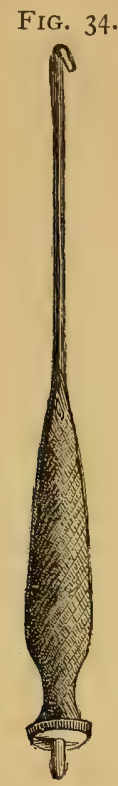

FIG. 35 .
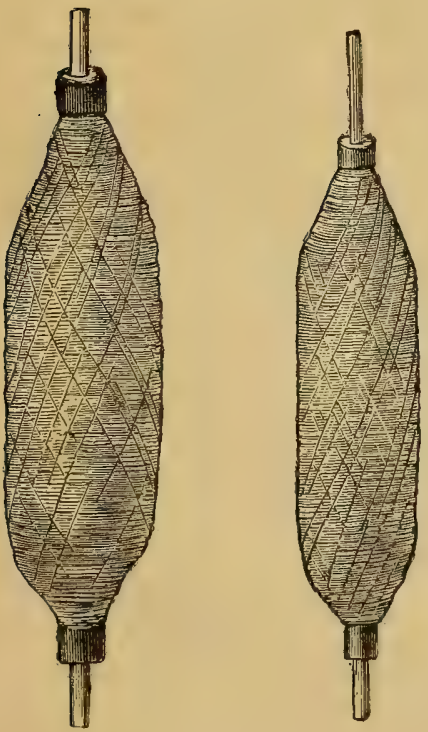

of it, nor shall I praise it for praising's sake. Nor after all these long years of working for it, and of seeing it at last so successfully applied (as I can show you something better than the coarse native woven cloths which I have described and shown), shall I be considered a mere enthusiast. The facts which I have to describe, and to illustrate by t'je interesting series of exhibits before you will speak for themselves, and will assert better than words the splendid results of efforts made by manufacturers in various parts of Europe to utilise this silk, so that it could present itself to good advantage. The truth, however, must and ought to be told about it. A sceptical world must be shown that to those who persevere nothing is impossible. I do not, however, wish it to be considered that I think this wild silk is destined to displace the more refined and beautiful round fibre of the Bombyx mori. It cannot, and if it could, I hope it never would.

But it must be admitted there are many purposes in which, if applied in such a manner as to suit all the requirements demanded of the fabric and by the user, on the score of economy and the prevention of useless expenditure, which is thrift, it becomes a duty to use the less expensive material.

The old prejudices against the utilisation of tussur silk are fast passing away, and manufacturers who looked upon it doubtfully, and even with strong prejudice, a few years ago, are now bound to admit that fabrics spun or woven from the waste of this silk, are products of such superiority and beauty as to have utterly upset their ideas as to what could be produced from it. Take the case of seal-plush alone, and see what a charming product it is. Lighter, more lustrous, durable, and more healthy to wear than sealskin, it is a marvellous fabric. Yet it is made out of the waste, or short ends left from the various operations of the manufacture of tussur silk. It is to tussur silk exactly what spun silk is to the ordinary silk of commerce. It is, in fact, tussur schappe. Here are examples :First, of the reeled tussur; secondly, of the tussur waste; thirdly, of the yarn spun from the raw and from the waste by Messrs. D. and J. Bradwell, Congleton; fourthly, the same yarn dyed; and fifthly, the velvet or plushpiled fabric, so extensively used during the last few years for ladies' over-mantles, and called seal-cloth. It is soft as fur, and quite as durable.

My wife has worn a dolman made of this material for several years, and it is now almost as good as it was at first. Being porcus, this cloth does not repress perspiration, whilst a garment made of skin is not without its dangers. Besides, the skill educed in reeling, spinning, weaving, and the 
cutting of the deep pile which has been brought to such great perfection; besides, the dyeing of it in the piece, afterwards finishing it by elaborate machinery, so that the velvety appearance and the erectness of the pile shall be so perfectly maintained, is most praiseworthy, and I consider it a marvel of manufacturing skill and cheapness. For some time its price was more than $£ 2$ a yard, and even as high as $f 3$, but now tussur seal-cloth of this excellent quality can be bought in the shops at I4s. per yard, 54 inches wide.

So extensive has this branch of industry become in Yorkshire, that sufficient waste tussur could not be procured, and enormous quantities of reeled raw-ilk tussur have been used. Thus, a most surprising anomaly has for the first time in the history of silk-manufacture in any country occurred. Raw silk has been obliged to be purposely made to supply this demand, that is, that tussur cocoons which have been reeled into raw silk have had to be cut up in that state into short lengths like waste, that is, to reduce the length of the fibres from a long continuous thread into short pieces of a few inches only, so that they could be carded and spun like cotton and wool into the yarns necessary to be woven into seal cloth.

So here is a unique example of a silk which, in the reeled state, is worth $4 \mathrm{~s}$. to $5 \mathrm{~s}$. per pound, in order to supply a demand, has to be first reduced to the state of waste, to a value of Is. to 2s. per pound-the price of tussur waste-because of the persevering efforts of manufacturing skill to carry to the furthest limit the utilisation of a fibre which, twentyfive years ago, every one looked down upon with contempt, and condemned as utterly useless; so much so, that I well remember, when I first conceived the idea that, owing to the greater thickness of the fibre of tussur silk, it would be more suitable for pile-stuffs than ordinary silk, and that in a plumose form might be found its most likely destiny and its best application, I applied in vain to several English manufacturers to try it as a velvet or plush, but to no purpose. Each one thought my ideas visionary. The idea of the measuring of the diameter of a fibre had never entered into a manufacturer's head; the furthest his practice would carry him was to discriminate between the various sizes and thicknesses of "raw silk," which, as you know, consists of a bundle of many ultimate fibres. Each one I appealed to turned a deaf or derisive ear to me; some laughed at me; others said it was quite impracticable to make anything of that rubbish, it had often enough been tried before. But my conviction was not so easily cured. I took a quantity I had dyed black to Crefeld, in Rhenish Prussia. The first manufacturer said he had tried before; it was no use attempting to weave it into velvet. I went to another, and asked him if he would manufacture it into a velvet for me, and I would not only be content with the result, however it might turn out, but would pay him for manufacturing it.

The result, for a first trial, was highly satisfactory, and I have here a small piece of this original product. At the Paris Exhibition and afterwards, Sir Philip Cunliffe-Owen was taking an interest in my efforts, and he placed this piece in the South Kensington Museum, where it has been for many years. He also had it placed, with other utilisations of tussur and other Indian wild silks, in the Indian Section of the Paris Exhibition of 1878 . I believe this specimen of tussur-silk velvet, or plush, to be the first plumose fabric ever made from this species of silk. It was made about the year I $\overline{8} 72$.

Very soon after, the Yorkshire spinners took it up. One firm, seeing my Crefeld example in the South Kensington Museum, wrote to me that he did not believe it was tussur silk, and asked me for a pattern of it, saying if it was really tussur silk they could use large quantities. I sent them one, and in a few years they had made a prosperous business in the manufacture of seal-cloth.

Tussur silk has properties superior to ordinary silk for plush purposes, where length of pile is required. Ordinary silk is too soft, and the pile flattens with the touch. This is simply owing to the respective sizes of the fibres, Tussur silk fibres, as I have already stated, are about the 75 oth of an inch in diameter, whilst that of the Bombyx mori of commerce is the 2, oooth of an inch.

The strength of the bave or double fibre of tussur silk is $12 \frac{3}{4}$ drams, with a tension or elasticity in a foot of $4^{\circ} 4$ inches. The strength of the bave of Italian silk is $6 \frac{3}{4}$ drams, the tension or elasticity 36 inches.

I remember the prejudices the tradesmen formerly had against its introduction. Some years ago I went into one of the principal shops in Regent-street, to purchase some tussur seal-cloth. I was told the demand for it was very limited, and that it would never prove a success; they had discontinued buying it because one lady had bought a cloak of it from them and had returned it, saying that she found that her husband putting his arm round her 
left the impression of his arm on the plush. I replied that my wife had worn one for some time and $\bar{I}$ had never noticed that defect, although I had been guilty of the same practice. I said I thought the impression left was on the heart and not on the garment.

But a widespread introduction of it soon followed, notwithstanding that supposed fatal objection, and its use became world-wide, and it is really a fabrique de luxe, and a beautiful example of the triumph of manufacturing skill and perseverance. The continuity of its use varies of course with fashion ; but it is astonishing to gather from silk statistics what an enormous quantity of the waste and raw of this silk has been consumed for this purpose, waste, which $\mathrm{Mr}$. Clayton, a large Halifax spinner, stated in this room in 1879 , at the discussion on my paper on "The Wild Silks of India," lay, four or five years before this date, in the Lower Thames-street Docks as a useless and untried product, and no one would look at it. From thence it was taken to Manchester, where it lay neglected for two or three years, when he accidentally came across some samples of it, and ultimately succeeded in spinning it into yarn, from which was made the seal-cloth $I$ have been describing, which, at the time Mr. Clayton was speaking, had become so much in demand as to cause him to say at that meeting, that as the China supply had ceased, there being not a bale left, unless those interested in Indian produce could cause the waste to be collected there, the industry would die out for want of raw material.

With regard to the substitution of reeled tussur for tussur waste for seal-cloths and their values, Mr. H. T. Gaddum gives me the following information which is worth recording :-

"Up to the last months of 1883 tussah waste silk was worth from $6 \mathrm{~d}$. to Iod, per $1 \mathrm{~b}$., and was made into a low-priced yarn for the manufacture of a variety of different goods requiring a glossy, cheap silk. When the import began I do not know. About the period indicated, it was found that with this material a very good imitation of the material sealskin could be produced, and a large demand for it at once arose, causing the price to advance from Iod. to $2 \mathrm{~s}$. 3 d. This great advance was followed in the succeeding two years by a reaction to about Is. $6 \mathrm{~d}$., but towards the beginning of 1887 , imitation sealskins having come largely into use, especially in America, a sharp recovery occurred, and all the material obtainable found ready purchasers at from 2s. 9 d. to 3 s. 3 d.

"The stocks both here and abroad were cleared out towards the close of $188 \%$. Tussah nett silk having declined to 4 S., it was discovered to be at this price cheaper than the waste, and it came in consequence largely into use. It was driven up to about $5 \mathrm{~s}$. to 5s. $3 \mathrm{~d}$. for use as a waste. The production of the imitation sealskins was rapidly overdone, the demand for them at the same time fell off, and prices since then steadily declined, so that the silk is worth today for dressing purposes about $3 \mathrm{~s} .4 \mathrm{~d}$. to $3 \mathrm{~s}$. $6 \mathrm{~d}$., and the waste to Is. 2 d. to Is. 3 d."

Mr. Dennis Bradwell, of Congleton, informs me that tussur raw-silk is of late preferred to tussur waste by reason of its being less mixed with extraneous matter, and by its giving better results than waste.

But another cause besides over-production had been operating. In the April number of the American Silk Fournal I said, "that of all the various English industries affected by the new American tariff, the seal-plush manufacture, probably, is hit the hardest. This journal's Huddersfield commercial agent represents a falling off in the export of this class of goods to America, amounting to 95 per cent. for the half year ending December 3 Ist, I 890.

I am not going to say that tussur reeled silk is better than the ordinary reeled silk, which nothing yet discovered can surpass, or will ever sur pass ; but there is but little difference in lustre between them; and there are some cases in which tussur silk is made to possess the greater lustre.

\section{EXAMPLES.}

\section{Tussur Pile FABRics.}

Amongst the large series of tussur silk utilisations which I have collected for illustrations to this paper, I wish to direct your notice to the beautiful pile fabrics, seal-plush, seal-cloth and sealette, very kindly lent by several of the principal Yorkshire manufacturing firms :-

Messrs. Norton Brothers \& Co., Nortonthorpe and Cuttlehurst Mills, Huddersfield.

Messrs. Joseph Walker \& Sons, Lindley, near Huddersfield.

Messrs. Field and Bottrill, Skelminthorpe, near Huddersfield.

Nothing in any fibre has ever been made to exceed these. They are wonderfully rich, soft, and glossy.

\section{TUSSUR EMbroIdery SiLK.}

Tussur silk is more lustrous than Japan silk, but not quite so lustrous as China silk. One of its successful uses is for embroidery. This applied use for this silk was found for it, for the first time in its history, I am happy to say, by 
my wife; and this use has every appearance of being as lasting as the silk itself, for it finds an increasing use for artistic work all over the world; yet I am far from saying it is as good for embroidery as the best silk : all I assert for it is, that it is better than spun-silk; and it has an individuality of its own, as you will easily observe all of which, with one exception, are worked in by these beautiful specimens of embroidery, kindly lent by the Leek Embroidery Society, Indian tussur silk. In one of the cases is a collection of Indian tussur silk embroideryfloss, dyed in various colours with Eastern dyes by myself. This will indicate the kind

FIG. 36.
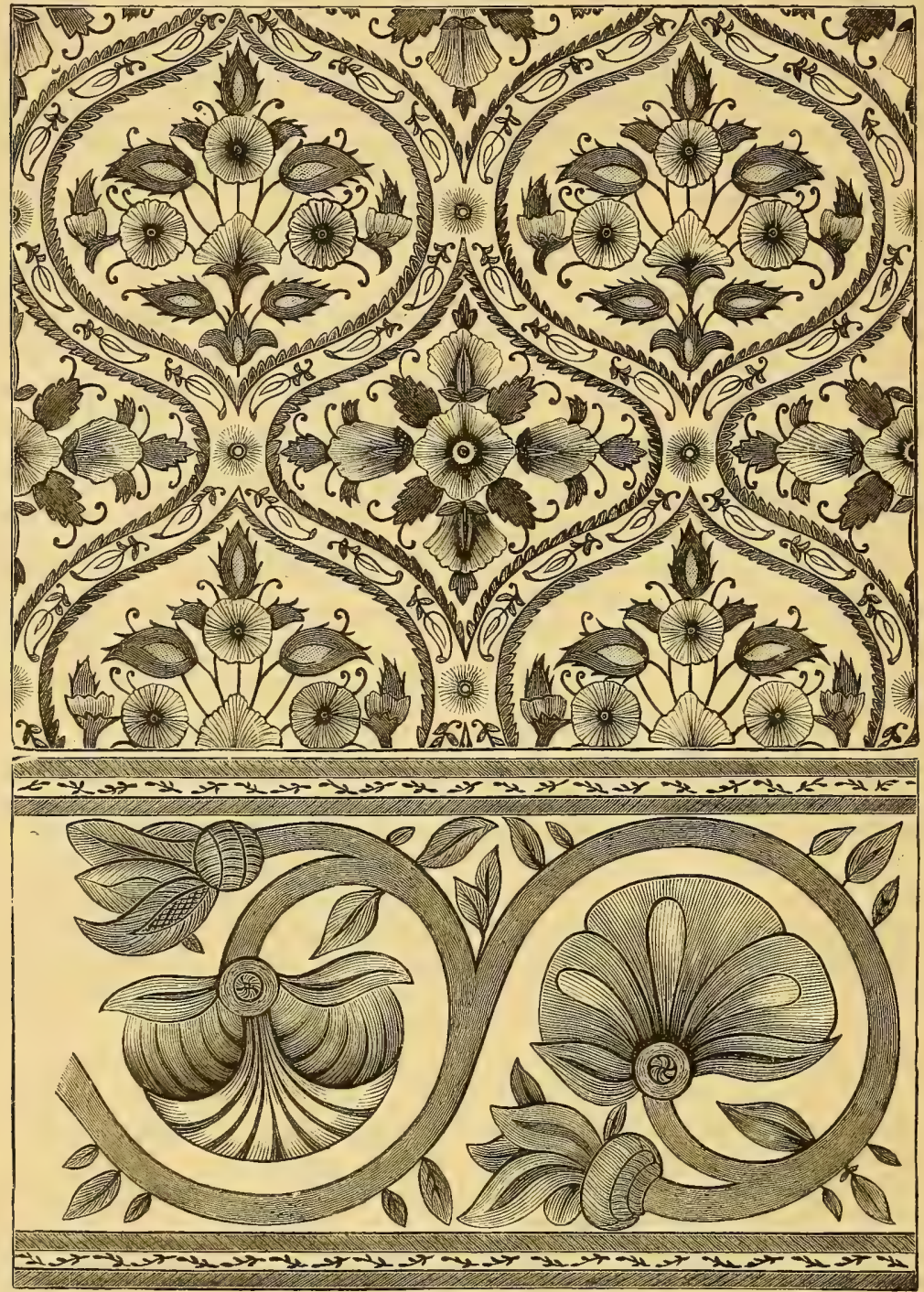

EMbroIdery of INDIAN DESIGNS-LEEK EMBroIJeRY SOCIE'TY.

of thread used by the society, also the colours used. Next to this is a case containing a variety of styles of fringes for embroidery, altar-cloths, and other purposes, entirely made of Indian tussur silk, such as are used by the same society.
TAPESTRY Cloths AND CURTAIN STUFFs.

The employment of tussur silk in England and Scotland, and its successful substitution for ordinary silks for upholstery cloths, or tapestry, as it is erroneously termed, has been very large during the last seven years. It 
admirably lends itself for giving effect and brightness to these goods, which are mixtures of cotton or wool with the floral parts of tussur silk. I believe these manufactures have fallen off with us of late. I find, however, that the manufacture of these fabrics is somewhat rapidly increasing in Lyons, as the extraordinary statistics prove. I attribute the British decadence to the tendency we invariably have in all our manufactures to cheapen them at the expense of excellence and beauty; and to do this, something must be omitted, to make the goods cost less, to satisfy the bargaining of the merchant, and the lamentable price competition almost enforced upon manufacturers. In France, the converse is the case generally. Being an artistic people, they realise the force of Matthew Arnold's words :-

"Art still has truth;

One has only to look at these $\mathrm{v}$ ry beautiful brocatelles lent by Messrs. Kendal, Milne \& Co , of Manchester, the tapestry cloths of Messrs. D. Barbour and Co., the charming and unsurpassed tussur silk brocades of Messrs. Devaux and Bachelard, and Messrs. Lamy and Giraud, both of Lyons, and the rest of this unique collection, which I will briefly describe presently. The large blue, gold, and green curtain exhibited under the arch, is one I had manufactured in Scotland some time ago. The design is the one from the Caves of Ajanta.* The blue and green parts are woollen, and the gold hirds are an enrichment in tussur silk. A complete catalogue of all these will be found at the end of my paper.

\section{TRIMMING MATERIALS.}

The various articles for trimming purposes I have had so kindly lent by their respective manufacturers to me for this paper, prove the superiority of this silk even over any other for these purposes, in the way they are applied, by reason of the natural lustre of the silk, its cheapness, and its greater resistance and firmness in pile.

May I draw your attention to the beautiful specimens of tussur silk utilisations for trimming purposes, such as umbrella-tassels, muffs, upholstery tassel - fringes, parasols, furs, hats and bonnet-tassels for women and children, pom-poms, chenille, dyed tussur silk

\footnotetext{
* This pattern is a reproduction of a portion of the fresco paintings in the caves of Ajanta, in the province of Bombay. These caves were Bhuddist places of worship, and the paintings are admirable for their beauty of design; both borders and subjects being exquisitely drawn. They were painted about 2,000 years ago.
}

on bobbins, \&c., lent by the following tirms:Messrs. A. Kerr and Co., 59, Florida-street, Bethnal-green-road, London, E. ; Mr. A. W. Metcalf, 22, Nicholl-square, London, E. ; Messrs. E. Bateman and Co., Limited, Tottenham-court-road, London. German-Mr. L. Abrahamsohn, Berlin; Messrs. Schlottmann and Co., Berlin; Messrs. W. and G. Kessler Berlin.

Many of these trimmings are very tastefully wrought; some in shaded dyes in chenille; some, chenille and tram alternating, and others, chenille intertwined with bright gimp tussur cord.

Messrs. Anderson, Lawson and Co., of Glas. gow, have sent two most interesting tussur chenille table-covers, with chenille fringes. This is a most recent and important utilisation, as a very large quantity of tussur silk is required for each cover. The surface is very velvety, showing beautiful reflections of light, and the utilisation is certain to become popular.

\section{HANDKERCHIEFS.}

Amongst the rather unlikely uses for tussur silk, I see it has found its way into the pockethandkerchief branch of the silk industry. From Berlin I receive this small lady's mouchoir with border in the approved fashion and embroidered initials. It is remarkably well made, very even in texture, and neither hairy nor hard, and it is, moreover, almost a pure white. It was sent to me by Mr. Maas, and its value is 2s. 3 d.

\section{DRESS SILKS.}

Mr. Maas also sent me these small samples of well-woven tussur thin cloth of various textures, and undyed, he informs me they are used for dust-coats, both for the home and export trade.

I have the following reliable information from Germany. The most important silk manufacturer in Crefeld has tried tussur silk for ladies' dress goods, but when the experiment promised a successful and practical issue, he found out, to his disappointment, that he could not contract with dealers for quantities at settled times, and was thus unable to take orders for goods of fashion, the correct and fixed time of delivery being the most essential condition.

The next is a piece of cream-coloured figured damask, quite rivalling the best weaving of Lyons. It is made wholly of tussur silk, and there is also a specimen of goldcoloured damask of the same pattern, I am 
giad to say of English manufacture. Both of these, made and lent by Messrs. M. Perkin and Sons, 27, Curtain-road, London.

Here are also three excellent and lustrous examples of Indian tussur silk figured damasks, in various colours, in an Indian design. They were woven for me in Leek for my Society of Arts paper in 1879 , and I believe were the first figured fabrics ever made in Europe entirely of tussur silk.

The two French-made open-work damasks, are for light dress purposes, and are of Indian tussur silk.

Detailed lists of these will be found in the catalogue of illustrations at the end of the paper.

\section{TUSSUR CARPETS AND RUGS.}

I have tried successfully the application of tussur silk to carpets and rugs. From its greater thickness of fibre it produces a result between the silk carpets of India and Utrecht velvet. Here is a hand-made example designed by $\mathrm{Mr}$. William Morris, and made for me by his firm. Also several others of smaller size. It is quite as lustrous as the Indian silk carpets, and has a better and firmer pile.

\section{VELVETS.}

Here are several specimens of tussur velvet made recently by Messrs. Devaux \& Batchelard, of Lyons, some of which I have dyed in the piece, and others I have printed. They are admirably suited for furniture velvet, being more lustrous than Utrecht velvet, and not so soft as ordinary silk velvet.

\section{CuRTains AND SHAwls.}

Here are some beautiful woven summer curtains and shawls with very effective borders and centres, manufactured and lent by Messrs. A. Jamieson \& Co., Darvel, Ayrshire.

Messrs. J. W. and C. Ward, of Albion Mills, Halifax, have been obliging enough to lend me two of their light tussur silk summer curtains; both colours and patterns are disposed with great taste.

\section{INDIAN TUSSUR SILK.}

But it is in France that Indian tussur silk to-day finds its greatest market and manufacturing use, and the reason is easy to see. China raw tussur silk is so badly reeled as to be fit only for the coarsest textiles; but since the time I was in India, so much attention has been paid to improving the reeling of this silk at the Behrempore and Surdah filatures, as also at Arrah and at a few other centres, that an Indian raw silk is produced such as can be successfully used for artistic purposes in upholstery by the best Lyonese manufacturers, of whom, probably, Messrs. Lamy \& Giraud and Messrs. Devaux \& Bachelard, and Messrs. Viallar, Guèneau, and Chartron, have been the most persevering and successful. Messrs. Devaux and Bachelard, of Lyons, have kindly lent me two charming specimens of their manufactures, in which Indian tussur silk is used for the weft or shute; the warp is of ordinary silk.

The pale old-gold coloured satin-damask, with pink and pale yellow flowers and graceful other treatment, is one of the handsomest results of weaving and effect in the whole collection. The fabric is very thin, and falls in graceful folds. The other specimen is a thick fabric, suitable for hangings or waistcoats, covered with typical Indian shawl or pear pattern.

In the Exhibition of $\mathrm{I} 88 \mathrm{~g}$, at Paris, my duties in the silk section caused me to notice in it some interesting but plainer fabrics, manufactured by Messrs. Viallar, Guèneau, and Chartron, of Lyons. One of the partners obligingly gave me two specimens which are here exhibited; one is a red plaid, with undyed but bleached tussur ground, the other is a black plaid, with unbleached tussur ground. They have also been kind enough to send me a series of nine other fabrics in which tussur mainly forms the whole. They are, as you see, in plaids and stripes, except one, which is of plush rayé. These fabrics are all manufactured from Indian tussur raw-silk, reeled at Berhampur by Messrs. Louis Payen, filateurs at that place (who inform me they have recently reeled more than 50,000 kilogrammesI $10,000 \mathrm{lbs}$. - of tussur silk), as well as large throwsters in Italy and France. Here are samples of their tussur raw-silk, as clean and almost as fine as Italian silk.

This important filature I found under the able and energetic management of M. Gallois, who was then commencing to reel tussur cocoons. I am informed, from Berhampur, that this firm, since I was there in I 886 , have added three large filatures, and are building a fourth, with a fifth in contemplation, so much has the demand for their Indian tussur silk increased.

And it is from this raw silk that the beautiful fabrics which $I$.am about to point out to you are made. Messrs. Lamy and Giraud have been good enough to furnish me with speci- 
mens of their art-furnishing stuffs, of one metre each. As you see, they are beautiful brocades, of which all, or nearly all, the ornamental parts of flower and foliage treatment are of tussur silk, dyed at Lyons, in very harmonious and rich shades of colour. In those charming brocades, tussur silk is used for the weft. Messrs. Lamy and Giraud inform me that Indian tussur silk gives excellent results in a large range of these fabrics, when properly dyed, the effect being undistinguishable from real silk, especially in the cream grounds. The warp is of cotton, the tram of Indian tussur silk.

Thus you see here at least two most important improvements have been effected, which have elevated the use of tussur silk into a new, an unexpected, and a much more important horizon than that of its Yorkshire uses, of which I have said so much, namely, by improvements in reeling, improvements in dyeing, and its consequent amelioration to permit of its being used by the highest class of Lyons manufacturers.

\section{OPERA-SHAWLS.}

Besides the application of tussur silk to weaving, I am pleased also to be able to show that elegant and effective work can be done in hosiery and lace madufacture. Observe the case of three opera-shawls, or fichus, of machine-knitted or hosiery-made tussur silk, unbleached, manufactured by Mr. Stimson, of Leicester, who is well known for his successful applications of this silk for light shawl purposes.

This silk is made from Indian tussur silk, thrown by Messrs. J. and T. Brocklehurst and Sons, of Macclesfield, who have been kind enough to lend me a bundle of it. It is threethreads organzine, of most excellent quality, and beautifully thrown. It is also used in the exhibits of lace and elastic webs. The Berlin fichu manufacturer has had the courage to go a step further in this direction, by having the tussur silk bleached. This gives a very light and pleasing appearance to the fichus; and I think Mr. Stimson would do well to follow in this direction, especially as it would add to the variety he makes. It is this cream-coloured specimen, and is lent by Mr. IVilliam Mass, of Berlin. The price quoted in Berlin is Ios. I am informed from the same source that tussur silk products are exported from Berlin to America in rather important quantities. It is difficult to ascertain the extent and variety of their tussur silk goods, but it is used for dresses, shirts, pocket-handkerchiefs, dust-cloaks, and shawls, for both home and foreign markets, and also in Saxony, where lace, gloves, \&c., are made of it.

\section{LACE.}

To show how the use of tussur-silk is now beginning to permeate silk manufactures, it is pleasant to be able to bring forward such welldesigned and well-manufactured specimens of lace as those in the two cases I now point out. These are manufactured and lent by Messrs. J. Kirkbride and Co., St. Mary's Gate, Nottingham. All the ornamental treatment has been done with Messrs. Brocklehurst's organzine after being dyed black, its lustrous appearance proving it to be very suitable silk for this purpose.

\section{ELASTIC WeBs.}

Messrs. Archibald Turner and Co., Bow Bridge Mills, Leicester, have also utilised this silk for elastic webs. Here are specimens of their pocket-book and garter webs, which they have kindly lent to me for this paper.

\section{Printed Tussur Silk.}

To show what can be done with tinctorial matter in printing upon tussur silk, I have printed a series of large examples upon native woven Indian tussur silk. Some of them are on bleached grounds, and others upon unbleached grounds. I think you will agree with me that they are not unsuccessful, and are very suitable to be worn for dress.

\section{Dyes in GeM-COLOURS.}

To show the receptivity of tussur silk to tinctorial matter under the present improved methods, I have here a case of fourteen colours dyed by my son to the shades of the principal precious stones, as follows:-Sapphire, emerald, topaz, pink topaz, spinel-ruby, beryl, jacinth, chrysophrase, amethyst, coral, goldquart $z$, turquoise, ruby, peridot.

It will be seen that the difficulties of dyeing this silk may now be considered to have been entirely overcome, excellent results being obtained abroad, by Messrs. Bonnet, Ramel, Sevigny, Giraud, and Marnas, of Lyons, and by other Lyons dyers; by Mr. IV. Spindler, of Berlin, and by most good European dyers, English and Continental.

The two cases below are filled with tussur raw-silk such as is used for the manufacture of pom-poms, dyed by my son with aniline dyes, and contain examples of tussur undyed raw-silk as imported; also after bleaching 
and dyeing into a variety of pale shades suitable for this purpose. There are examples, also, of the purest whites and blacks attainable on this silk.

\section{Embossing with TUssur Silk.}

Here are three bottles of powdered or very finely-cut tussur silk of various colours. This powder, by a patent process, is used for embossing or partially surface-coating it upon plain cloths in the form of figures, flowers, \&c. It gives the cloth the appearance of woven velvet on a plain surface. I have not been able to obtain specimens of the cloth so treated, owing to the novelty and secrecy of the utilisation, but I believe it is in operation at Roubaix.

Here is a fine example of tussur silk plush, embossed or stamped by roller in a very effective and satisfactory manner. No. 36A is another example, but in seal plush.

\section{CONCLUDing OBSERVATIONS AND STATIS- TICAL RECORD OF CONSUMPTION.}

It is thus the dictum of European manufacturers of 15 years ago that tussur silk could never be made anything of, that it would never replace the ordinary silk of commerce, has been returned to them, for here are examples so rich and so beautiful that none but experts could discover what silk they are made of, and it may now be asserted that its day has arrived; that it can and does in a very important degree, for these purposes at least, take the place of the more costly silks of France, Italy, China, and Japan. I never presumed to assert that its mission was to substitute itself for these silks, but I modestly did assert that it would, in time, prove to have distinctive uses, that no fibre comes to us for uselessness, but that with attention uses can be had for all. The triumph of successful tussur silk manufacture is complete. The fibre takes high rank, and can be and now is very largely used to economise the cost of artistic and very beautiful cloths, so as to place them more within the reach of people with moderate incomes, and it has had also this effect, that it has helped to keep down the price of the ordinary silks, and so has permitted them to have a wider distribution. Italian silks are now less than 20 . per pound, and were never known to be so low in price. The Government of France has acknowledged the influence of tussur silk recently, for at a meeting of the committee on French industry, held in Paris the other day, at which M. Fougeirol, one of the ministers of the French Government, and a member of the Chamber of
Deputies, said that tussur silk ought to be taxed, as people were much guided by price, and that was so especially in the increasing use of tussur silk in France, and M. Berenger, President of the General Syndicate of French Cultivators, and Member of the Senate, supported him, saying that so far as tussur silk was concerned, it ought not to be made an exception, it must not be permitted to enter duty free, because to do so would be to increase the use of this silk, which is an inferior sort, and that would be to the prejudice of the French producers.

I hope I may be permitted, with not a little pardonable pride, now to assert the triumphs and gradual progress of this very interesting silk to which I have devoted myself for so many years, sometimes hoping against hope, and at times almost despairing of ultimate success; and in leaving it at this successful stage of its history I wish it further success, and that India may in the long run be the nursing mother of its European requirements.

In 1878 , the Government of India were anxious that the promising developments of tussur silk uses should be shown in the Indian Section of the Paris Exhibition of that year, and requested me to place myself under the guidance of Sir Philip Cunliffe-Owen, in forming an interesting collection. Sir Philip entered into the spirit of the undertaking most cordially, and gave me every help, and, since that time, has shown the greatest interest in this Indian silk; and great credit is due to him for the energy with which he assisted in arresting the attention of the French, in 1878 , and the English, at the Silk Culture Court of the Colonial and Indian Exhibition, in 1886 ; in fact, the success of the increased use of tussur silk is greatly due to him.

He occupied the chair at the reading of my paper on the "Wild Silks of India," in this room, in 1879 , and said, in introducing me, that the evening's subject was one of the practical results of the Paris Exhibition, and that there was nothing which interested the French people more than the collection of Indian silks. He further stated, that the Lyons manufacturers saw the importance of it, and were greatly interested. Since that time, those observations have been attended with abundant realisation, as I will now further proceed to show.

During my jurorship at the 1878 Paris Exhibition, I had many inquiries respecting the vitrines containing the collection of the wild silks of India, from French manufacturers; 
and the cases were frequently opened for their examination. Several were at first disinclined to believe they were really tussur silk, and their doubts were only removed by such personal examination. Monsieur David, the largest ribbon manufacturer in St. Etienne, and also one of the silk jury, said there was no doubt as to a successful futuie for it, and that he could see his way to use very large quantities; and this opinion was expressed to me by several other French manufacturers of importance.

The attention of the French manufacturers was roused, and, very soon after that exhibition, the Chamber of Commerce of Lyons did me the honour to ask me to contribute a collection of tussur silk utilisations, similar to the one exhibited in the Indian Section of the Paris Exhibition. I sent them a very large and specially prepared collection, which they placed in their Industrial Museum, at the Bourse in Lyons, where it now is, and is named the "Wardle" collection. At that time tussur silk found little or no utilisation; to-day the consumption is very large, as I will now proceed to show.

\section{Quantities used Now and Formerly.}

On April the gth of this year, Messrs. Louis Payen and Co. wrote me that the following figures represent the quantities used in Iyons last year :-

The Conditioning House registered for 1890 a total quantity of 306,152 kilogrammes, or 673,534 lbs., of tussur silk, thus divided:Organzine 13,347 kilos or 29,363 lbs.; Tram 69,028 kilos or 151,864 1bs.; Raw Tussur 223,776 kilos or 492,307 lbs.

This is an average of 92 bales of 140 lbs. each per week, and it is confirmed by the Chamber of Commerce published report of last year. Compare this with the whole year of 1879 , when only 53 bales or 7,420 lbs. were imported, and they certainly were not all used.

For the week ending April i ith last, Lyons capped its record. It received and conditioned I 36 bales of tussur silk, or 39,040 lbs., against I 78 bales or 39,160 lbs. of silk of French growth, and 38 bales or 8,360 lbs. of Italian silk for the same week.

For the week ending April 23rd of this year, IIo bales of tussur silk passed through the Lyons Conditioning-house, and generally the average consumption will be close upon 100 bales, or 14,000 per week; it may be a little under or a little over.

Surely this is a most surprising realization of what so recently as 1876 , or 15 years ago, was only an idea, for in that year inly 175 bales reached Europe. I think it will be conceded that it is a consummation which the most ardent imagination could scarcely have been sanguine enough to hope for.

The following Table will explain this statement in a clearer way :-

\begin{tabular}{|c|c|c|c|c|c|}
\hline $\begin{array}{l}\text { Three silks con- } \\
\text { ditioned in Lyons } \\
\text { for the week end- } \\
\text { ing April 9, I89r. }\end{array}$ & $\begin{array}{l}\frac{\dot{y}}{\frac{8}{8}} \\
\frac{0}{0} \\
\dot{0} \\
\dot{z}\end{array}$ & 焉 & 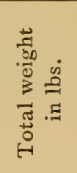 & 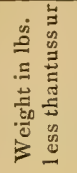 & 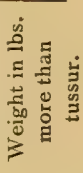 \\
\hline Tussur ..... & 136 & 140 & 39,040 & - & - \\
\hline French.... & 178 & 220 & 39,160 & - & I 20 \\
\hline Italian ..... & 138 & 220 & 8,360 & 39,680 & - \\
\hline
\end{tabular}

Thus the quantity of tussur comes within I 20 lbs. of silk of their own growth, whilst it beats that of Italy by no less a quantity than 38,68 o lbs.

The quantities of the silks of other countries conditioned in Lyons in that week will be found in the official report in the "Bulletin des Soies et des Soieries" for April I8th, I8gI.

Messrs. Louis Payen \& Co. go on to state in their letter " that tussur silks (both Indian and China) are used in Lyons in a great many different sorts of textures, interwoven with other kinds of silk, and wool, and cotton. Trimmings, lace and chenille use it very largely. We send you by post two skeins of our Indian raw silk which we are making ourselves in our Bengal factories in large quantities. 40,000 to 50,000 kilogrammes yearly, or 88,000 to II0,000 lbs., and which we can sell at the following prices :-

$2 \mathrm{I}$ frs. for $30 / 40$ deniers per kilo,, or $7 / 8$ per $1 \mathrm{~b}$.

$20 \mathrm{frs}$. for $40 / 50$ deniers (as the sample) per kilo,, or $7 / 4$ per $\mathrm{I} l \mathrm{lb}$.

I 9 frs. for $60 / 70$ deniers per kilo., or $6 / \mathbf{I}$ I per lb."

These prices are on 90 days' conditions, and free at Lyons.

I have been informed by the President of the Lyons Chamber of Commerce that the consumption of tussur silk and tussur silk waste in France during the latter half of the decade I 870 to $\mathrm{I} 880$ is as follows :-

During 1876,1877 , and 1878 unknown; in fact, hardly any was imported. The Chamber does not know of any. I have also consulted several important Lyons and St. Etienne manufacturers, and they say they do not remember that any branch of the silk trade then required or used any tussur silk at all. 1879-53 bales, or 7,420 lbs. of raw tussur silk; 59 bales, or $8,260 \mathrm{lbs}$. of waste tussur silk. 
188o- 375 bales, or 48,580 lbs. of raw tussur silk; $14 \%$ bales, or $20,580 \mathrm{lbs}$. of waste tussur silk.

The following Table shows the state of the London market in tussur silk from I874 to I880. Compare it with the remarkably increased consumption since the Paris Exhibition of 1878 :-

\begin{tabular}{|c|c|c|c|c|}
\hline Year. & \multicolumn{2}{|c|}{$\begin{array}{c}\text { Stock (Jan. Ist). } \\
\text { Bales. }\end{array}$} & $\begin{array}{c}\text { Imported. } \\
\text { Bales. }\end{array}$ & $\begin{array}{c}\text { Consumed. } \\
\text { Bales. }\end{array}$ \\
\hline 1874 & $66 r$ & .... & none & 168 \\
\hline 1875 & $\ldots$ & $\ldots$ & , & 319 \\
\hline 1876 & .... & $\ldots$ & 427 & $\ldots$ \\
\hline 1877 & $\ldots \quad 428$ & $\ldots$ & 1,037 & 284 \\
\hline 1878 & $\ldots . \mathrm{I}, \mathrm{I} 8 \mathrm{I}$ & $\ldots$ & 837 & $73^{6}$ \\
\hline 1879 & $\ldots . .1,282$ & $\ldots$ & $5^{8}$ & $\ldots . I, I 42$ \\
\hline
\end{tabular}

\section{Chinese Tussur SilK.}

As I have previously stated, the Chinese being quicker to respond to commercial requirements, as soon as they saw the steadily increasing demand for Indian tussur silk in Europe, immediately turned their attention to a greatly increased production of their own article, and to them for some years, say since I 884, has been owing the bulk of the supply of raw and waste tussur silk for European wants.

That India, too, has not been altogether lethargic in an increased output of tussur raw silk, will be shown further on, whilst in regard to Indian native-woven tussur fabrics, she has greatly increased her productions and exports.

To show how much the tussur silk trade has increased in China since 1879 , the following highly suggestive figures will show. They are copied verbatim from the Chinese Customs Report:-

"Shipments of raw silk, waste silk, and pierced cocoons, from the provinces of Manchuria, Chili, and Shantung, for the ten years ending 3 Ist December, I 888 .

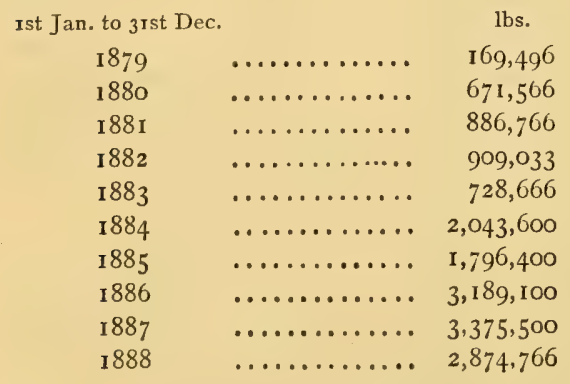

The enormous increase in this business is mainly due to the application of tussur spun silk to the seal and plush trades."
It may be well to place upon record the present values of the various kinds of silks, European and Asiatic, of commerce and tussur silk :-

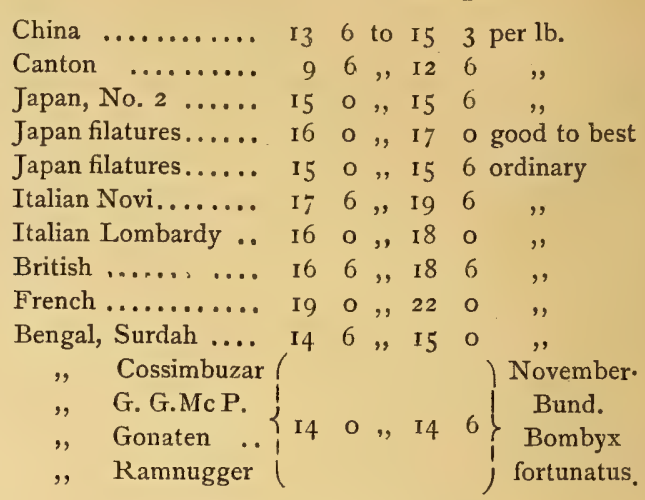

\section{WILD SILK.}

Tussur, Indian $\ldots \ldots, 5$ s. 0 to 7. d.

Tussur, China $\ldots \ldots .38$, 348

Tussur, Waste ...... I 1 I 2 , I 6

Another quotation.... o Io , I $4 \frac{1}{2}$

Tussur pierced cocoons

yielding 70 per cent.

of silk .......... I $9 \frac{1}{2}$, I I I

Tussur Waste, press-

packed for spinning 36

It is very unfortunate that England is so much behind France in silk-trade statistics. I have several times memorialised the Board of Trade, both in my private capacity and also as President of the Silk Association of Great Britain and Ireland, to publish annually the quantities of silk imported of the following kinds :-

Bengal raw silk.

Bengal raw silk-waste knubs, chassum, 8.c.

Bengal corah silks.

Tussur raw silk.

Tussur silk-waste.

Tussur silk pieces.

But they inform me that it would be impracticable to make these distinctions without causing delay in the examination of the goods at the ports. We are also in. the same state of ignorance with respect to the trade particulars of all our silk centres; whilst in France, Germany, and Switzerland all particulars are published yearly, and can easily be referred to.

The Lyons statistics show a rapidly increasing consumption of $I_{50,000} \mathrm{lbs}$. of Indian tussur for last year for that city; but further 
than this I am without information. The consumption in Switzerland and Germany is considerable, whilst in the United States of America it has been very large; one house there was using 2,000 lbs. per week at the time of the Colinderies Exhibition.

\section{INDIAN AND OTHER WILD SILKS.}

I hope I have not wearied you with this tussur silk recital. It is an industry in deep water, and in taking affectionate leave of it I would say that there are yet other wild-silk worlds to conquer, and if I am spared I hope to turn my attention to at least one of three kinds of Indian silks not yet used in Europe, which are capable of having an important future. I need only mention the Eri and Muga silks, long extensively cultivated and used in Assam; the products of the caterpillars of Attacus Ricini and Attacus Assama; the Atlas silk of the Attacus Atlas, the largest known moth.

I found the atlas silk utilised in the Nepal Terai by the Mechi people, in the form of the rudely made cloths, of which I have brought two extremely rare and almost unknown kinds. The warp and weft are hand-spun yarns of long staple. Owing to the oppression the native weavers of this cloth have had to undergo at the hands of the Nepalese authnrity, they have lately been driven from that part of the country bordering on the Mechi, and have settled on land across the Teesta.

Here is also another piece made from the same silk, but showing the native dyeing in the red stripes.

They were first exhibited in the Colonial and Indian Exhibition, and are more fully described, with all other kinds of Indian silk, in the exhaustive and descriptive catalogue of the Silk Culture Court, a book which ought to be in the hands of every European silk manufacturer.

I would especially mention Muga silk, examples of which are before you in all stages. It is even superior to tussur, and is more amenable to dyeing. It only wants bringing to the front for utilisation and increased production.

\section{MANIPUR SILK.}

Hiere is a piece of silk which at the present moment is of interest, but the interest is of a melancholy kind. It is made by the natives of Manipur for the use of their richer people. It is in stripes with broad redpatterned border.
LA Sole Chardonnet-LA SoIE ArtiFicielle : ARtificial Silk.

During my Jury duties in 1889 at the Paris Exhibition, I came across an entirely new kind of fibre, invented by Count de Chardonnet, who terms it artificial silk. But little was thought of it at the time, but it has subsequently been brought to greater perfection, as you will see from the examples I have thought right to bring up with my other illustrations, and it may be of interest to some present. It is a product which belongs neither to the animal nor to the vegetable kingdom, but is purely an organic chemical substance, formed from cotton or cellulose after conversion into guncotton, and from that state into collodion, from which viscous substance it is drawn up as a fine thread by a reel through a glass tube into which water is injected, which immediately hardens the fibre, when it assumes the appearance of silk, which it very much resembles, as far as lustre is concerned. It will, no doubt, command some kind of utilisation, although it can never replace silk, which is much more durable and strong. It is, nevertheless, a deeply interesting and cleverly - devised product. It is protected by several patents; and a company has been formed in France, and one is about to be formed in England. Whatever success it may have in the future, one thing is certain, that its greatest rival will be tussur silk, which can successfully compete with it in price.

Here are two cases of it: one containing it in skeins, dyed in various colours and black, by my son, who has recently found methods of dyeing it without impairing its curious lustre. The other shows it in the state of two kinds of silk damasks, the weft of them only is artificial silk, the warp being real silk, and, in a small piece of ribbon, the figured part of which is artificial silk, and the rest of real silk.

\section{LIST OF THE ILLUSTRATIONS AND}

\section{UTILISATIONS OF TUSSUR SILK.}

I. Entomological glass case of arranged moths, larvæ, cocoons, and silk:- $a$. Larva of tussur silk moth, Antheræa mylitta; $\delta$. Male and female moths of Antherea mylitta; $c$. Cocoons, whole, pierced and showing chrysalides; d. Tussur raw-silk, native reeled at Fatwah e. ditto, reeled by the Italian method by Messrs. Louis Payen and Co, at Behrempore; $f$. Male and female moths of the Chinese tussur silkworm, Antheræa pernyi; $g$. Co. 
coons of tussur silkworm, Antheræa pernyi; ditto, in oak leaves; $h$. Chinese reeled silk of tussur silkworm, Antheræa pernyi ; $i$. Larva of Bombyx mori; $j$. Male and female moths of Bombyx mori; $k$. Cocoons of the mulberryfed silkworm, Bombyx mori, Italian, white; $l$. Ditto, yellow; $m$. Hot-weather cocoons, Bombyx cræsi, and cold-weather cocoons, Bombyx fortunatis of Bengal.

2. Large diagram of larvæ, moths, and cocoons, natural size and enlarged, and raw-silk:$a$. Tussur silkworm or larva; $b$. Tussur moth, Antheræa mylitta; $c$. Tussur cocoon showing pedicular attachment ; $d$. Chinese tussur moth, Antheræa pernyi; $e$. Chinese tussur cocoon; $f$. Mulberry-fed silkworm of commerce, Bombyx mori; $g$. Bombyx mori moth.

3. Large drawing of native Arrah woman reeling and winding tussur silk by their native methods.

4. Large drawing of the European method of cocoon-reeling with the Italian Tavelette Keller.

5. Diagram of the microscopic appearance of tussur silk fibre, longitudinally and in section. Ditto, ditto, showing separated fibrillæ.

6. Ditto, ditto, of the ordinary silk of commerce, Bombyx mori, longitudinally and in section.

7. Five bottles containing silkworms in spirit:$a$. Larva of Bombyx mori; $b$. Larva of the tussur moth, Antheræa Mylitta ; $c$. Larva of Cricula trifenestrata; $d$. Larva of the eri moth, Attacus ricini; e. Larva of the muga moth, Antheræa Assama.

8. Grape-like clusters of the cocoons of Cricula trifenestrata, from Ranchi, Chutia Nagpur, Bengal.

9. Three hand-reels, used by the natives for reeling tussur cocoons. One hand-reel, used by the natives for reeling ordinary cocoons.

10. The Italian Tavelette Keller.

I I. "The Dyes and Tans of India," by T. Wardle.

12. Map of India.

13. Tussur silk dyed black, showing scintillations.

I4. Convoluted flat tape of tin-plate do, do.

I5. Cylindrical rod of the same material, showing equal diffusion of light.

16. Native-woven piece of Indian tussur silk-cloth, undyed. Ditto, ditto, dyed at Hazaribagh, Bengal.

17. Thirty cards, containing samples of woven silk, tussur silk, wool, and cotton, dyed with Indian vegetable dye-stuffs.

18. Santal bow and arrow.

19. Hortus siccus of the tussur food.plants, with tussur cocoons attached to the branches, collected and mounted by the Rev. A. Campbell in the Santal jungles in Gobinpore, Manbhum :- $a$. Terminalia tomentosa ; $b$. Terminalia chebula; $c$. Terminalia arunja; $d$. Terminalia bellerica; $e$. Shorea robusta $f$. Zizyphus jujuba; $g$. Lagerstroemia parviflora; $h$. Careya arborea; $i$. Diospyros tomentosa ; $j$. Alstonia scholaris.

20. Tussur cocoons from the Santals at Pokhuria.

21. Tussur cocoons from Gaya.

22. Tussur raw silk from Gaya, two qualities.

23. Tavelette Keller.

24. Three hand-reels.

25. Hanks of native reeled raw tussur silk, reeled in Arrah.

26. Samples of tussur raw silk reeled by Messrs. Louis Payen and Co., at Berhampur.

27. Fatwah tussur cocoons.

28. Fatwah plaid cloth made of tussur silk warp and cotton weft.

29. Tobacco box of tussur cocoons.

30. Woodcutter's knife-belt with jingle-bells of tussur cocoons.

31. Tussur silk waste for seal-cloth manufacture; tussur raw-silk used for cutting up for sealcloth.

32. Tussur silk spun into yarn for weaving into sealcloth; three sizes, dyed and undyed, manufactured, and lent by Messrs. J. Bradwell and Co., silk spinners and merchants, Congleton.

33. Seal plush.

34. Six kinds of tussur silk seal-cloth, plain, rayé, and embossed; manufactured and lent by Messrs. Norton Brothers and Co., Nortonthorpe and Cuttlehurst Mills, Huddersfield.

35. Five kinds of tussur silk sealettes, manufactured by Messrs. Joseph Walker and Sons, Lindley, Huddersfield : $-a$ and $b$, two kinds of bronze sealettes; $c$, bronze ecrase; $d$, black ecrase $e$, stripe beaverette.

36. Two kinds of tussur silk seal-cloth, manufactured by Messrs. Field and Botterill, Skelmanthorpe, near Huddersfield: $-a$, stamped; $b$, with white hairs inserted.

37. Plush made in Crefeld in $187^{2}$, the first application of tussur silk for a pile fabric, lent by the South Kensington Museum.

38. Embroideries in tussur silk, worked and lent by the Leek Embroidery Society ; $a$. Dinner-table centre on satin, worked in Indian tussur silk, designed by the late John Sedding; $b$. Portière on cotton velvet, designed by $T$. Wardle, jun., and worked in tussur embroidery silk c. Portiere on tussur silk, worked in tussur embroidery silk ; designed by William Morris ; $d$. Panel or screen, worked on native woven Indian tussur silk, in tussur embroidery silk; $e$. Embroidery for cushion, worked on tussur, in tussur embroidery silk, $f$; Tea-gown on tussur, worked in Indian tussur silk; $g$. Design for curtain on cotton velvet, worked in Indian tussur silk; $h$. Embroidery for tea-gown on tussur, worked in tussur embroidery silk; $i$. Curtain border on tussur silk; designed by 
G. G. Scott, jun. ; j. Portière, "Ajanta" design on tussur silk, worked in tussur embroidery silk.

39. Eria silk cloth, English woven; printed by Thomas Wardle.

40. Cloth made of muga silk (Antheræa Assama).

4r. Bengal raw silk, Io deniers, reeled from Bengal cocoons with the Tavellette Keller.

42. The first English-woven piece of silk from muga cocoons; printed by Thomas Wardle.

43. Muga raw silk (Antheræa Assama), reeled in the Colonial and Indian Exhibition, $\mathbf{I} 886$.

44. Tussur silk reeled at Fatwah.

45. Four specimens, of I metre each, of brocades, the ornamental parts of Indian tussur silk, woven in patterns of Louis XVth and Louis XVIth styles; manufactured by Messrs. Lamy and Giraud, Lyons.

46. Tussur plain cloth of excellent quality for underclothing, very agreeable to wear; manufactured by Messrs. Lamy and Giraud; width $27 \frac{1}{2}$ inches, value 5 s. per yard.

47. Brocatelles, or tapestry-cloths, of French manufacture, lent by Messrs. Kendal, Milne \& Co., Deansgate, Manchester:- $a$. Brocatelles, spunsilk warp, with the whole of the weft of Indian tussur silk ; $b$. Brocatelle, spun-silk warp, with the weft of Indian tussur silk and cotton; c. Brocatelle, cotton warp and Indian tussur silk weft ; $d$. Brocatelle, spun-silk warp, with the whole of the weft of Indian tussur silk.

48. Tussur silk tapestry-cloths, for curtains, manufactured by Messrs. David Barbour \& Co., Renfield-works, Pollokshaw, near Glasgow.

49. Five pieces of tapestry-cloths, for curtains, the weft of which is of tussur silk of French manufacture.

50. Blue gold and green curtain, of Scotch manufacture, Ajanta design; the gold-coloured parts are of tussur silk.

5I. Two examples of tussur tissues, manufactured by Messrs. Villar, Gueneau \& Chartron, of Lyons, in plaids also; one other patterned fabrics, in which tussur forms the whole, manufactured by the same firm.

52. A series of summer curtains and a shawl, manufactured and lent by Messrs. Jamieson \& Co., Darvel, Ayrshire:-a. Gold, green, and salmon-coloured summer curtain of tussur silk, beautifully woven, with very effective border and centre; $b$. Gold and salmoncoloured summer curtain, interwoven with muslin; c. Light richly-coloured shawl.

53. Two tussur silk summer curtains, manufactured by Messrs. J. W. \& C. Ward, Albion-mills, Halifax.
54. Small example of gold-coloured damask, manufactured by Messrs. M. Perkin \& Sons, 27, Curtain-road, London, E.C.

55. Example of cream-coloured, figured damask Indian tussur silk, manufactured by Messrs. M. Perkin \& Sons, 27, Curtain-road, London, E.C.

56. Three samples of Indian tussur silk figureddamask, woven in Leek, in 1879.

57. Two specimens of French made open-work dress damasks, Indian tussur silk.

The following articles, included in No. 58 to 62, are manufactured and lent by Messrs. Schottmann \& Co, Berlin :--

58. Woollen shawl, with rich effect with tussur silk.

59. Woollen shawl, with open net-work of tussur silk.

6o. Machine-knitted salmon-coloured fichu, with alternating wavy lines of tussur silk and wool.

6I. Two tussur fichus, in brown and drab, all tussur silk.

62. Tussur silk chenille, in various colours, and cut in a variety of patterns.

63. Pom-pons, tussur chenille, upholstery, tassel fringes, manufactured by Mr. A. W. Metcalf, 22, Nichol-square, London; dyed by Messrs. Joshua Wardle and Sons, Leek.

64. Collection of furniture fringes, upholstery fringes, and curtain fringes (tussur silk), manufactured by Messrs. E. Bateman and Co., Limited, Tottenham-court-road, London.

65. Tussur silk cords and pom-pons for trimmings, umbrellas, children's hats, ladies' dresses, manufactured by Mr. L. Abrahamsohn, Berlin.

66. Assortment of coloured tussur pom-pons, made by Messrs. A. Kerr and Co., 59, Floridastreet, Bethnal-green-road, London, E.C.

The following articles, included in No. 63, are manufactured and lent by Messrs. $W$. and $G$. Kessler, Berlin :-

67. A series of tussur chenilles, chenille fringes, trimmings, tassels, toy monkeys and swans, deep fringes of wool and tussur mixed, and pom-poms, manufactured and lent by Messrs. W. and G. Kessler, Berlin.

68. Tussur silk chenille table covers, manufactured by Messrs. Anderson, Lawson \& Co. ; value, 35s. each.

69. Series of satin damask and brocade of Indiar. tussur silk, manufactured by Messrs. Devaux and Bachelard, of Lyons; I metre each.

70. Six samples of Indian native-woven bleached tussur silk, and three examples of Indian native-woven, unbleached tussur silk for dresses ; printed by Thomas Wardle, Leek. 
71. Indian tussur silk tram, dyed to the colour of fourteen precious stones, by G. C. Wardle, Leek.

72. Indian tussur raw silk, such as is used for the manufacture of pom-poms, dyed with aniline dyes by G. C. Wardle, Leek.

73. A bundle of three-threads organzine of Indian tussur silk, manufactured by Messrs. J. and T. Brocklehurst \& Sons, Macclesfield.

74. Lace, manufactured by Messrs. J. Kirkbridge \& Co., St. Mary's-gate, Nottingham; the patterned part is made of Indian tussur silk, thrown by Messrs. J. and T. Brocklehurst \& Sons, Macclesfield.

75. Three opera shawls, or fichus, unbleached, machine-knitted, manufactured by Mr. Stimsun, of Leicester.

76. Cream-coloured bleached opera fichu, of Indian tussur silk, lent by Mr. Maas, of Berlin; also pocket handkerchief and pieces of tussur silk for rain and dust cloaks, lent by Mr. Maas.

77. Pocket-book and garter elastic-webs, in which tussur silk is used, manufactured and lent by Messrs. Archibald Turner \& Co., Bow-bridge Mills, Leicester.

78. One Io-yard piece of native woven tussur-silk "chadar" undyed, with red border, for women's wear; woven at Giridi, Bengal.

79. One Io-yard length of native woven tussur silk "dhoti," for men's wear; woven at Giridi, Bengal, undyed, with red border.

8o. Indian tussur raw-silk, reeled by Messrs. Louis Payen and Co., at Berhampur.

81. Sample of Indian tussur 2-threads tram, 90 deniers, produced from the above raw silk; thrown in Italy.

82. Scarf of cotton warp and tussur-silk weft ; manufactured by Messrs. Kershaw and Swindells, Macclesfield.

83. Three bottles of powdered tussur silk, for surface coating; a new French utilisation.

84. Native spun and woven undyed cloth, made of the silk of the Atlas worm, Attacus atlas, Nepal terai.

85. Native spun and woven undyed cloth, made of the silk of the Atlas worm, Attacus atlas, Nepal terai ; red plaid on undyed ground.

86. Garment of Manipur silk of native manufacture and dye.

87. La soie Chardonnet, artificial silk, woven into broad silks and ribbons; the warp real silk, and the weft artificial silk.

88. La soie Chardonnet, artificial silk, in skeins, made from cellulose after conversion into guncotton and collodion; dyed in black and colours by G. C. Wardle, Leek.

\section{LIST OF SILK - PRODUCING LEPIDOP. TERA, BROUGHT UP TO THE PRESENT DATE.}

Those marked with an asterisk are in my collection in the imago state. Of those marked with two asterisks I have both imago and cocoon. Of those marked thus ( $t)$ I have the larva, cocoon, and imago. Of those marked thus ( $\dagger \dagger$ I I have the imago, larva, and chrysalis. Of those marked thus ( $\neq$ ) I have the cocoon only. Those not marked I do not possess in any stage, and I shall be glad to receive larvæ and mothes but more particularly the cocoons of all or any of these species to assist me in the investigation of the physical properties and structure of the silk fibres of the Heterocera, a work in which I have for some time been engaged.

\section{CLASSIFICATION}

Animalia.

\begin{tabular}{|c|c|}
\hline SERIES $2 \ldots \ldots \ldots \ldots \ldots \ldots \ldots \ldots \ldots \ldots \ldots$ & Metazoa (Huxley) \\
\hline Sub-Series $2 \ldots \ldots \ldots \ldots \ldots \ldots$ & $\left\{\begin{array}{l}\text { Deuterostomata } \\
\text { a Schizocala }\end{array}\right.$ \\
\hline SUB-KINGDOM 5 & $\left\{\begin{array}{l}\text { Anthropoda } \\
\text { Articulata }\end{array}\right.$ \\
\hline Class $4 \ldots \ldots$ & Insecta \\
\hline ORDER 7 & $\left\{\begin{array}{l}\text { Lepidoptera } \\
\text { Glossata }\end{array}\right.$ \\
\hline $\begin{array}{l}\text { SUB-ORDER } \ldots \ldots \ldots \ldots \ldots \ldots \ldots \ldots \\
\text { Group } \ldots \ldots \ldots \ldots \ldots \ldots \ldots \ldots \ldots \ldots \ldots\end{array}$ & $\begin{array}{l}\text { Heterocera, Moths) } \\
\text { Bombycina }\end{array}$ \\
\hline
\end{tabular}

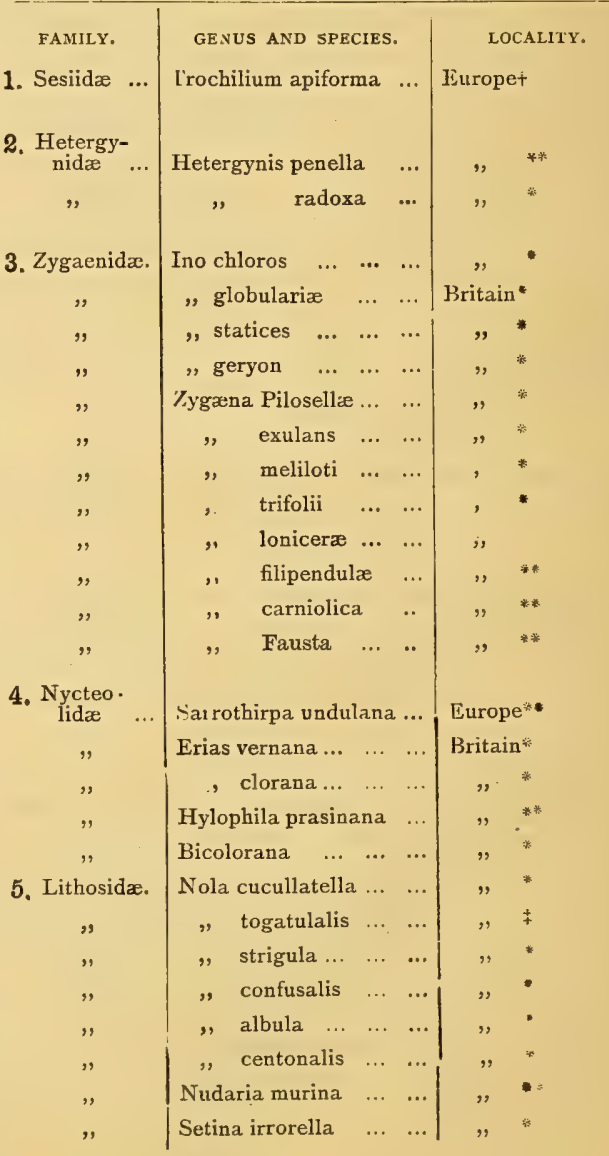




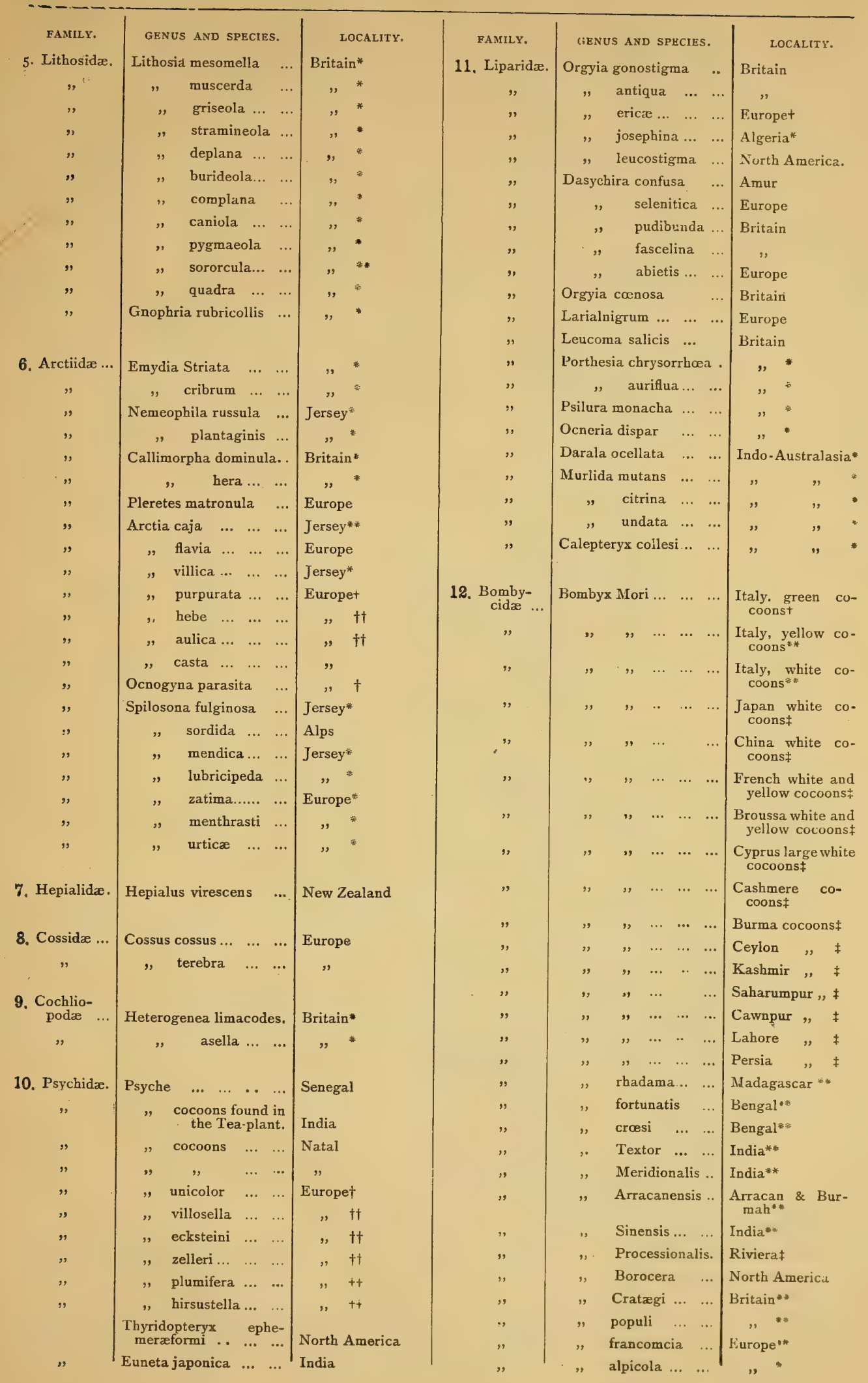




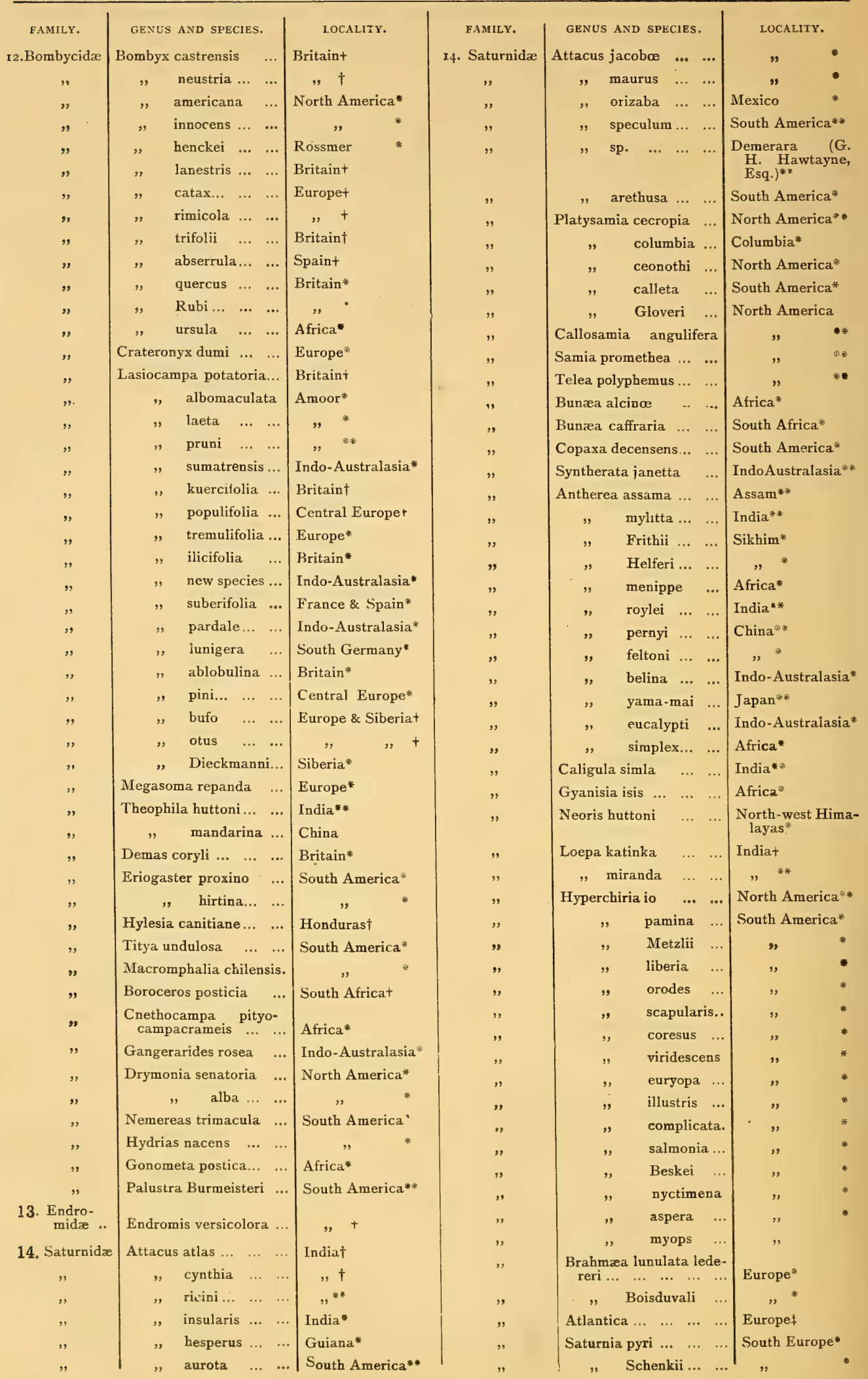


Silk Producers Omitten from the List.

\begin{tabular}{|c|c|}
\hline 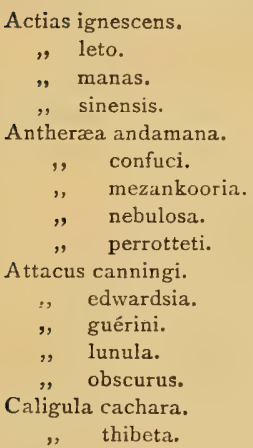 & $\begin{array}{l}\text { Loepa sihkima. } \\
\text { ", sivalica. } \\
\text { Neoris shadulla. } \\
\text { " stolughana. } \\
\text { Ocinara diaphana. } \\
\text { ", lactea. } \\
\text { " moorei. } \\
\text { Rinaca zuleika. } \\
\text { Salassa lola. } \\
\text { Saturnia anna. } \\
\text { " carpini. } \\
\text { Th lindia. } \\
\text { Theophila bengalensis. } \\
\text { " religiosa. } \\
\text { " sherivilli. }\end{array}$ \\
\hline
\end{tabular}





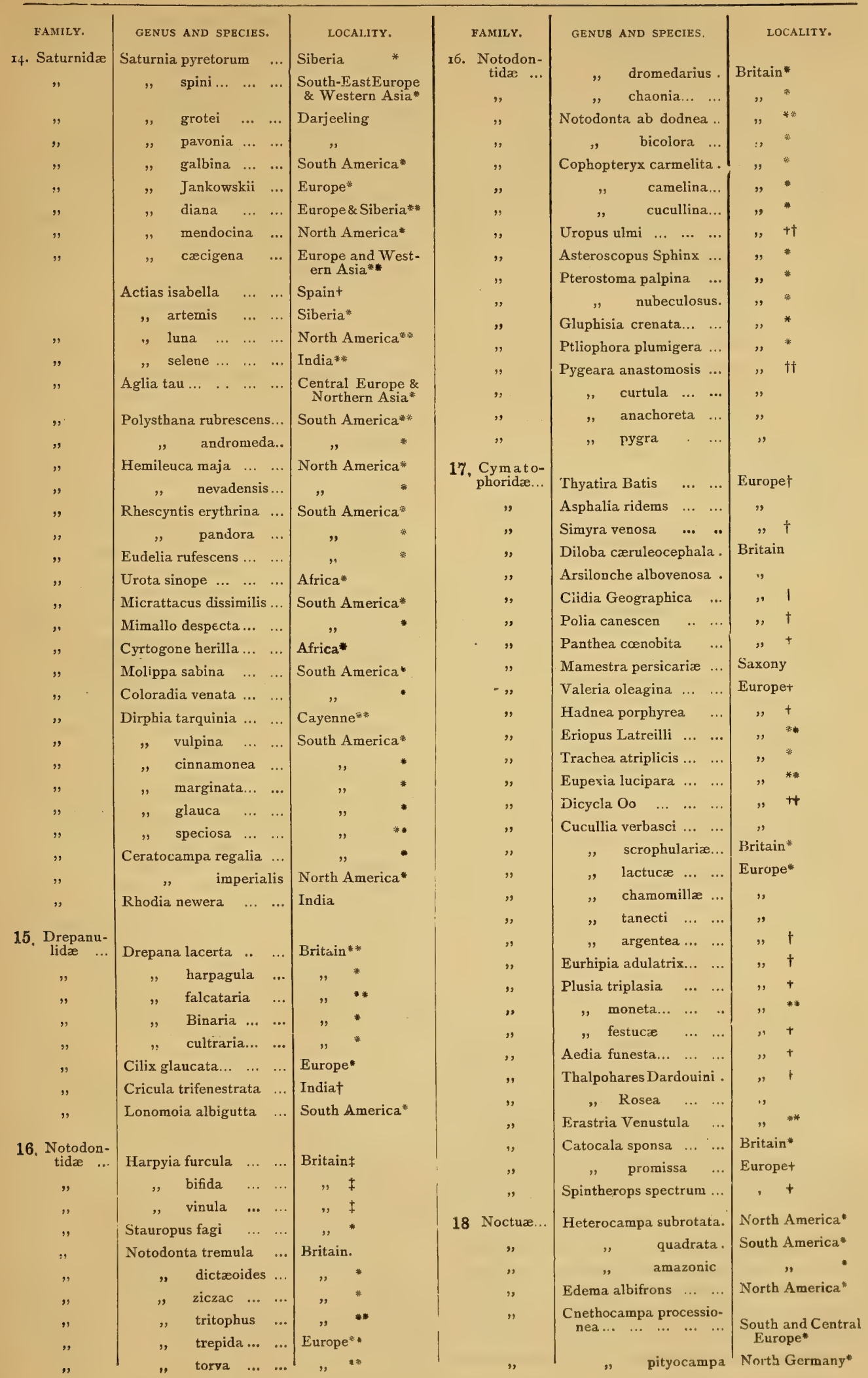




\begin{tabular}{|c|c|c|}
\hline FAMILY. & GENUS AND SDECIES & LOCALITY. \\
\hline I8. Noctuæ... & Cnethocampa pinivora. & Europe** \\
\hline , & ," Herculeana & , * \\
\hline , & Loma orion $\quad \ldots \quad \ldots \quad \ldots$ & Britain \\
\hline , & Diphthera ludifica .. ... & Europe*** \\
\hline , & Acronycta auricoma ... & Britain* \\
\hline , & ", menyanthidis & $" *$ \\
\hline 19. Geometrae & Odontopera bidentata... & Britain * \\
\hline , & Eugonia autumnaria ... & , ** \\
\hline$"$ & Pericallia Syringaria ... & Europett \\
\hline , & Eugonia fuscantaria ... & $"$ "* \\
\hline$"$ & Epione Apiciaria ... ... &,$\quad++$ \\
\hline$"$ & Acidalia Iuteola $\quad \ldots \quad \ldots$ & Britain $\neq$ \\
\hline " & Numeria pulverari $\quad \ldots$ & , \\
\hline ", & Cidaria sagittata $\ldots \quad \ldots$ & $\Rightarrow 4$ \\
\hline , & Eucosmia certata ... ... &,,$\quad \neq$ \\
\hline$"$ & Eupithecia togata ... ... & $"$ \\
\hline 20. Galleriæ . & Galleria mellonella $\ldots$ & $"$ \\
\hline 21. Tortricina & $\begin{array}{lll}\text { Tortrix viridana } & \ldots & \ldots\end{array}$ & , \\
\hline $\begin{array}{r}\text { 22. Talæpo- } \\
\text { ridæ ... }\end{array}$ & Talæporia politella $\quad .$. & Europe ${ }^{* * *}$ \\
\hline " & \begin{tabular}{cccc} 
& \multicolumn{4}{c}{ pseudobom- } \\
bycella $\ldots$ & $\ldots$ & $\ldots$ & $\ldots$
\end{tabular} &,$\quad \dagger$ \\
\hline " & Solenobia clathrell $\ldots$ &,$\quad * *$ \\
\hline , & " peineti ... ... & , ** \\
\hline , & " Iriquetrella. &,$\quad \dagger$ \\
\hline 23. Lypusidax. & Psilothrix dardoinella ... & $\Rightarrow \quad * *$ \\
\hline 24. Tineidx . & Tinea pellionella $\ldots . .$. & $"$ \\
\hline $\begin{array}{l}\text { 25. Hypiono- } \\
\text { meustidæx }\end{array}$ & $\begin{array}{ll}\text { Hyponomeuta } & \begin{array}{l}\text { evony- } \\
\text { mellus }\end{array}\end{array}$ & , \\
\hline$"$ & $" \quad$ plumbellus & $" \quad *$ \\
\hline ", & $" \quad$ padellus... & " * \\
\hline $\begin{array}{r}\text { 26. Peut e l- } \\
\text { lidæ } \ldots\end{array}$ & Cerostoma Denitella ... & $"$ \\
\hline $\begin{array}{l}\text { 27. Pyralidi - } \\
\text { dæe }\end{array}$ & 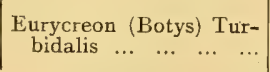 & $" \ddagger$ \\
\hline
\end{tabular}

\section{DISCUSSION.}

Sir George Birdiood said that Mr. Wardle had attributed too much credit to him, in saying that he was the first to draw attention to the possibility of utilising the tussur silk of India in European manufacture. He had simply not neglected his duty with reference to this interesting silk, whether in connection with the Victoria and Albert Museum, at Bombay, and the India Museum here, or the various international exhibitions held since that of 1851. But, long before his time, the capabilities of tussur silk had been noticed by English naturalists in India; and in certain parts of India -in the Deccan, particularly in the valleys of the Kistna and the Godavery, and throughout the Circars to Orissa, and again on the north-western borders of Hindustantussur silk had been woven from time immemorial ; and he was of opinion that the earliest silk known to the ancients was tussur, and not mulberry silk. Dr. Roxburgh, a hundred years ago and more, had, in the seventh volume of the Linnean Society's "Transactions," fully described the preparation of tussur silk in Bengal. But all this had been overlooked and forgotten; and, coming down to our day, it was $\mathrm{Mr}$. Edwin Heycock, * who at the meeting convened by him at Bombay, in $185^{8}$, to commemorate the assumption of the direct government of India by the British Crown, by founding the Victoria and Albert Museum, holding up a tussur cocoon before the assemblage, observed that the great use of the museum would be in bringing to light waste Indian products, such as their neglected source of cheap silk. His apt illustration of the potential benefits to be derived from an economic museum at Bombay was received with unbounded enthusiasm, and the incident having been reported all over the world, from that dramatic moment the wild silks of India were never again lost sight of by the manufacturers of the West; with the result, thanks to Mr. Wardle's enthusiastic researches, and Sir Philip Cunliffe-Owen's strenuous advertisement of them at Paris, in 18,8 , so ably recorded in the paper just read, and further shown in the sumptuous tussur fabrics with which $\mathrm{Mr}$. Wardle has draped these walls. What Mr. Wardle had exactly done in the matter was to make tussur silk merchantable in the same way as mulberry silk, and even to a greater extent; and he had done this by having discovered the means of removing from the fibre of the tussur silk the resinous sheath with which it is naturally invested. Before he had found the means of removing the resinous sheath from it, it would take only certain very dark, not to say lugubrious dyes; but now that, through Mr. Wardle's processes, the resinous sheath can be removed, tussur silk will take nearly every dye that mulberry silk takes, and can be used by manufacturers as widely as the latter, if not more so; for while tussur siik, without its resinous sheath, takes all our lighter dyes, with its resinous sheath on, it still, of course, takes all the darker dyes with which it has so long been associated. There is, therefore, a great and a growing future before it; and it is indeed impossible to exaggerate the importance

* This gentleman was Sheriff of Bombay for $185^{8}$; and he was also the author of a thick duodecimo volume, which went through two or three editions, on "The Exodus of the Israelites out of Egypt," the object of which was to prove from Jewish prophecy that Egypt was predestinated for the English. He was almost singular among the merchants of his day, in Western India, in knowing anything of the country and its people beyond the limits of the town and island of Bombay. Yet a more eminent exception to their ruling ignorance in this respect was Mr. Walter $\mathrm{R}$. Cassels, the author of an invaluable report on "Cotton and its Culture in the Bombay Presidency " [Bombay, I862」; and of a most dainty duodecimo volume of transcendental poetry, entitled, "Eidolon, or the Course of the Soul," published by Pickering, 1850. Mr. Walter Cassels was the brother of Mr. Andrew Cassels, for so many years a Member of the Council of the Society of Arts, and also of the Secretary of State for India. 
of the services rendered by Mr. Wardle to every tussur-producing country of the East. He is certain to be recorded in history as one of their best benefactors, and Sir Philip Cunliffe-Owen's name will always be associated with his in this connection. Unfortunately nearly all the benefit of $\mathrm{Mr}$. Wardle's researches had been taken acivantage of by the Chinese, and not by the people of India, for whom they were expressly undertaken. What the explanation might be he could not say, but a part of it must, he feared, be attributed to the want of commercial enterprise in the people themselves. But still they must benefit by Mr. Wardle's life work in the end. $\mathrm{He}$ was sorry to say anything that might seem harsh of Mr. Wardle on an occasion of so much justifiable congratulation. But in one part of his paper Mr. Wardle had slipped into the error of speaking of the "regular results" he "hoped" would be obtained by improved processes of reeling tussur silk in India. Why one of the accidental artistic qualities which made Indian textile fabrics so "precious" in the eyes of persons of "taste" was dependent on the "irregular results" of the primitive, traditionary methods still followed by the people of India in spinning silk, wool, and cotton. These irregular results gave a surface play of light and shade, the absence of which was one of the most marked defects of mechanical spinning and weaving. It was an extraordinary illustration therefore of inborn perversity that a man of Mr. Wardle's genuine artistic sensibility should praise the anticipated "regular results" of the Italian methods of spinning that are being introduced into India. But he did not mean what he said, and had but slipped with his tongue. It reminded him of a resolution moved at the Indian Congress of 1887 by a Hindu gentlemen, condemning the people of India for going on spinning and weaving in exactly the same fashion as their forefathers 3,000 years ago, as if it was possible to improve on perfection! Again, Mr. Wardle spoke of "ameliorating the natural colour of tussur silk," by scorching it to a leprous white with oxygen. And, worst of all, he spoke of the production of artificial silk fibre from celluloid as "progress." The next step in this sort of "progress" would be the production of celluloid silk in sheets, like "mackintosh." That sort of "progress" was simply damnable. He must, however, unreservedly congratulate Mr. Wardle on his paper, and thank him for the fulness with which he had illustrated it, by the splendid tussur stuffs hung round the room. He must also express his personal thanks to her Ladyship for presiding. It was the first time a lady had presided at a meeting of the Society of Arts, and he sincerely trusted it would not be the last. In conclusion, Sir George Birdwood read a letter from Mr. Lazenby Liberty, expressing his regret at not being able to be present at the meeting and testify personally to his sense of the vast importance of Mr. Wardle's labours in developing the utilisation of tussur silk, and, acknowledging also the great impulse he had given during the last few years to the reviving of silk manufactures of the United Kingdom.

Mr. LEWIS DAY said that he had no claim to speak on the subject, which was more scientific than artistic; but so far as art was concerned, Mr. Wardle had abundintly proved that tussur silk lent itself to beautiful effects of colour, and all artists must be thankful to him for having brought about its introduction. $\mathrm{He}$ agreed with Sir George Birdwood as to the beauty of Oriental dyeing; it was a mistake to try to equalise everything, as British merchants endeavoured always to do. What difference there was between tussur silk and mulberry silk, so far as colour was concerned, seemed rather to the advan. tage of tussur silk. There was a certain tone in the silk itself which helped to qualify the raw colours too frequently used.

Mr. Martin Wood considered that Mr. Wardle had done immense service to India and England, by neutralising its adverse conditions and thus utilising tussur silk, although the Chinese had sent it to this country long before. The examples which had been given of perseverance, and overcoming the essential difficulties of dyeing the fibre, were worthy of all praise. Whilst he had done so much, he (Mr. Wood) should like to point ont another direction in which similar efforts might be taken with great advantage; and that was with regard to the tussur being improved by crossing it with the Japan moth which was similar to the moth described by Mr. Wardle as feeding upon the oak. The hybrid worm produced a very fine silk, it being free from the resinous substance which had prevented tussur silk from being dyed. Mr. Wardle did not wish to displace from its queenly position the Bomoyx mori, but its sway was restrained by the fact that the mulberry tree could not be grown in all parts of India. One advantage of tussur silk was that it was wild and cost nothing to produce; but shortly there would be great difficulty in obtaining it, so the supply would become limited. When that happened, the cost would consequently be increased, and hence arose the necessity for cultivating it. If that had to be done, it would be worth considering whether it would not be better to cultivate the superior moth to which he had just referred. So long ago as I882, and again in I887, he pointed out, in the fournal, that this superior moth could be cultivated in every part of India, and it would fill the place between the tussur moth and the Bombyx mori; for trees suitable for the hybrid moth grow in all parts of India.

Sir Philip Cunliffe-Owen, K.C.B., K.C.M.G., said that he wished more interest were taken in India itself in Mr. Wardle's life-long labours to develop the use of the wild silks of that country. He at first became interested in the subject in the early part of 
I 874 , when he received quite a mysterious visit from Mr. Wardle, who came to him for assistance in the investigations he then commenced on behalf of the India-office regarding the utilisation of tussur silk. Since then, he had closely followed every step in the remarkable developments of Mr. Wardle's labours with ever growing satisfaction; it was, indeed, a cause of pride to him to-day, as he was sure it must also be to Mr. Wardle, to see hung all round this room such a magnificent display of the results of his researches-so fruitful of good to India and China, and carried out in such a wholly disinterested, and, indeed, self-denying spirit by himself. He was especially proud of the part he had taken in the Paris Exhrbition of 1878 , in drawing attention to $\mathrm{Mr}$. Wardle's exhibits on that occasion, when not only was a Grand Gold Medal of Honour given for Indian teas, but a second Grand Gold Medal of Honour for Indian silks. A number of lesser medals were also secured for the Indian teas; and it was these awards which advertised Indian teas and tussur silk all over the world, and the wonderful increase in the use of Indian teas in every part of Europe, and of tussur silk in France since $\mathbf{1 8 7 8}$, was entirely due to these signal awards. The world owed a deep debt of gratitude to Mr. Wardle for his persevering efforts; and he hoped the India-office would translate his paper into French, German, and Hindustani, and scatter it broadcast through Europe and the United States and India. They would, indirectly, reap a rich reward for it.

Lady EGERTON said she had learned a great deal from the interesting paper read by $\mathrm{Mr}$. Wardle, and the way in which it had been illustrated by the different specimens shown must appeal to every feeling. From the cursory inspection which she had made of the silks, they appeared to be very thin. Her own experience of tussur silk was that when made into a dress it fell in irregular folds, and she should like to know from Mr. Wardle whether it could not be manufactured so as, when made up, to fall in artistic folds, the same as mulberry silk.

The vote of thanks to the author having been carried,

Mr. WARDLE, in reply, said some of the fabrics were very thin, and some very thick; but there were a great number of varieties between the two. A fabric, such as that required for the best purposes of dress, would never equal those of the best silk ; but there were a great many purposes for which it could be used, chiefly for furniture silks, and for cloaks and shawls, and even for dress secondary only to best silk; but one of its chief uses was for trimmings and chenille, in which very successful effects were produced, both on the Continent and in England, as these beautiful and artistic samples proved. The silk was naturally harder than the silk of commerce, and always would be. It would scarcely fall in such graceful folds as mulberry silk, but it perhaps might, if judiciously mixed with other silks. The way tussur silk was woven in the crude looms in Bengal was such as to make it harsh; but some of the Lyons specimens which he had brought would fall into excellent folds, as also two specimens of figured damasks, which he omitted to notice, but which he now handed to Lady Egerton; and he was glad to be able to state they were manufactured in London. They were very beautifully made, and seemed to meet every requirement. There were also three shawls on the wall that were made in Leicester, and one made in Berlin, the cream colour in the latter being produced by means of the action of nascent oxide on the fibre. It was most gratifying to him to hear his labours so well spoken of both by Sir George Birdwood and Sir Philip Cunliffe-Owen. Such generous recognition of work was in itself no slight reward; but it was necessary for him, in order to correct any misapprehension which might arise as to the nature of Sir George Birdwood's remarks about manufacturing and dyeing operations, to say that if Sir George had been a manufacturer he would have looked at the question of what he calls "regular results" from an indus. trial point of view. In his present remarks he simply looked at it in an æsthetic sense. With all respect for the artistic side of the question, he must enter his protest against any defence or encouragement of imperfect and slovenly work. The native reeling of tussur cocoons in India was very imperfect; of that there could be no manner of doubt. It surely could not be artistic or æsthetic to pull off a thread from the cocoon, which the worm had deposited in perfect order, in a disorderly rabble, and he would refer Sir George to the remarks in his paper which, for want of time he had been obliged to omit reading, where he referred to cocoon reeling, and to what the French termed duvet. Could it be defended that if a ball of worsted had to be unwound into a skein, that the skein should become a series of tangled rabbles. That was exactly the case in most of the native Indian and China reeling of tussur cocoons. With regard to the bleaching of tussur silk, the same line of defence must be taken up. It was all very well to defend natural results, but everything that had been done in the direction of improving the dyeing of this silk had been done in an artistic direction, inasmuch as both the natural colours of the raw tussur silk of India and China was simply that of a dirty drab, in which state it was not possible even to dye into the warm artistic tones of colour. The Indian people themselves had tried, but for centuries with the worst results. Now that the so-called resinous brown colouring-matter can be discharged, tussur silk can be dyed into those most delicate and beautiful shades of colour which Indian people them. selves love so much to wear ; and it never could have been accomplished without the removal of what is simply a dirty stain. And Mr. Day was in error in thinking that the drab tone of tussur silk aided the effect of applied colour: the very reverse of this was the case. 
In the Zoological Gardens at the present time there were tussur moths and worms in the living state, and Mr. Sclater had sent word to say that these specimens might be seen.

He was very much obliged to Sir Philip CunliffeOwen for the interest which he had always displayed in this matter. And he ought not omit to state in this place that H.R.H. the Prince of Wales, as President of the British Section of the Paris Exhibition of 1878 , also took a deep interest in the exposition of these Indian wild silks, and greatly encouraged their exposition.

In 1879 the shipment of Chinese tussur silk to Europe was 169,466 lbs., but in 1587 it had grown to the enormous figure of $3,375,500 \mathrm{lbs}$. Notwithstanding the great consumption of China tussur he might say that for the whole of 1878 there were only 350 bales of tussur silk conditioned in Lyons, and the whole of this was not used, but for the week alone ending in April, I89I, there were 136 bales of tussur silk conditioned, as against 178 of French and 38 of Italian silk.

No fear need be entertained as to the progress of Indian tussur silk. The more it is known the more it will hold its own. Its strength is one-third stronger than China tussur silk. Indian tussur-silk bave, or the double fibre, in an average of twelve trials of 12 -inch lengths showed a strength 12 drams, and a tension or elasticity of 4.4 inches. China tussur-silk bave, or double fibre, in an average of twelve trials of 12 -inch lengths showed a strength of $8 \frac{1}{4}$ drams, and a tension of elasticity of 5.4 inches, whilst Italian-silk bave, or double fibre in an average of twelve trials of 12-inch lengths, gave only a strength of $6 \frac{1}{4}$ drams, and a tension or elasticity of $3 \cdot 6$ inches.

The vote of thanks to Lady Egerton for presiding having been unanimously passed, the proceedings terminated.
Since this paper was in type, the Lyons Conditioning House has reported the return of tussur silk conditioned for the week ending July $4^{\text {th }}$, of the immense quantity of 220 bales, or 38,000 lbs., thus more than doubling, by 30 bales, the average weekly quantity of last year.

This shows that public attention both in India and the rest of Europe cannot be too strongly called to the importance of this question. 





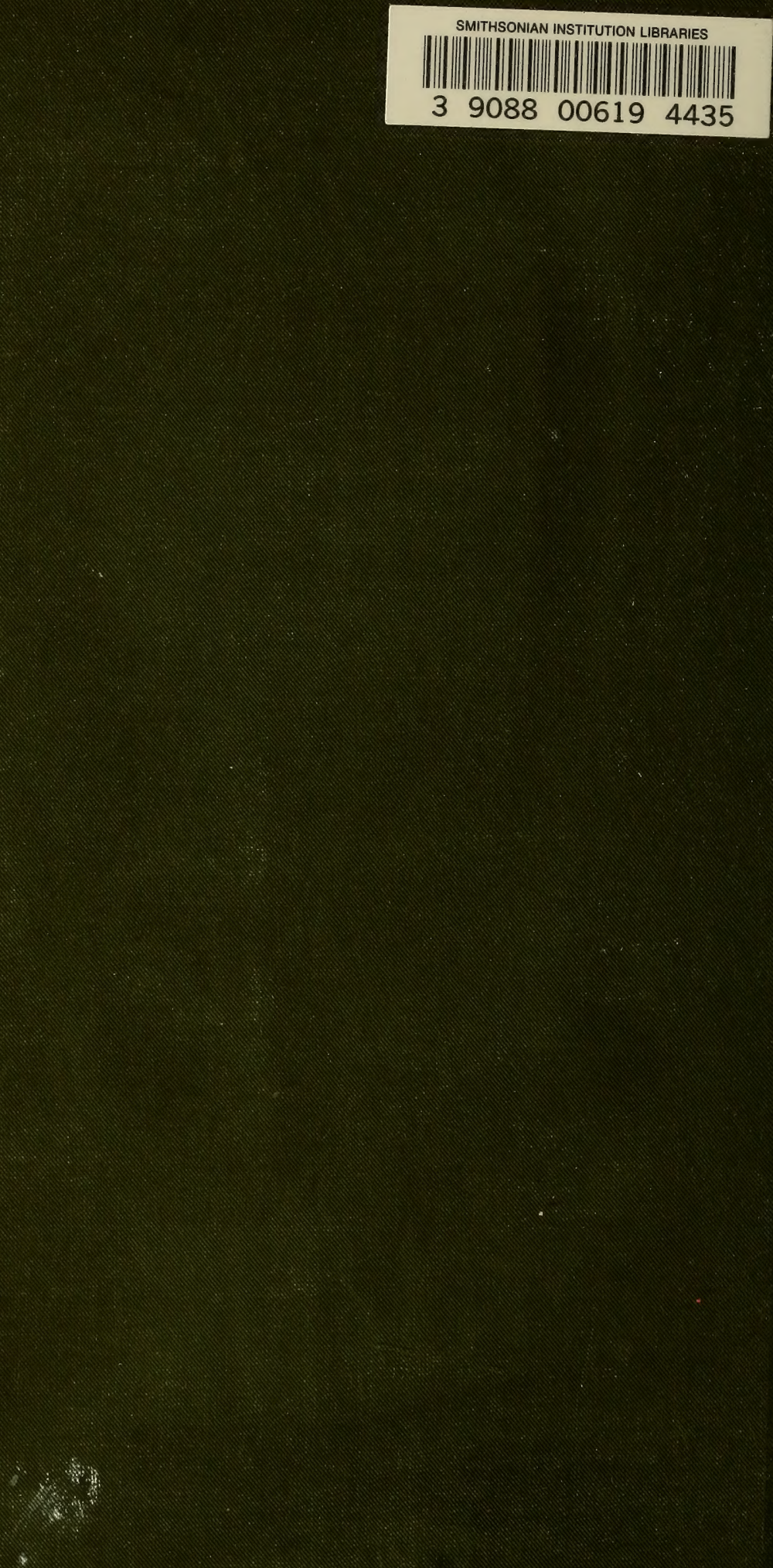